\title{
Jesuit Schools and Universities in Europe 1548-1773
}

\author{
Paul F. Grendler \\ University of Toronto, Emeritus \\ paulgrendler@gmail.com
}

\begin{abstract}
Paul F. Grendler, noted historian of European education, surveys Jesuit schools and universities throughout Europe from the first school founded in 1548 to the suppression of the Society of Jesus in 1773 . The Jesuits were famed educators who founded and operated an international network of schools and universities that enrolled students from the age of eight or ten through doctoral studies. The essay analyzes the organization, curriculum, pedagogy, culture, financing, relations with civil authorities, enrollments, and social composition of students in Jesuit pre-university schools. Grendler then examines the different forms of Jesuit universities. The Jesuits did almost all the teaching in small collegiate universities that they governed. In large civic-Jesuit universities the Jesuits taught the humanities, philosophy, and theology, while lay professors taught law and medicine. The article provides examples ranging from the first Jesuit school in Messina, Sicily, to universities across Europe. It features a complete list of Jesuit schools in France.
\end{abstract}

\section{Keywords}

schools - universities - education - Jesuits - Europe - France - Italy - Germanspeaking lands - humanities - philosophy

\section{Part 1: Schools}

The Jesuits founded three schools in the 1540s. Although primacy claims have been advanced for all three, only the school founded in Messina, Sicily, became the model for all future Jesuit schools in Europe. 


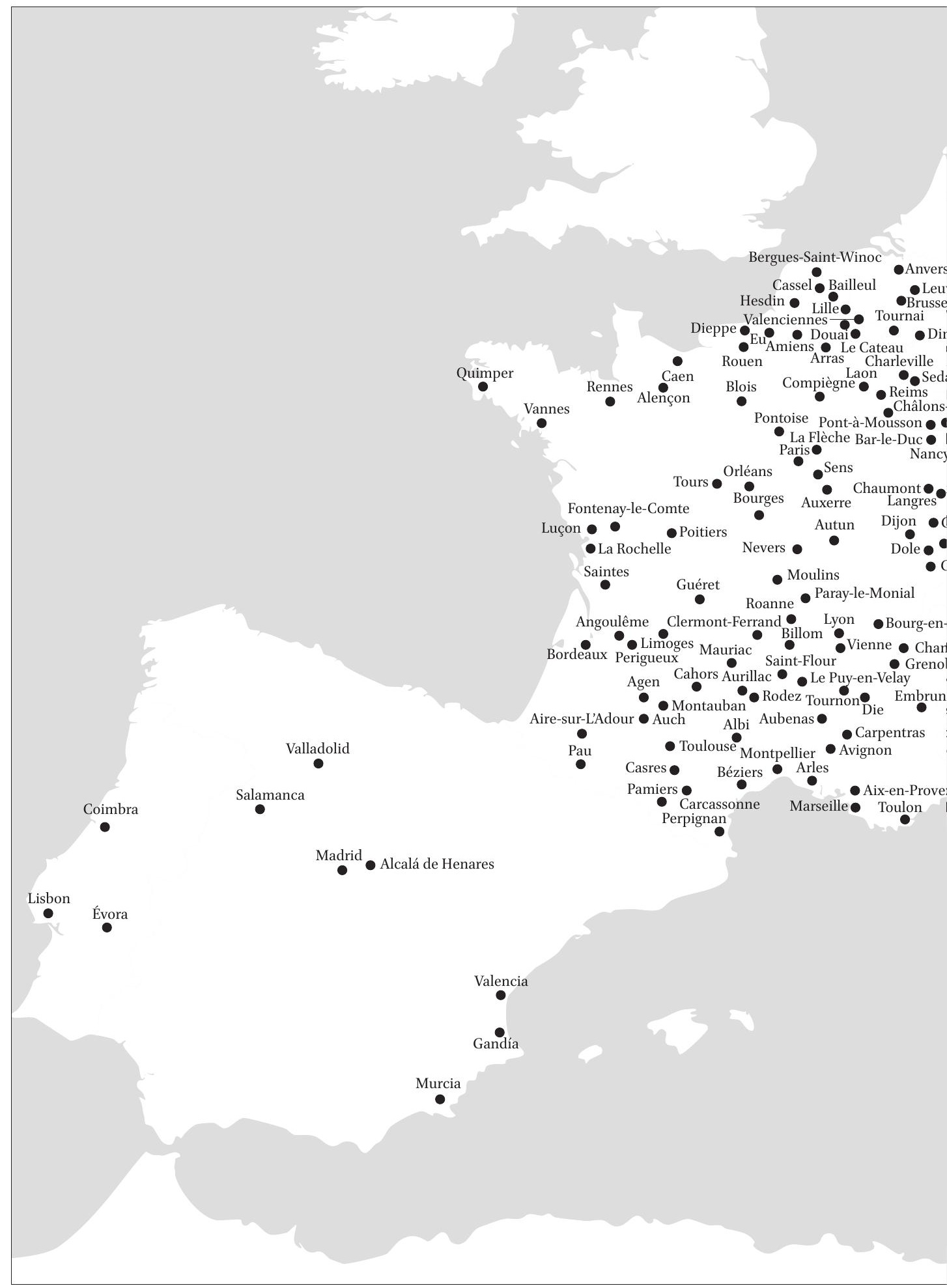


Osnabrück

Braniewo

Paderborn

-Anvers

- Leuven

Brussel

- Dinant

arleville

$\underset{ }{0}$ Sedan

Reims

Châlons-sur-Marne

usson $\bullet$ Verdun

le-Duc Metz $\bullet$ Bouquenom

Nancy $\bullet$ Saint-Nicolas-de-Port

Épinal ๑ OStrasbourg imont Langres Vesoul Colmar Dijon -Gray Ensisheim Besançon

- Chalon-sur-Saône

onial

Bourg-en-Bresse La Roche

- Grenoble Vercelli ${ }^{\bullet}$ Milan Brescia

elay

Embr
$n$

-en-Provence Coulon
Breslau (Wrocław)

Prague
Kraków

Olomouc (Olmütz)
Nagyszombat (Trnava)

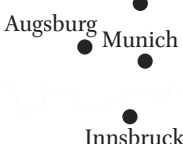

Innsbruck

\section{Vienna}

Graz

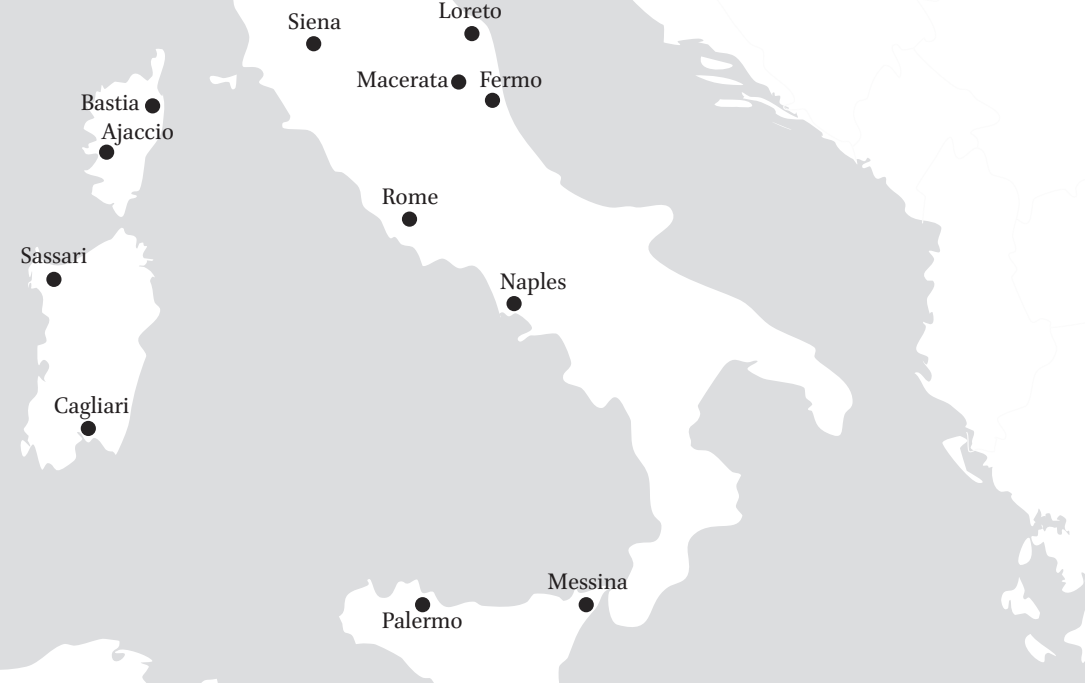


In 1541, representatives of the Portuguese bishop of Goa and the Portuguese governor of India decided to create a school to house and educate a small number of Indian boys for the priesthood. They asked the Franciscans to teach and govern the school, but they declined. By contrast, Francis Xavier (1506-52) was enthusiastic. At the end of 1543 , he designated a single Jesuit to teach Latin grammar and administer to the spiritual needs of the boys. A second Jesuit teacher was added in 1545, at which time the school had about sixty students ranging in age from seven to twenty-one. But the Jesuits did not take control of the school until 1548. Then came a crisis, as the first Jesuit rector dismissed most of the Asian students and replaced them with Portuguese boys. His policy was soon reversed, Asian boys returned, and in the 1550 s the school grew to three hundred and more students in two streams. A minority of students, many of whom became priests, received an intense Latin humanistic, philosophical, and theological education almost identical to what boys and youths in European Jesuit schools received. The majority of boys received a basic education in reading, writing, and arithmetic mostly in the vernacular. Some students boarded, while the majority were day students; both Jesuits and non-Jesuits taught. Over time, the Goa school became a seminary that trained priests for the entire Orient, and a general education school for local boys. ${ }^{1}$

However, the Goa school did not serve as a model and had little or no influence on Jesuit education in Europe for reasons of distance and chronology. There was limited communication about schools between Asia and Europe because travel was difficult and very slow. A Jesuit or a letter between East Asia and Europe needed to travel six months each way in order to reach a given destination. And both humans and letters were subject to shipwreck and other disasters. Second, the major development of the Goa school came in the $1550 \mathrm{~s}$ after European schools were established. Indeed, Goa's Latin curriculum imitated that of Messina, the Collegio Romano (Roman College), and other European Jesuit schools already established. In addition, the Goa school taught arithmetic in the vernacular, which European Jesuit schools did not do.

The next attempt came in 1545 . Francisco de Borja (1510-72, in office $15^{6} 5^{-}$ 72), the duke of Gandía and not yet a Jesuit, invited a few Jesuits to come to Gandía, a Spanish town that was the capital of the hereditary lands of the Borja family, to establish a Jesuit college and school. A handful of Jesuits taught Jesuit scholastics (that is, Jesuits studying and not yet ordained) and, at the request

1 Joseph Velinkar, "Jesuit Educational Style in Sixteenth-Century Goa," Divyadaan 13, no. 1 (2002): 59-72. See also the comments of Ricardo García Villoslada, Sant'Ignazio di Loyola, traduzione dallo spagnolo di Anna Maria Ercoles (Milan: Edizioni Paoline, 1990), 973-76. 
of Borja, also taught the sons of his converted Muslim subjects. ${ }^{2}$ Borja wished to raise the tiny Gandía school to a university. So, Ignatius of Loyola (c.14911556) persuaded Pope Paul III (1468-1549, r.1534-49) to issue a bull raising it to a university in 1547 . But Gandía was little more than a paper university, that is, an institution that had the authority to confer degrees but did little or no teaching. When Borja became a Jesuit in 1548 and moved to Rome in 1550, both the school and university at Gandía declined greatly. ${ }^{3}$ The Gandía school was barely a school, let alone a university.

The school at Messina was the true beginning of Jesuit education. On December 17 and 19, 1547, the Senate of Messina, with the warm endorsement of the Spanish viceroy (because Spain ruled Sicily), sent two letters asking Ignatius to establish a school in Messina to teach lay boys, that is, boys not intending to become clergymen. The city promised to provide a residence for the Jesuits, a church, and annual income of five hundred scudi, a significant but not overly generous sum. Ignatius accepted the invitation in a letter of January 14, 1548.4

Messina was an astonishing place for a new religious order to found its first school. The Jesuits already had colleges without schools in the major Italian cities of Rome, Padua, and Bologna, plus Alcalá de Henares, Coimbra, Cologne, Lisbon, Leuven, Paris, and Valencia in the rest of Europe. All of these other towns seemed to offer greater potential. And if the leadership of the Society, which was almost exclusively Spanish at this time, wanted to found the first Jesuit school in an Italian city ruled by Spain, Milan and Naples were more attractive. Messina was distant and separated from the rest of Italy by the perilous Straits of Messina.

The reason for Messina was that both Ignatius and the Messina Senate expected that a Jesuit college and school in Messina would quickly become a civic-Jesuit University of Messina that would educate both young Jesuits and non-Jesuits. ${ }^{5}$ The university did not happen. Although the Jesuit leadership and Senate of Messina argued and negotiated for fifty years over finances and

2 Mary Elizabeth Perry, "El legado de Francisco de Borja en las escuelas para niños moriscos," in Francisco de Borja y su tiempo: Política, religión y cultura en la edad moderna, ed. Enrique García Hernán and María del Pilar Ryan (Valencia: Albatros Ediciones, 2011), 6o9-17.

3 Paul F. Grendler, The Jesuits and Italian Universities 1548-1773 (Washington, DC: Catholic University of America Press, 2017), 43.

4 Allan P. Farrell, The Jesuit Code of Liberal Education: Development and Scope of the Ratio studiorum (Milwaukee: Bruce Publishing Company, 1938), 25-27; Daniela Novarese, Istituzioni politiche e studi di diritto fra Cinque e Seicento: Il Messanense Studium Generale tra politica gesuitica e istanze egemoniche cittadine (Milan: A. Giuffrè Editore, 1994), 29-37; and Grendler, Jesuits and Italian Universities, $37-38$.

5 Novarese, Istituzioni politiche, 28-6o; and Grendler, Jesuits and Italian Universities, 39-42. 
governance of the proposed university, they could not agree. ${ }^{6}$ But the Jesuits did establish a thriving school in Messina.

On March 18, 1548, Loyola dispatched by sea a group of ten (four priests and six scholastics) very able Jesuits, including Jerónimo Nadal (1507-80) and Peter Canisius (1521-97) to Messina. They arrived on April 8 and had a school up and running on April 18. But after a month or two it closed because of the heat. It reopened on October 1, 1548, with seven classes: lower Latin grammar, middle Latin grammar, higher Latin grammar, rhetoric, logic, Greek, and Hebrew (taught by Nadal). ${ }^{7}$ All instruction was free and enrollment was large, especially in the grammar classes. The Messina school was the model for all subsequent Jesuit schools. Its curriculum led to the Ratio studiorum of 1599. The educational treatises that Nadal and other Jesuits who taught in Messina wrote greatly influenced future Jesuit education. And several of the Jesuits sent to Messina became important scholars, teachers, and academic administrators in the Society.

The Messina school and the attempt to establish a university cast the die for the future, as the Jesuits established both pre-university schools and universities across Europe. Nevertheless, it is very unlikely that Loyola or any other Jesuit could have predicted that the Society would establish the largest and most important network of schools and universities in Europe before nation states created state systems of public education beginning in the late eighteenth and especially in the nineteenth centuries.

The attempt of the Jesuits and the Senate of Messina to create both a school and a university shapes the structure of this essay. Part 1 discusses schools. It describes major features of Jesuit schools with illustrative examples. Part 2 discusses universities. The Jesuits created and ruled new universities, or shared teaching and governance with others in existing universities, in several different ways.

\section{$2 \quad$ Basic Bibliography and Organization}

The ideal way to study Jesuit education would be to examine Jesuit schools and universities country-by-country, language-area-by-language-area, and school-by-school, because each political state, linguistic area, and school was unique. That is not possible here. Nevertheless, about 125 years ago the Society initiated a program of historical scholarship that aimed in this direction. While

6 Novarese, Istituzioni politiche; and Grendler, Jesuits and Italian Universities, 37-94.

7 Farrell, Jesuit Code, 27-29; Novarese, Istituzioni politiche, 42; and Grendler, Jesuits and Italian Universities, 40-41. 
not fully realized, it produced some very useful scholarship that is the starting point for studying Jesuit schools and universities before 1773 .

In its Twenty-Fourth General Congregation that met in 1892, the Society passed a decree strongly recommending to the new superior general "a continuation of writing the history of the Society." Although the Jesuits had recently begun a program of editing and publishing documents concerning the origins and first years of the Society, of which the first volume appeared in 1894, no major narrative histories written by Jesuits had appeared since the eighteenth century. The new superior general, Luis Martín (1846-1906, in office 1892-1906), strongly encouraged Jesuits to write narrative histories of the Society that would meet the highest standards of objectivity and the use of original sources. The effort produced rich results.

In the first half of the twentieth century, some learned and indefatigable Jesuits produced several multi-volume histories of the assistancies of the Society. (An assistancy is a large geographical area comprising several Jesuit provinces, most of whose inhabitants speak a common language. There were four assistancies [Italy, Germany, Portugal, and Spain] in 160o. The assistancy of France was added in 1608, and Poland and Lithuania in 1755.) These histories usually begin with the founding of the Society, then move to the arrival of the Jesuits in an assistancy. They narrate the history of the foundations of the first colleges in the assistancy, followed by the rest of the history of the Society in that assistancy until the suppressions. Along the way, these histories offer information on many individual Jesuit schools and universities. While the abbreviated notes in this survey emphasize more recent scholarship when it exists, the older histories remain essential for the study of Jesuit schools and universities in Europe.

For German-speaking lands, Bernhard Duhr, Geschichte der Jesuiten in den Ländern deutscher Zunge, 4 vols. in 6 parts (Freiburg im Breisgau: Herder, 190728 ), is a storehouse of information. It also contains material on eastern Europe, because the Austrian Habsburgs ruled part of eastern Europe. For Spain, see Antonio Astrain, Historia de la Compañía de Jesús en la asistencia de España, 7 vols. (Madrid: Administración de Razón y Fe, 1912-25). This work also has considerable material on the Spanish missions. For Portugal, see Francisco Rodrigues, História da Companhia de Jesus na assistência da Portugal, 4 vols. in 7 parts (Porto: Apostolado da Imprensa, 1931-50). It also contains considerable information on Portuguese missions to Asia and South America.

8 For Matters of Greater Moment: The First Thirty Jesuit Congregations; A Brief History and a Translation of the Decrees, ed. and trans. John W. Padberg, Martin D. O'Keefe, and John L. McCarthy (St. Louis: Institute of Jesuit Sources, 1994), 487. 
For France, start with Henri Fouqueray, Histoire de Compagnie de Jésus en France des origines à la suppression (1528-1762), 5 vols. (Paris: Bureaux des Études, 1910-25). Despite the title, it ends about 1645 because Fouqueray died in 1927. Very comprehensive and useful for the study of Jesuit education is Les établissements des jésuites en France depuis quatre siècles: Répertoire topo-bibliographique publié à l'occasion du quatrième centenaire de la fondation de la Compagnie de Jésus, 1540-1940, edited by Pierre Delattre, 5 vols. (Enghien: Institut supérieur de théologie, 1949-57). This is an encyclopedia (approximately 3,6oo folio-sized double columned pages) of articles on Jesuit activities in every town in France in which they founded a college or residence from their arrival in France until the 1940s. It includes towns added to the French monarchy through military conquest, such as Strasbourg, plus subject topics. Delattre wrote many of the articles and they are uniformly good. For the Low Countries, see Alfred Poncelet, Histoire de la Compagnie de Jésus dans les anciens Pays-Bas: Établissement de la Compagnie de Jésus en Belgique et ses développements jusquà la fin du règne d'Albert et d'Isabelle, 2 vols. (Brussels: Académie royale de Belgique, 1927-28). However, it covers only the period 1542 to 1621.

Two Jesuits have written a very detailed history of the Society in Italy but only through 1572. Pietro Tacchi Venturi, Storia della Compagnia di Gesù in Italia, 2 vols. in 4 parts (Rome: Civiltà Cattolica, 1910-51), is somewhat mistitled. Volume 1 in 2 parts provides an excellent religious history of Italy for the first half of the sixteenth century without mentioning Ignatius of Loyola or the Jesuits. Volume 2 in 2 parts begins with a biography of Loyola and narrates the history of the Society in Italy to 1556 . After a long hiatus, Mario Scaduto continued the history of the Society in Italy with volumes 3, 4, and 5 . These are usually cited by their individual titles as follows: Mario Scaduto, L'epoca di Giacomo Lainez 1556-1565: Il governo (Rome: La Civiltà Cattolica, 1964); L'epoca di Giacomo Lainez, 1556-1565: L'azione (Rome: La Civiltà Cattolica, 1974); and L'opera di Francesco Borgia, 1565-1572 (Rome: La Civiltà Cattolica, 1992). Tacchi Venturi and Scaduto provide a great deal of information on the early decades of the schools in Italy. The lay historian Sabina Pavone, "I gesuiti in Italia (15481773)," in Atlante della letteratura italiana, vol. 2, Dalla Controriforma alla Restaurazione, edited by Erminia Irace, 359-73 (Turin: Einaudi, 2011), provides a useful list of all Italian Jesuit houses with their foundation dates. The Mercurian Project: Forming Jesuit Culture 1573-1580, edited by Thomas M. McCoog (Rome: Institutum Historicum Societatis Iesu, 2004), provides information on Jesuit schools throughout Europe in the 1570 . Alessandro Monti, La Compagnia di Gesù nel territorio della provincia torinese, 2 vols. (Chieri: M. Ghirardi, 1914-15), provides excellent detailed chapters on individual colleges and their schools in the duchy of Piedmont-Savoy from their foundations to the suppressions. 
The articles on the Society in assistancies and political states in the Diccionario histórico de la Compagnia de Jesús: Biográfico-temático, edited by Charles E. O'Neill and Joaquín M. ${ }^{a}$ Domínguez, 4 vols. (Rome: Institutum Historicum S.I., 2001 [henceforth, $D H C J$ ]), provide summary accounts and some bibliography on Jesuit schools in these states.

It is often difficult to compile a list of all Jesuit colleges in an assistancy or province at a given date. Three works aid in this endeavor. Alfred Hamy, Documents pour servir à l'histoire des domiciles de la Compagnie de Jésus dans le monde entier de 1540 a 1773 (Paris: Alphonse Picard, 1892), provides lists of Jesuit houses in all the provinces, plus vernacular versions of Latin place names. A photographic reproduction of documents that list all the Jesuit houses across the world in 1626 and 1640 plus additional information is found in Art, Controversy, and the Jesuits: The Imago primi saeculi (1640), edited by John W. O'Malley (Philadelphia: Saint Joseph's University Press, 2015), 707-18.

Some of the 166 volumes (1894 through 2014) of the Monumenta Historica Societatis Iesu publish the letters and other documents of the first Jesuits and these are full of comments about the foundations of Jesuit schools. For the history of Jesuit education, the most important and useful of the Monumenta series is the Monumenta paedagogica Societatis Iesu, nova editio ex integro refecta, edited by László Lukács, 7 vols. (Rome: Apud "Monumenta Historica Soc. Iesu," 1965-92 [henceforth Mon. paed., nova editio]). The volumes offer about seven thousand pages of educational documents for the period 1540 through 1616. A few well-selected documents from the Monumenta paedagogica have been translated into English in Jesuit Pedagogy, 1540-1616: A Reader, edited by Cristiano Casalini and Claude Pavur (Chestnut Hill, MA: Institute of Jesuit Sources, 2016). In addition, the seventy-six volumes (through 2015) of the Biblioteca Instituti Historici Societatis Iesu include both historical monographs and volumes with multiple authors, among which information about schools is scattered. Since all the references in this section are given in full here, and again in the end bibliography, citations to the above volumes in the footnotes will be brief.

While the assistancy histories written by Jesuits have come to an end, non-Jesuit historians have published a number of general histories that contain a good deal of information about Jesuit schools. The most recent and most useful is Markus Friedrich, Die Jesuiten: Aufstieg Niedergang Neubeginn (Munich: Piper, 2016). The current preference is collaborative histories, several of which are cited in this article. Worthy of mention is The Cambridge Encyclopedia of the Jesuits, general editor Thomas Worcester (Cambridge: Cambridge University Press, 2017), with introductions and limited bibliography on many aspects of Jesuit history. 


\section{$3 \quad$ The Schools Are the Most Important Ministry}

By his actions, Ignatius of Loyola determined that teaching would be the major ministry of the Society. But he did not provide a plan enabling the Jesuits to accomplish this. Instead, when he died on July 31,1556 , he bequeathed to the Society forty-six schools and a crippling teacher shortage. His successor, Diego Laínez (1512-65; vicar general 1556-58; superior general 1558-65), first tried to cope with the lack of teachers through ill-advised expedients. He then devised the solution. On August 10, 1560, Juan Alfonso de Polanco (1517-76), writing for Laínez, sent a letter to all the superiors of the Society. Laínez announced that education was the most important ministry of the Society, equal to all the other ministries combined. And he decreed that every Jesuit must ordinarily "bear part of the burden of the schools." 9 That is, all Jesuits would teach. By all Jesuits, he meant priests and those studying to be priests. Jesuit brothers (temporal coadjutors) who did the mundane tasks of cooking, cleaning, and maintaining the Society's buildings and churches would not teach because they were not Latin-literate. The policy was implemented without any known objection, which meant that the first generation of Jesuits had already tacitly accepted that the Jesuits would be a teaching order. ${ }^{10}$

Laínez's decision determined the career paths of Jesuits in the presuppression period and forever shaped the Society. ${ }^{11}$ A typical Jesuit entered the Society at the age of sixteen, seventeen, or eighteen, sometimes older, rarely younger. He spent two years as a novice. After the novitiate, if the young Jesuit was not well prepared in Latin and Greek, he spent a year or two improving his skills. If he was well prepared, he immediately began three years of philosophical studies consisting of one year of logic, a second year of natural philosophy, and a third year of metaphysics, based on the appropriate texts of Aristotle. Now aged twenty-three to twenty-five, he spent the next three to five years teaching Latin grammar, the humanities, and/or rhetoric in a Jesuit lower school. For some Jesuits, the three to five years of lower school teaching was the extent of their teaching. After teaching in a lower school, all Jesuits

"Et così essendovi, generalmente parlando, due maniere di aiutar li prossimi: una nelli collegii con la institutione della gioventù nelle lettere, dottrina et vita christiana; l'altra con aiutar universalmente tutti con le prediche et confessioni, et altri mezzi conformi al nostro solito modo di procedere." "Che tutti ordinariamente doveranno portar parte del peso delle schuole"; Mon. paed., nova editio, 3:304-6, quotes on 305. Paul F. Grendler, “The Culture of the Jesuit Teacher 1548-1773," Journal of Jesuit Studies 3, no. 1 (2016): 18-25.

11 John O'Malley was the first historian to recognize the extraordinary importance of Laínez's action. John W. O'Malley, The First Jesuits (Cambridge, MA: Harvard University Press, 1993), 200-1. 
intended for the priesthood studied theology for four years and were ordained, often at the end of the third year. After ordination and completion of theological studies, the majority of European Jesuits went on to other careers, such as preaching, hearing confessions, missions to the countryside and remote parts of Europe, ministering to the ill, or administrative duties.

A modest number of Jesuit priests began to teach philosophy, because fewer philosophy teachers than lower-school teachers were needed. A Jesuit normally taught logic, natural philosophy, and metaphysics one after the other in a three-year cycle. He might do this for three or six years or for many years. After teaching philosophy for a short time, the ablest scholars were advanced to teaching theology. A handful of Jesuits considered the leading scholars of the Society, men such as Francisco Suárez (1548-1617), then taught theology for the rest of their lives. But very few Jesuits spent their entire lives teaching, because Laínez had not forgotten the other ministries. Every few years, a Jesuit career teacher was assigned a different task, such as rector of a college, or prefect of studies, or whatever else needed to be done, for one to three years. ${ }^{12}$

Although it took decades, Laínez's decree solved the teacher shortage and guaranteed a steady supply of teachers. General and provincial superiors were able to plan ahead. They knew when and where they would be able to found new schools and add classes to existing ones, because they could estimate how many lower-school and upper-school teachers would be available.

And more Jesuits meant more teachers. In 1581, there were 5,165 Jesuits worldwide; in 1600 , there were 8,519 ; at the end of 1615 , there were 13,112 Jesuits. $^{13}$ Europe provided a great deal of the increase. This extraordinary growth spurt, especially in the first fifteen years of the seventeenth century, made possible the founding of many new schools and adding classes to existing schools. Membership growth then slowed. The Society added another two thousand members between 1615 and 1625 , still a very substantial number. But they added only another two thousand from 1626 through $1675 \cdot{ }^{14}$ There were several reasons. The Thirty Years' War (1618-48) produced great human and economic suffering in central Europe. The plague of 1630 to 1633 , centered in Italy, cost many lives. The Spanish economy steadily declined. And perhaps the attraction of the Society as the leader in the struggle to restore Catholicism in

12 This is based on many biographies, especially of Italian Jesuits, in $D H C J$; numerous annual, triennial, and quadrennial catalogs in ARSI; and secondary scholarship.

13 Pierre Delattre, "Introduction," in Les établissements en France, 1:i-xvi, here 1:ii; William V. Bangert, A History of the Society of Jesus, 2nd ed. (St. Louis: Institute of Jesuit Sources, 1986), 179; and Mario Fois, "Aquaviva, Claudio," DHCJ, 2:1616.

14 Bangert, History, 179; Padberg, O'Keefe, and McCarthy, For Matters of Greater Moment, 20; and Mario Fois, "Vitelleschi, Mucio [Muzio]," DHcJ, 2:1623. 
Protestant lands slackened. Jesuit general congregations and generals became more cautious: they told provinces not to accept more novices than they could support physically and educate well.

\section{$4 \quad$ College and School}

In the 1560 s and 1570s, a common organizational pattern of Jesuit schools in Europe and their financial support emerged. The basic Jesuit school was a municipal day school teaching the Latin curriculum. The students lived at home, came to school for about two-and-one-half hours in the morning plus daily Mass, went home for lunch, returned for another two-and-one-half hours of classes and/or other activities in the afternoon, then returned home to sleep under the parental roof. A Jesuit day school was part of a Jesuit college, and the college and its school received financial support from the local civil government.

The most important unit of the Society in Europe was the college, defined as an established community of Jesuits in a town. ${ }^{15}$ In 1558 , the First General Congregation decreed a definition and minimum requirements for a college. It had to have a church owned by the Jesuits or set aside by the papacy for their exclusive use, a suitable residence for the Jesuits, another building for a school, and secure financial support, preferably an endowment, sufficient to support fourteen Jesuits. ${ }^{16}$ The Jesuits followed this formula except for the fourteen-Jesuit minimum, which they routinely ignored by founding many colleges whose number of Jesuits never reached that figure.

The bulk of most endowments commonly came from properties assigned to the local Jesuit college by the civil ruler, that is, the king, prince, duke, or city council. ${ }^{17}$ And the ruler or city council often paid "startup costs" as well, by providing a building, or paying the cost of renovating a building to serve as a residence or school. Income from other sources, such as a private donor or a legacy, often supplemented the state contribution. Local bishops sometimes provided money or diverted benefice income to the Jesuits, although the

15 What follows is a short pragmatic analysis of the relationship of college, school, and residence. For more extended discussions, see Pierre Delattre, "Introduction," vii-xii; and Ignacio Echarte, "Casas," $D H C J, 1: 678-87$.

16 Padberg, O'Keefe, and McCarthy, For Matters of Greater Moment, 86-87, decree 73 after the election.

17 The following discussion is based on my research into the foundations of numerous Italian colleges in ARSI, published studies of individual colleges, and the studies in I patrimoni dei gesuiti nell'Italia moderna: Una prospettiva comparativa, a cura di Niccolò Guasti (Bari: Edipuglia, 2013). For foundations outside of Italy, I have relied on the assistancy histories. 
sums were seldom large. ${ }^{18}$ Nevertheless, the major part of endowments almost always came from civil governments, which meant from revenues gathered through taxes.

A college was not a school, even though the Jesuits at the time and many historians since use the words interchangeably. At the same time, most European colleges had schools. And the schools were normally joint civic-Jesuit enterprises. In addition to the initial endowment and/or start-up support, a school almost always depended on annual financial support from the local civil government. It was a legal arrangement, because the two parties signed a contract. A town agreed to pay the local Jesuit college for its educational and religious services. The college promised to open and staff a school with a designated number of classes teaching specific subjects, in return for an annual monetary payment. Contracts often contained penalty clauses, such as the town would pay the Jesuits less if they did not teach all the contracted classes, or the Jesuits would drop a class if the town decreased its payments. The town consigned governance of the school and selection of Jesuit teachers, textbooks, and pedagogy to the Jesuits. Contracts usually were limited to a number of years, but were renewable indefinitely. The result was that Jesuit schools were almost always semi-public schools, meaning that they were state-supported. They were also public because they were free of charge and open to all male students who passed an entrance examination. Until other religious orders also began to teach lay students in significant numbers in the seventeenth and eighteenth centuries, the Jesuit school was almost always the only public school in a town. Other teachers were private teachers paid by parents.

A major reason for contracted semi-public schools was the Jesuit Constitutions, which barred individual Jesuits from accepting salaries for teaching or payment from students. Payment from the town went to the local Jesuit college to be used at its discretion to support all of its ministries in the town. It is likely that the town and the local Jesuits saw the payment differently. The town viewed it primarily as payment for Jesuit teaching. The Jesuits saw it as support for all their ministries, which included celebrating Mass, administering the sacraments, preaching, catechetical instruction for boys, girls and adults not attending the Jesuit school, ministering to the sick and dying, providing a confessor for the ruler and his family, missions to the countryside, maintenance of the church, school, and residence, food and lodging for the Jesuits, and anything else that the Jesuits decided to do.

18 An exception was when the bishop was also the prince (civil ruler) of a little state, as was sometimes the case in central Europe. As civil ruler, he enjoyed much greater revenues than an ordinary bishop, which he could direct to the Jesuits. 
A few Jesuit residences also had schools. A Jesuit residence was an initial Jesuit establishment that might become a college. A small group of Jesuits came to a town on a tentative basis, hoping that their presence would attract the necessary financial and popular support to become a college. Starting a school was one way to attract more support and it sometimes worked. If not, the Jesuits abandoned the town. In a handful of cases across Europe, the Jesuits established a residence with a small school that was unable to grow into a college but, nevertheless, endured until the suppression.

\section{$5 \quad$ Jesuit Islands}

Ignatius of Loyola directed his fellow Jesuits to pay close attention to locating their colleges. He wanted the Jesuits to choose a good site, to acquire a property large enough for college and church, and to make sure that there was room to expand. If possible, the college should be situated in the center of the city, not far from "the conversation of the city," as he expressed it. He recommended buying, not renting. ${ }^{19}$

The Jesuits followed Ignatius's instruction. They tried to group their several buildings into a contiguous group near the center of a city or town. Church, Jesuit residence, school, and boarding school, if there was one, were clustered together. With the permission of the city council, the Jesuits closed streets in order to render the complex more homogeneous. Moreover, the Jesuits were often able to expand their establishments by replacing the modest church assigned to them with a grander structure. Or they added more classrooms or a library to the school. Contemporaries called these urban complexes "Jesuit islands," meaning several contiguous or closely linked buildings used exclusively by the Jesuits. ${ }^{20}$ Jesuit islands were major features of cities. Three examples

19 "Habiasi cura speciale che si pigi un sito buono et largo assai, o che si possa questo slargare col tempo, che basti per casa et chiesa; et se si può, non troppo discosto da la conversatione della città; et comprato quello, saria buono principio del resto." Letter of Loyola to Father Jean Pelletier at Ferrara, June 13, 1551, in Sancti Ignatii de Loyola Societatis Jesu fundatoris epistolae et instructiones, vol. 3, 1550-1551, ed. Vicente Agustí, Federico Cervós, and Mariano Lecina (Madrid: Typis Gabrielis López del Horno, 1905), 542-50 (quote 548). This was a general directive written at the moment that Ignatius realized that colleges with schools were going to be the major ministry of the Society in Europe. Thomas M. Lucas, Landmarking: City, Church \& Jesuit Urban Strategy (Chicago: Loyola Press, 1997), 199-203, provides an English translation.

20 For example, see the comments of Giuseppe Gorzoni (1637-1713) who wrote a history of the Jesuits in Mantua. When the Jesuits purchased the last house to complete their island in Mantua in 1602, he wrote "Era questa casa unica che restasse nella nostra isola di mezzo [...]."; and "E finalmente del 1602 tutta la casa fu nostra e nostra tutta fu la sopra detta isola" [This was the only house that remained in the middle of our island. In 16o2, the entire 
were the Jesuit islands in Bologna, Mantua, and Prague, whose centerpiece was the huge College of St. Clement. ${ }^{21}$

Today, the Jesuit islands are gone. After the suppressions of the 1760 s and 1770s, plus further anti-religious actions in the French Revolution and in lands conquered by France during the Napoleonic era, Jesuit buildings and churches were put to other purposes. When the Society was reconstituted in 1814, they were seldom restored to the Society. Instead, they were bought and sold repeatedly, and so extensively renovated for other purposes, that the Jesuit islands are very difficult to visualize today.

\section{The Curriculum}

Fifty years of teaching, much experimentation, numerous treatises on education, several committees, and two draft plans culminated in the Ratio atque institutio studiorum Societatis Iesu (The official plan for Jesuit education), usually called Ratio studiorum (Plan of studies), of 1599. Jesuit schools and universities followed it until the suppression, and returned to it in slightly modified form in the nineteenth century.

The complete Jesuit course of studies had three ascending parts intended for three different student constituencies. At the same time, it was a remarkably unified and coherent plan of studies that Jesuits believed enabled everyone to learn. The first part was the lower school, which taught the standard Renaissance humanistic studies curriculum based on the Latin and, to a lesser extent, Greek classics. Fifteenth-century Italian pedagogical humanists created this curriculum, which won over northern Europe in the first quarter of the sixteenth century. The University of Paris had just completed its transition from a medieval grammar and rhetoric curriculum to the Renaissance humanities curriculum when the ten first Jesuits arrived between 1525 and 1534. The Jesuits taught what they had learned.

house was finally ours and the entire said island]. Gorzoni wrote his chronicle between about 1700 and 1711. Giuseppe Gorzoni, Istoria del Collegio di Mantova della Compagnia di Giesù scritta dal padre Giuseppe Gorzoni: Parte prima, ed. Antonella Bilotto and Flavio Rurale (Mantua: Gianluigi Arcari Editore, 1997), ${ }_{36}^{6}-37,87$ (quotes). But this certainly was not the first use of the term "isola" or "isolata" to describe Jesuit urban complexes.

21 On the Bologna island, see Dall'isola alla città: I gesuiti a Bologna, a cura di Gian Paolo Brizzi e Anna Maria Matteucci (Bologna: Nuova Alfa Editoriale, 1988). On the Mantua island, see Il palazzo degli studi: Appunti per una storia dell'istruzione superiore a Mantova; Luoghi e vicende dal Collegio dei gesuiti al Liceo Ginnasio “Virgilio," ed. Ugo Bazzotti and Daniela Ferrari, 2nd ed. (Mantua: Publi-Paolini Editore, 1998); and Paul F. Grendler, The University of Mantua, the Gonzaga \& the Jesuits, 1584-1630 (Baltimore: Johns Hopkins University Press, 2009), 33-37, 248-49. For the College of St. Clement, see Josef Koláĉek, "Colegio San Clemente de Praga," DHCJ, 1:852-53. 
Before entering a Jesuit school, a boy first had to be able to read and write and have learned a little Latin grammar. He was examined; if he passed, he entered the Jesuit school, often at the age of eight, nine, or ten.

There were five classes in the humanistic studies lower school Jesuit curriculum. The lowest grammar class consisted of intense drilling in Latin grammar with a focus on syntax and Latin prose. ${ }^{22}$ The two basic texts were Cicero's Epistulae ad familiares (Letters to his friends) and a grammar manual. Making Cicero's Epistulae ad familiares the text for teaching classical Latin prose was not unusual. Practically every Latin school, whether municipal, ecclesiastical, or independent, Catholic or Protestant, in Europe did the same. And Latin schools teach Cicero's letters today. The Ratio studiorum recommended the De institutione grammatica libri tres (Three books on the teaching of grammar; first published in 1572) of the Portuguese Jesuit Manoel Alvares (1526-82) as a grammar manual. The Ratio studiorum prescribed starting Greek, about forty-five minutes of instruction in the school day lasting five hours.

Just as important as Cicero were the relentless and highly organized combination of exposition of new material, grammar drills, recitations from memory, oral and written composition exercises, continuous review, and nightly homework (see "Pedagogical Techniques and Classroom Culture" below). Jesuit educational treatises frequently referred to the modus Parisiensis (the method of Paris) as their inspiration. They did not mean the classical authors per se, but learning the classics through relentless drills and exercises. The method of Paris meant a tight and orderly progression of studies that required students to master one grammatical element before proceeding to the next, learning well the material of the first half year of a class before advancing to the second half, and mastering the material of the lowest grammar class before promotion to the middle grammar class.

The instructions for the middle grammar and highest grammar classes were the same except that additional authors and books were read, the grammatical material was more complex, and more Greek reading and grammar were introduced. In the highest grammar class, the Ratio studiorum told the teacher to teach Cicero's Letters to Atticus, Letters to Quintus, On Friendship, On Old Age, and Paradoxes, as well as Letters to His Friends. This class also taught a full range of poets, including "some selected and expurgated elegies and letters of" Ovid, Catullus, Tibullus, Propertius, and the Eclogues of Virgil, plus the

22 The Ratio studiorum: The Official Plan for Jesuit Education, trans. and commentary by Claude Pavur (St. Louis: Institute of Jesuit Sources, 2005), paragraphs 425-33 plus the summary on pp. 228-29. Although there is a large bibliography on the Jesuit humanistic school, Farrell, Jesuit Code, is still excellent. 
"easier books" of Virgil, "such as the fourth book of the Georgics, the fifth and seventh books of Aeneid." For Greek, St. John Chrysostom, Aesop, and Agapetus were to be read. ${ }^{23}$

The humanities class taught the rules of rhetoric, ancient history, and some moral philosophy through examples, orations, and poetry. Prolonged study of De arte rhetorica libri tres (Three book on the art of rhetoric; first published in 1562) of the Portuguese Jesuit Cipriano Soares (1524-93) implanted the rules of rhetoric. New works taught included the orations of Cicero "that contain his moral philosophy," including Pro lege Manilia, Pro Archia, Pro Marcello, "and others delivered to Caesar," which meant his Pro Ligario and Pro Rege Deiotaro. The historians Caesar, Sallust (whose major works were Catiline's War and the Jugurthine War), Livy, and Alexander the Great of Quintus Curtius Rufus were taught. Not only did these books teach Roman and Greek political and military history; they also contained numerous examples of good and evil civic and personal actions, plus denunciations of tyrants and lawbreakers. They told readers to do good for its own sake and for the good of the state. There was more reading of Virgil's Aeneid and Eclogues, plus "select odes of Horace, and likewise, elegies, epigrams, and other poems of famous ancient poets, provided that they have been expurgated of everything indecent and offensive." The students were to compose poetic verses and to rewrite poems into another genre. The students were expected to write a little Greek, and the regimen of drills, recitations, review, and homework continued. ${ }^{24}$

The rhetoric class "aims at an education of perfect eloquence." The culmination of the Jesuit lower school, it sought to bring to a high degree of perfection the student's ability to speak and write eloquent classical Latin. The recommended texts were "Cicero's books on rhetoric and Aristotle's Rhetoric and Poetics." The parts of good persuasive composition was explained: invention, arrangement, "how skillfully the orator works himself into our good graces, how appropriately he speaks," and so on. The exercises included writing descriptive passages in different ways, fitting subject matter into rhetorical figures, and translating Latin to Greek and Greek to Latin. The works of Demosthenes, Plato, Thucydides, Homer, Hesiod, and Pindar, plus Saints Gregory Nazianzen, Basil, and John Chrysostom, were introduced. Rhetoric was seen as a performing art. Hence, one or two students regularly declaimed before the humanities and rhetoric classes or in a hall or church, and they performed in dramas. ${ }^{25}$

23 Ratio studiorum, paragraphs $405^{-24}$, quotes on p. 174.

24 Ratio studiorum, paragraphs 395-404, quotes on pp. 166, 167; see also pp. 232-34, 245.

25 Ratio studiorum, paragraphs 375-94, quote on p. 16o, plus pp. 234-35. 
Daily Mass attendance was obligatory, and students were expected to hear sermons and participate in religious ceremonies. ${ }^{26}$ On the other hand, the Ratio studiorum mandated little catechetical instruction: an hour and a half for the three grammar classes on Saturday, a half hour for the humanities class on Saturday, and none for the rhetoric class. ${ }^{27}$ And it did not prescribe a specific catechism; instead, the Ratio studiorum told Jesuit teachers to write catechisms and abridgments for local use: "Each week everyone should attend the catechism instruction and learn by heart the abridgement (compendium) that the teachers have drawn up for it." 28

In practice, the schools also used vernacular catechisms written by Jesuits. The Dottrina cristiana breve (Brief Christian doctrine; first published in Rome 1597), and the longer version for adults, Dichiarazione più copiosa della dottrina cristiana (More complete explanation of Christian doctrine; first published in Rome 1598) of Robert Bellarmine (1542-1621), were widely used in Italy. ${ }^{29}$ Jesuit schools in German-speaking lands preferred Peter Canisius's three catechisms of ascending size and complexity, originally written in Latin but often published in German. In addition, the catechisms of both Bellarmine and Canisius were translated into other languages, including Polish. ${ }^{30}$ Other Jesuits also wrote widely used vernacular catechisms. French Jesuit schools used Émond Auger's (1530-91) Catéchisme et sommaire de la religion chrestienne (Catechism and summary of the Christian religion; first published in Lyon 1563), which is a point-by-point refutation of Calvinism, and his Petit catéchisme et sommaire de la religion chrestienne (Little catechism and summary of the Christian religion; first published in Paris 1568). ${ }^{31}$ In the eighteenth century, Ignaz Parhamer (1715-86), a famed catechist and missionary within Europe, wrote German catechisms that were translated into Czech, Hungarian, and other languages. ${ }^{32}$

While the Ratio studiorum did not indicate whether catechetical instruction in Jesuit schools was to be conducted in Latin or the vernacular, the fact that many more vernacular than Latin editions of Jesuit catechisms are known suggests that vernacular catechesis was the norm. Catechetical instruction outside of school for boys, girls, and adults who lacked Latin had to be in the vernacular. Like all catechists in those centuries, the Jesuits expected students

26 Ratio studiorum, paragraphs 131, 295, 327, and 468.

27 Ratio studiorum, paragraphs 396, 406, 416, 426, and 469.

28 Ratio studiorum, paragraph 469, quote on p. 199.

29 An example comes from the Bologna day school in the 1670s. See Natale Fabrini, Un documento bolognese inedito su le scuole dei gesuiti (Rome: Stella Matutina, 1946), 48.

$30 \quad$ Ludwik Piechnik and Ludwik Grzebien, "Polonia," DHCJ, 4:3178.

31 John Patrick Donnelly, "Auger, Émond," $D H C J, 1: 268-69$.

32 Helmut Platzgummer, "Parhamer (Parhammer), Ignaz," DHCJ, 3:3044-45. 
to memorize and repeat all or most of the contents of catechisms. This could be done in the vernacular or Latin, so long as students understood the meaning of the words, which was the responsibility of the catechist.

The Ratio studiorum decreed that the school year should last ten to eleven and one-half months of the year, with higher classes enjoying longer vacations. But it did not prescribe when the academic year should begin. ${ }^{33}$ In Italy, the Jesuit academic year often began about October 1 and lasted through much of August. Classes met Monday through Saturday. However, numerous religious holidays interrupted the calendar. On those days, the students might come to school or church for a half day in order to march in processions, participate in liturgies or ceremonies, and/or hear sermons. When there was no religious holiday during the week, the Ratio studiorum recommended a "break day," usually Wednesday or Thursday, in which classes were cancelled or met only in the morning. ${ }^{34}$

\section{$7 \quad$ Jesuit Civic Humanism}

The vast majority of the students who attended the lower school were lay boys and youths. From 1551 to the eve of the suppressions, Jesuits repeatedly stated that the goal of the lower school was to educate these students to become able, eloquent, and virtuous leaders of civil society who would act for the common good. And if a boy decided to become a priest, he was being educated to act for the good of the Catholic Church. Jesuit schools aimed to prepare future leaders of state, society, and church by giving them a thorough education in the humanities based on the ancient classics plus religious training. This was Jesuit civic humanism. ${ }^{35}$

Jesuits repeatedly articulated this goal. On December 1, 1551, Juan Alfonso de Polanco, on commission from Ignatius of Loyola, wrote to the provincial superior for Spain a programmatic letter that explained and justified Jesuit education. The letter is notable for its pragmatic tone. Polanco gave fifteen reasons

33 Ratio studiorum, paragraphs 6o-66.

34 Ratio studiorum, paragraphs 69, 70, 72.

35 Hans Baron coined the term "civic humanism" in his famous book first published in 1955. See The Crisis of the Early Italian Renaissance: Civic Humanism and Republican Liberty in an Age of Classicism and Tyranny, revised one-volume edition with an epilogue (Princeton: Princeton University Press, 1966). Although Baron focused on the link between humanism and republicanism in Florence in the early fifteenth century, civic humanism came to mean studying the classics as preparation for leadership roles in civil society, whether the state was a republic, princedom, or monarchy. For further explanation, see Paul F. Grendler, Schooling in Renaissance Italy: Literacy and Learning, 1300-1600 (Baltimore: Johns Hopkins University Press, 1989), 125-42, and passim. This was the tradition that the Jesuits adopted for their own purposes. 
why a Jesuit education was useful to the Jesuits themselves, external students and their parents, and the people of the country or territory in which a Jesuit school was located. The last group emerged most clearly in the fifteenth benefit of a Jesuit education:

15. From among those who are at present only students, various persons will in time emerge-some for preaching and the care of souls, others for the government of the land and the administration of justice, and others for other responsibilities. In short, since young people turn into adults, their good formation in life and learning will benefit many others, with the fruit expanding more widely every day. ${ }^{36}$

Then in 1555, the Jesuits told the bishop of Murcia (in southeastern Spain) that teaching the humanistic curriculum would greatly benefit the "republic" by producing good priests, good senators, and good citizens of every status. ${ }^{37}$ It must have worked because, with the bishop's generous support, the school opened in $1555^{38}$ In 1564 and 1565 , Diego de Ledesma (c.1524-75), at that time prefect of studies at the Roman College, drafted a plan of studies for the Roman College, which became a semi-official plan of studies before adoption of the Ratio studiorum. Ledesma began with a justification of the humanistic studies part of Jesuit education. In a true Christian republic and in the church of Christ, he wrote, they were most necessary for several reasons. They offer many advantages for practical living. They contribute to the right government of public affairs and the proper making of laws. They ornament and give splendor and perfection to man's rational nature. And they support religion and guide us to our proper end with God. ${ }^{39}$

$3^{6}$ Ignatius of Loyola: Letters and Instructions, ed. Martin E. Palmer, John W. Padberg, and John L. McCarthy (St. Louis: Institute of Jesuit Sources, 2006), 363, and 360-63 for the whole letter. See also O'Malley, First Jesuits, 211-13.

37 "Et si nostri instituendae juventutis in litteris et virtutibus curam haberent, magnam reipublicae utilitatem inde consecuturam, cum ex his boni sacerdotes, et boni senatores, et omnium statuum cives essent egressuri." Vita Ignatii Loiolae et rerum Societatis Iesu historia auctore Joanne Alphonso de Polanco ejusdem Societatis sacerdote, vol. 5, 1555, ed. José M. Vélez (Madrid: Augustinus Avrial, 1897), 535, paragraph 1459; and O’Malley, First Jesuits, 212, who first noted this passage and translated senatores as "city officials." This is reasonable, because elected city magistrates were sometimes called senators whether or not it was the official name of the office.

38 Astrain, Historia, 2:437.

39 Mon. paed., nova editio, 2:528-29, lines 245-53. John W. Padberg, S.J., "Development of the Ratio studiorum," in The Jesuit Ratio studiorum: 4ooth Anniversary Perspectives, ed. Vincent J. Duminuco (New York: Fordham University Press, 2000), 98, points to the 
Jesuits continued to believe strongly that educating students who would be future leaders of society in humanist studies was an important goal of the Society. And when the Society appeared to slacken its efforts, concerned Jesuits spoke out. Fulvio Cardulo (1529-91) was a famed orator who taught rhetoric at the Roman College from 1553 to at least 1575 and possibly to the end of his life. In 1584, he addressed a fervent plea on the importance of a humanistic education for students who would be future leaders of society to a committee charged with preparing the Ratio studiorum. He began by saying that teaching the humanities was an enterprise undertaken by the Society for the honor of God and for "the universal help of the Christian state [repubblica christiana]." But the Jesuits had not been doing a very good job of it recently, in the judgment of princes, prelates, and judicious and learned men who love the Society, Cardulo wrote. He then offered a strong civic justification for teaching the humanities. The Society did not just teach Latin grammar and language, but had a higher aim, that of "molding political men useful for cities" (formare uomini politici et utili alle città). The goal of the Society was to instruct noble youths in such a way that in time they would prove their worth in pulpits, senates, secretariats, and embassies. The prudence and eloquence taught in our schools will serve the Christian state by making our former students into good preachers, senators, secretaries, nuncios, ambassadors, and others who serve the common good, he wrote. ${ }^{40}$

Cardulo continued. Jesuit humanities instruction should begin by collecting from good authors diverse materials and commonplaces that serve a Christian moral and political end. Next, the grammar and humanities classes should teach eloquence, history, and poetry. In rhetoric, students should practice every sort of verse and prose writing in preparation for careers as preachers, senators, ambassadors, secretaries, and so on. There they will use the commonplaces, materials, sentences, and discourses that they have learned. He concluded by chiding the leadership of the Society for devoting too much attention to teaching philosophy and theology and not enough to the humanities. ${ }^{41}$

In their theatrical productions, the Jesuits often celebrated historical events and individuals of the city or state in which the school was located. In such

importance of this passage and provides an English translation of most of it. For more on Ledesma's importance in the development of Jesuit educational philosophy, see Jesuit Pedagogy, 157-71, 223-32.

40 Mon. paed., nova editio, 7:128-31, quotes on 128. For an English translation, see Jesuit Pedagogy, 218-19.

41 Mon. paed., nova editio, 7:129-31; and Jesuit Pedagogy, 218-21. For references to additional statements by Jesuits about the civic benefits of a Jesuit humanities education, see Grendler, "Culture," 34n45. 
cases, the drama might not limit itself to ancient Roman examples of wise, prudent, and moral leaders of society. For example, the Polish-Lithuanian state proclaimed that it was founded on classical republican traditions that included freedoms embodied in the shared governance of monarchy, parliament, and elected judges. Jesuit theatrical productions in Lithuania portrayed rulers, nobles, legislators, and judges who practiced the virtues of prudence, courage, justice, and temperance in the service of the principles and institutions of the Polish-Lithuanian state. ${ }^{42}$

Some Jesuits held fast to the conviction that a Jesuit humanities education benefited the students and helped state and society even as secular rulers were destroying the Society. In a lengthy treatise on Jesuit education written between 1767 and 1773, Tommaso Termanini (1730-97) described its benefits in worldly, civic, and spiritual terms. ${ }^{43} \mathrm{He}$ began with the statement that it was of the greatest importance to students, parents, the state, and the Christian religion to teach the humanities to children. Those who learn letters well will be able to support themselves and achieve worldly prosperity. Teaching the humanities well was also of great importance to the state (umana repubblica), because the majority of positions that are so important to a well-ordered state depend on a humanities education. And while instructing children in letters was of the highest importance to the state and civil life (viver civile), how much more important was it to the Catholic religion and to Christian life? ${ }^{44}$ In short, the educational philosophy and purpose of the Jesuit lower school teaching humanistic studies was to instill Christian values and to teach skills and ethics

42 Jolanta Rzegocka, "Civic Education on Stage: Civic Values and Virtues in the Jesuit Schools of the Polish-Lithuanian Commonwealth," in Exploring Jesuit Distinctiveness: Interdisciplinary Perspectives on Ways of Proceeding within the Society of Jesus, ed. Robert Aleksander Maryks (Leiden: Brill, 2016), 41-61. See also Fabrizio Manuel Sirignano, "Il teatro dei gesuiti: Un esperimento di educazione del cittadino tra il 1500 e il 1600 in Europa," in Annali: Rivista di Ateneo; 2009 (Naples: Università degli Studi Suor Orsola Benincasa, 2009), 223-31.

43 Born in Modena, Termanini entered the Society in 1749, studied at the Roman College, taught philosophy at Città di Castello and Spoleto, and conducted missions in Lazio and Tuscany. After the suppression, he published a series of biographies of Jesuit missionaries to rural Italy, and wrote a life of Superior General Lorenzo Ricci $1703-75$, in office $175^{8-}$ 73), which was never printed. Mario Zanfredini, “Termanini, Tommaso," DHCJ, 4:3779.

44 Tommaso Termanini, "Della qualità che formano la perfettione propria dei maestri delle scole inferiori di questo Istituto," in ARSI, Opp. NN. 459, fols. 1-2. It was written after July 1767, because it referred to Saint José Calasanz, who was canonized on July 16, 1767 (see fol. 153) and before August 16, 1773, because of the many references to "Ours" and to individual Jesuit teachers, students, and schools in Italy, which had no meaning after 1773 . The treatise merits detailed study. 
that would enable boys and youths to earn a living and become able and virtuous leaders of state and church.

\section{The Upper School: Philosophy and Theology}

The Jesuit upper school consisted of three years of philosophy and four years of Scholastic theology. As with the lower school, instruction was free. Although linked, they served two different constituencies. The three years of philosophical study were basically the curriculum of bachelor of arts programs in northern European and Iberian peninsula collegiate universities. They were also preparation for studies in theology, law, and medicine. The four years of Scholastic theology were professional education for priesthood students and ordained clergymen.

At the ages of sixteen, seventeen, or eighteen, students who had completed the lower school and new students with the requisite Latin to read the texts began three years of philosophical study. ${ }^{45}$ The first year was devoted to logic, and the curricular texts were Aristotle's Categories, On Interpretation, Prior Analytics, Topics, and Sophistical Refutations, five of the six works of the Organon. The Ratio studiorum also encouraged the teacher to use the logic manuals of two Jesuits, the Introductio in dialecticam Aristotelis (Introduction to Aristotle's logic; first published in 1561) of Francisco de Toledo (1532-96) and the Institutionum dialecticarum libri octo (Principles of logic in eight books; first published in 1564) of Pedro da Fonseca (1528-99). ${ }^{46}$

The second-year course was natural philosophy, which was Aristotelian science. The Jesuits viewed it as a way of teaching cosmological and ontological reality by studying different forms of being. The Physics of Aristotle came first; indeed, the Jesuits often called the course physica and the students physici because of the importance of this text. Next came simple eternal substances as discussed in On the Heavens of Aristotle. Then came simple non-eternal substances, discussed with the aid of On Generation and Corruption, followed by mixed inanimate substances based on the Meteorology. ${ }^{47}$

The third-year course was metaphysics. Again, all the texts were works of Aristotle, usually selected parts, notably book 2 of On Generation and Corruption, plus the Metaphysics, especially books 1, 7, and 12, and On the Soul. ${ }^{48}$ The Ratio studiorum instructed teachers to proceed cautiously with "interpreters

45 These were average ages. Some were considerably older, a handful were younger. There were no age prerequisites in Jesuit schools.

46 Ratio studiorum, paragraphs 213-18, 220.

47 Ratio studiorum, paragraphs 219, 221-23.

48 Ratio studiorum, paragraphs 224-26. 
of Aristotle who do not serve Christianity well," mentioning Averroes (Ibn Rushd, 1126-98) and Alexander of Aphrodisias (fl. second or third century CE) by name. Jesuit philosophers of the sixteenth and seventeenth centuries vigorously debated how they should handle non-Christian authors who denied or cast philosophical doubt on fundamental Christian beliefs such as the immortality of the soul. ${ }^{49}$

The Ratio studiorum told the students attending the natural philosophy classes that they "should also attend a forty-five-minute mathematics class." And it mentioned a professorship of moral philosophy whose holder should lecture on Aristotle's Nicomachean Ethics to the metaphysics students "for thirty or forty-five minutes a day." ${ }^{\prime 50}$ In reality, mathematics was only taught in Jesuit schools and universities when there was a Jesuit mathematician available. In practice, only the largest and most important schools, typically one to three schools in a Jesuit province, taught mathematics. Moral philosophy was rarely taught even in the most important schools. On the other hand, the Ratio studiorum also stated that "if there are any who are suitable for these [mathematical] studies, they should work on them in private classes after the course."51 This happened, with the result that the Society produced some extraordinarily able Jesuit mathematicians in the seventeenth and eighteenth centuries. But it did not produce very many ordinary mathematics teachers.

The Ratio studiorum told Jesuit teachers of logic, natural philosophy, and metaphysics that they should teach two hours daily, one in the morning and one in the afternoon, and they did. By contrast, teachers in non-Jesuit universities normally lectured one hour daily. Students took notes and Jesuit scholastics were required to take detailed notes. To make sure that Jesuit teachers taught well, the Ratio studiorum ordered the prefect of studies to visit classes at least once a month, and now and then he should read student notes. The Jesuits did not like philosophy teachers to dictate material, but permitted it for the sake of weaker students, although professors in non-Jesuit universities criticized them for this. ${ }^{52}$ (By contrast, dictation was an essential part of lower-school instruction and never questioned.) After each lecture, philosophy

49 Ratio studiorum, paragraphs 209-13, quote on p. 100. See Jesuit Pedagogy, 223-32, 311-15, for the divergent views of Diego de Ledesma and Benet Perera (1535-1610). There is a large and learned bibliography on this topic.

50 Ratio studiorum, paragraphs 38 and 236, quotes on pp. 19 and 109.

$5^{1} \quad$ Ratio studiorum, paragraph 38 , quote on pp. 19-20. See also the comments of Christoph Clavius (1538-1612) about how Jesuits should teach mathematics in Jesuit Pedagogy, 281-300.

52 Ratio studiorum, paragraphs 137-38, 215; and Grendler, Jesuits and Italian Universities, $411-12$. 
students were expected to review the material for a half hour in groups of ten without the teacher present. They were also required to participate in monthly disputations, which were formal structured arguments, about the material learned. ${ }^{53}$

The apex of the Jesuit curriculum was four years of Scholastic theology based on the works of Thomas Aquinas (1224/25-74) but not limited to them. A Jesuit school of theology was expected to have at least two professors of Scholastic theology and preferably a third. Although the Ratio studiorum did not tell theology teachers how many hours a day to lecture, in practice they lectured one hour a day, which meant five or six hours per week. Using the Summa theologica of Aquinas as its reference point, the Ratio studiorum prescribed in detail the theological material to be taught. Jesuit scholastics, members of other religious orders, secular clergymen, and possibly a handful of laymen attended Jesuit Scholastic theology lectures. ${ }^{54}$ The Ratio studiorum made provision for a professor of scripture who was expected to read Hebrew and Greek. ${ }^{55}$ However, only the largest and most important Jesuit schools had a scripture professor. The Ratio studiorum also made provision for a teacher of Hebrew, but very few Jesuit schools or universities had one. ${ }^{56}$ However, sometimes the scripture professor taught biblical Hebrew.

The Ratio studiorum expected that Jesuits and others who did the full theological curriculum would study theology for four years. This was a revolutionary change in clerical education that has been little noticed. Members of the medieval mendicant orders studied theology for up to a dozen years in pursuit of doctorates of theology, which few obtained. At the other extreme, most secular clergymen, the men who would become parish priests, had little theological preparation, certainly far less than four years. And their studies were not so intense, structured, or with such able teachers as the Jesuits. Four years of theological study was ideal for the Jesuits because it enabled them to move quickly into their ministries in the world. Eventually, four years of theological study became the norm for priests in most of the Catholic world.

The Jesuit theological class most often taught and attracting the largest enrollments was cases of conscience. Cases of conscience, also called casuistry, is a branch of moral theology. ${ }^{57}$ Catholic moral theology is predicated on

\footnotetext{
53 Ratio studiorum, paragraphs 115, 137, 213, and 230-33.

54 Ratio studiorum, paragraphs $174-96$ and pp. 69-95.

55 Ratio studiorum, paragraphs 149-68.

56 Ratio studiorum, paragraphs $169-73$.

57 The following discussion of the development of Jesuit cases of conscience is based on Giancarlo Angelozzi, "L'insegnamento dei casi di coscienza nella pratica educativa della Compagnia di Gesù," in La Ratio studiorum:Modelliculturali e pratiche educative deigesuiti
} 
the supposition that human beings are free to make informed moral choices; hence, moral theology is the analysis of the principles of good and evil that influence those choices. Cases of conscience is the application of the principles of moral theology to human actions, especially sins. Cases of conscience instruction taught a confessor how to understand different kinds of sins, under what conditions he might grant or must refuse absolution to the sinner, what penances he should impose, and which sins and sinners must be referred to higher ecclesiastical authority for resolution. The most important texts for cases of conscience were manuals for confessors, whose contents included limited analysis of moral principles, followed by many pages on the Ten Commandments, church laws, definitions of sins, and the penances confessors should impose. ${ }^{58}$

Although the study of cases of conscience originated in the Middle Ages, it was not a major part of theological instruction. Then the Council of Trent $\left(1545^{-63}\right)$ affirmed the role of priests in judging and absolving sins and determining penances, and it insisted on more education for priests. Bishops began to examine priesthood candidates more rigorously, which obliged the latter to study penitential matters. But how and where would they learn? Universities did not teach cases of conscience. The medieval mendicant orders did in some of their convent studia, but few parish priests had access to them.

The Jesuits filled the lacunae. In town after town, a Jesuit lectured on cases of conscience to parish priests. As the Ratio studiorum wrote: "He [the lecturer on cases of conscience] should strive to devote all his effort [...] to the training of skilled parish priests or ministers of the sacraments." ${ }^{59}$ The cases lectures were separate from the four-year Jesuit Scholastic theology curriculum and were not necessarily delivered in the Jesuit school. Instead, a Jesuit often lectured in the cathedral, the Jesuit church, or another church; and he might lecture only three days a week..$^{60}$ The vast majority of the parish priests who attended lacked extensive theological training and the fluency in Latin that

in Italia tra Cinque e Seicento, ed. Gian Paolo Brizzi (Rome: Bulzoni Editore, 1981), 121-62; O'Malley, First Jesuits, 140-47; Edwin L. Lisson, Eduardo Moore, and James T. Bretzke, “Teología: V. Moral," DHCJ, 4:3739-45; Eduardo Moore, “Casos de conciencia," DHCJ, 1:69194; and Moore, “Teología: V.2. Casuismo," DHCJ, 4:3747-48.

58 Miriam Turrini, La coscienza e le leggi: Morale e diritto nei testi per la confessione della prima Età moderna (Bologna: Il Mulino, 1991).

59 Ratio studiorum, paragraph 197, quote on p. 95. However, the rest of the short section (paragraphs 198-206) concerns the teaching of cases of conscience to theology students and to Jesuits. There is no advice about teaching cases to parish priests.

6o This statement is based on my research in ARSI on the teaching of cases of conscience in Jesuit colleges across Italy. 
came from years of Jesuit schools. Hence, the lectures were delivered in the vernacular. Cases of conscience instruction was service teaching tailored for a defined clientele.

The Jesuits taught much more casuistry than Scholastic theology or philosophy. In 1696, for example, fifty-five percent (sixty-eight of 123) of the Jesuit schools in Italy had a lecturer of cases of conscience. By contrast, only twenty-one percent (twenty-six of 123 schools) taught Scholastic theology, often a single course. And only fifty-two percent (sixty-four of 123 schools) taught one, two, or three courses in philosophy. ${ }^{61}$ The cases lectures had higher enrollments than Scholastic theology or philosophy classes (see "Classes and Enrollments" below). Although not part of the regular Jesuit curriculum, cases of conscience lectures may have been the most direct and practical Jesuit contribution to clerical education.

\section{$9 \quad$ The Roman College}

The most important school of the Society was the Roman College (Collegio Romano), a day school. On February 22, 1551, the Society placed a sign over the door of a building in central Rome: "Schola de Grammatica, d'Humanità e Dottrina Christiana, gratis" (School of Latin, the humanities, and Christian doctrine, free).$^{62}$ The sign announced that a new school offering free instruction in the Latin humanities and catechetical instruction had opened. By the end of 1551, the Roman College had nearly three hundred students. It added philosophy and theology courses in the academic year $1553^{-54}$, which attracted more students. In 1561, the Roman College enrolled about nine hundred students,

61 ARSI, Rom. 66, fols. $283^{-}-321$; Mediol. 4, fols. $166^{\text {r }}-187^{\text {v }}$; Venet. 49, fols. 50, 106-30; Neap. 88, fols. $179^{\mathrm{V}}-234^{\mathrm{r}}$; and Sic. 91 III.

62 Translating "Grammatica" as "Latin" more accurately conveys the meaning of the word in 1551. Ricardo García Villoslada, Storia del Collegio Romano dal suo inizio (1551) alla soppressione della Compagnia di Gesù (1773) (Rome: Apud Aedes Universitatis Gregorianae, 1954), 19. This book, which is based on an eighteenth-century manuscript that I have examined, remains the best study of the Roman College before 1773. However, a larger study of more than one volume needs to be written. For the origins and first century of the Roman College, see also Farrell, Jesuit Code, 65-91; Mario Fois, "Il Collegio Romano: L'istituzione, la struttura, il primo secolo di vita," Roma moderna e contemporanea 3, no. 3 (1995): 571-99; and Francesco C. Cesareo, "The Jesuit Colleges in Rome under Everard Mercurian," in Mercurian Project, $65^{-21}$. There are many documents concerning the Roman College in all seven volumes of the Mon. paed., nova editio. A handful have been translated in Jesuit Pedagogy, 65-68, 83-91, and 157-71. 
of whom approximately 530 were lower-school students and about 370 were upper-school students. ${ }^{63}$

Pope Gregory XIII $(1502-85$, r.1572-85) provided the funding to erect a large permanent building. When it opened in 1584, it was the largest school building in Italy and may have retained that position until the twentieth century. It provided classrooms, a library, and modest living accommodations for some Jesuits. In 160o, the Roman College had an estimated two thousand students in twenty-three classes from the lowest Latin grammar class through theology. Enrollment grew to 2,300 to 2,500 students in twenty-nine classes, which must have strained the capacity of the building, at the end of the seventeenth century. ${ }^{64}$ Today, the building houses the Liceo Classico Statale Ennio Quirino Visconti, a state secondary school teaching a Latin, Greek, and Italian literature curriculum, with about 740 students.

More important than enrollment numbers were the Jesuit teachers and their scholarship. ${ }^{65}$ Many of the most brilliant Jesuits taught at the Roman College, men such as Benet Perera in philosophy and theology, Bellarmine and Suárez in theology, and Christoph Clavius and Ruđer Josip Bošković (Ruggiero Giuseppe Boscovich, 1711-87), the most famous Jesuit mathematician and polymath of the century, in mathematics. ${ }^{66}$ So did numerous Jesuits known for their humanistic scholarship, men such as Sforza Pallavicino (1607-67), author of a history of the Council of Trent, who taught several subjects and then served as prefect of studies. Student notes, course summaries, and teacher and student publications extended the instruction of the Roman College far beyond Rome.

The Roman College faithfully followed the Ratio studiorum but also eventually added new courses. At the end of the seventeenth century, it began to teach canon law. This provoked strong opposition and legal action from the University of Rome. The Roman College lost the legal battle but won the war through persistence and by giving the canon law class a different title. ${ }^{67}$ In 1742,

63 See Farrell, Jesuit Code, 67; and Scaduto, Laínez: L'azione, 281, for these enrollment numbers.

64 Grendler, Jesuits and Italian Universities, 320-21. See also 328-29, 336-37, which reproduce the rotoli, the list of courses and texts taught, but not the names of the teachers, for the academic years $1696-97$ and 1699-1700.

65 For a list of the Jesuits who taught in the Roman College through 1773, see Villoslada, Il Collegio Romano, 322-36.

66 For a brief biography of Bošković, see Ivan Strilič, "Bošković, Rudjer [Ruggero] Josip," DHCJ, 1:499-500.

67 Grendler, Jesuits and Italian Universities, 322-39, 346. 
it introduced a professorship of church history and in 1748 a professorship of liturgy without any controversy. ${ }^{68}$

The Roman College taught multiple student constituencies, beginning with an enormous number of lay boys and youths from the Roman lower, middle, and upper classes. It also taught eight future popes and many future cardinals. ${ }^{69}$ It educated lay youths and seminarians who lived in the national colleges educating priests for other parts of Europe (see "National Colleges" below). It taught youths and young men from the Roman seminary, which trained secular priests for the archdiocese of Rome. It taught cases of conscience to parish priests and other clergymen. The Roman College taught Jesuit scholastics from the province of Rome; in addition, some of the most promising scholastics from other provinces were sent to Rome to study. The Roman College was the most important Jesuit school because of the high quality of the instruction and scholarship of its teachers and for its able and influential students.

\section{$10 \quad$ Classes and Enrollments}

Examination of the schools in the province of Milan reveals large and small schools, their academic offerings, and enrollment patterns.

In October 1659, the superior of the Jesuit province of Milan visited the college at Cremona in order to resolve a personnel problem. He then decided to devote 1660 and 1661 to an inspection trip of the nineteen Jesuit colleges, all with schools, in the province of Milan. It was an arduous visitation, because the Jesuit province embraced what is now Lombardy, Piedmont, plus Ajaccio and Bastia in Corsica, at that time ruled by the Republic of Genoa. Visitation trips were common; what was unusual is that the superior noted school and class enrollments and his records have survived.

Milan had the largest school by far, and it offered all the classes recommended by the Ratio studiorum.

68 Villoslada, Collegio Romano, 252-58, 326.

69 The popes were Gregory xv (r.1621-23), Urban viıi (r.1623-44), Clement IX (r.1667-69), Clement X (r.1670-76), Innocent XII (1691-1700), Clement XI (1700-21), Innocent XIII (r.1721-24), and Clement XII (r.1730-40). See the articles on these popes by various authors in DHCJ, 3:2983, 2987, 2988, 2990, 2991, 2993, 2994; and Ludwig von Pastor, The History of the Popes from the Close of the Middle Ages, trans. F. I. [Frederick Ignatius] Antrobus et al., 40 vols. (London: Herder, 1891-53), 27:42. See also Villoslada, Il Collegio Romano, 311. In addition, Innocent XI (r.1676-89) studied in the Jesuit school at Como. DHCJ, 3:2988. 
Upper School: Theology

\begin{tabular}{lrrr} 
Scholastic Theology (two classes) & 130 students & \\
Cases of Conscience & 200 & \\
Scripture & 50 & & \\
Hebrew & 35 & Subtotal & 415 \\
\hline Upper School: Philosophy & & & \\
Mathematics & 50 & & \\
Metaphysics & 70 & & \\
Natural Philosophy (Physica) & 85 & Subtotal & 418 \\
Logic & 213 & & \\
\hline
\end{tabular}

Lower School: Humanistic Studies

\begin{tabular}{llllll}
\hline Rhetoric (two classes) & 124 & & & \\
Humanities (two classes) & 210 & & & \\
Upper Grammar (two classes) & 300 & & & \\
Middle Grammar (two classes) & 222 & Subtotal & 980 & Total class & 1,813 \\
Lower Grammar & 124 & & & enrollment &
\end{tabular}

SOURCES: ARSI, MEDIOL. 73, FOLS. 168R-169V (JANUARY 14, 1661). SIMONA NEGRUZZO, COLLEGII A FORMA DI SEMINARIO: IL SISTEMA DI FORMAZIONE TEOLOGICA NELLO STATO DI MILANO IN ETÀ SPAGNOLA (BRESCIA: EDITRICE LA SCUOLA, 2001), 129.

The total number of students may have been less than the 1,813 count from individual classes. It will be remembered that the Ratio studiorum told natural philosophy students to attend a short daily lecture in mathematics as well as their two daily natural philosophy lectures, although at most only fifty of the eighty-five natural philosophy students in the Milan school did so. It is also possible that some Scholastic theology students attended scripture or Hebrew lectures in addition to two daily lectures in Scholastic theology. On the other hand, because the subject matter of the scripture, Hebrew, and mathematics classes was difficult and required a strong commitment, it is possible that there were some students who attended only one of these classes and no others. Finally, the total number of teachers was eighteen. 
The large city of Milan provided an abundance of lay boys for the lower-school classes. In addition, as noted, many lay youths intending to study law or medicine at university attended the logic and natural philosophy classes. The college of physicians of Milan, the professional organization that licensed physicians, encouraged this by allowing candidates for the doctorate in medicine to count three years of philosophical study at the Milan Jesuit school toward the seven years of philosophy and medicine courses required for the decree. ${ }^{70}$ Hence, some students studied philosophy in the Jesuit school and then went to the University of Pavia, the university of Lombardy, to obtain doctorates of medicine. Clergymen, either priests or men in minor orders aspiring toward ordination, filled the theology classes. About twenty-five of them were Jesuit scholastics. Other theology students came from the seminary of the archdiocese of Milan, other diocesan clergy, and members of other religious orders. Parish priests and other local confessors provided the bulk of students for the cases of conscience class.

The other day schools in the province of Milan were much smaller. The next largest was Turin. It offered nine classes (the same as Milan except for scripture, Hebrew, mathematics, and middle grammar, and only one class in Scholastic theology) with a school enrollment of 892 students. $^{71}$ The school in the small city of Novara represented another curricular and enrollment model: it offered a complete lower school but only a single philosophy class, plus cases of conscience for pastors.

TABLE 2 Novara school enrollment in 1660

\begin{tabular}{llll}
\hline Cases of Conscience & 80 & & \\
Philosophy & 15 & & \\
Rhetoric & 35 & & \\
Humanities & 80 & Total enrollment & 330 \\
Upper Grammar & 70 & & \\
Lower Grammar & 50 & & \\
\hline
\end{tabular}

SOURCE: ARSI, MEDIOL. 73, FOL. $158^{\mathrm{R}-\mathrm{V}}$ (JULY 1660); AND NEGRUZZO, COLLEGIJ, 367.

$70 \quad$ Flavio Rurale, I gesuiti a Milano: Religione e politica nel secondo Cinquecento (Rome: Bulzoni, 1992), 145-46.

71 ARSI, Mediol. 73, fol. $15^{2^{\mathrm{r}-\mathrm{v}}}$ (May 166o). 
The fact that the curriculum listed only one course in philosophy, instead of courses in metaphysics, natural philosophy, and logic, meant that the teacher improvised. He may have taught a course that combined elements of metaphysics, natural philosophy, and logic. Or he may have taught logic one year, then natural philosophy the next year, but probably not metaphysics in a third year, because it was not likely that there was great demand for it.

The rest of the schools in the province were smaller. Some offered four courses: cases of conscience plus rhetoric, humanities, and grammar, for a total of 125 to two hundred students. Pavia is an example: its cases of conscience class enrolled fifteen students, rhetoric thirty, humanities forty, and grammar fifty, for a total enrollment of 135 students. ${ }^{72}$ And about half of the schools in the province of Milan offered only two or three classes, that is, humanities and one or two grammar classes, for a total enrollment of fewer than one hundred students. For example, the school at Chieri taught ninety-five students (thirty-five in the humanities class and sixty in the grammar class), and the school at Vercelli taught seventy students in three classes (humanities thirty-five, upper grammar twenty-five, and lower grammar twenty students). ${ }^{73}$

Overall, in 1660 and 1661 the nineteen schools of the province of Milan enrolled 5,388 students, an average of 284 students per school, but only 199 students per school if Milan is omitted. ${ }^{74}$ The students were mostly lay boys and youths. Of the total, 3,848 students attended the lower schools that taught humanistic studies. These were practically all lay boys and youths with a smattering of them in minor orders. In addition, the vast majority of students attending the philosophy and mathematic classes were probably also lay boys, plus a small number of Jesuit scholastics. Only the 730 students who attended the classes of Scholastic theology, cases of conscience, scripture, and Hebrew were certainly clergymen or future clergymen. Hence, about eighty-six percent $(5,388$ minus 730 equals 4,658 divided by 5,388$)$ were lay students.

The province of Milan pattern was typical. All across Europe, Jesuit day schools offered all or part of the courses of the Jesuit curriculum and had enrollments ranging from one to two thousand down to one hundred and fewer. The size of Jesuit schools and individual class enrollments in France were roughly similar to the province of Milan, albeit with more schools with enrollments of one thousand and more. ${ }^{75}$ In 1771, the province of Austria had about three times as many Jesuits, schools, and pupils as the province of Milan but

\footnotetext{
72 ARSI, Mediol. 73, fol. 170 ${ }^{\mathrm{r}}$ (December 1661); and Negruzzo, Collegij, 232.

73 ARsi, Mediol. 73 , fols. $150^{\mathrm{r}-\mathrm{v}}$ (Chieri in May 1660), $160^{\mathrm{r}-\mathrm{v}}$ (Vercelli in July 166o).

74 ARsi, Mediol. 73 , fols. $133^{\mathrm{r}}-90^{\mathrm{v}}$.

75 François de Dainville, L'éducation des jésuites (XVI ${ }^{e}-X V I I I^{e}$ siècles), textes réunis et présentés par Marie-Madeleine Compère (Paris: Les Éditions de Minuit, 1978), 81-149.
} 
a similar spread between large and small schools. Vienna and Graz had over a thousand students, Nagyszombat (Trnava in Slovakia) had between eight hundred and nine hundred, and all the rest had enrollments ranging from six hundred to fewer than a hundred..$^{76}$ There were ten schools in the province of Lithuania in 1618: Vilnius had 1,210 students, while five schools had fewer than one hundred students. ${ }^{77}$ Although Jesuit schools with very large enrollments for those times have rightly attracted the most scholarly attention, the abundance of smaller schools presents a more accurate picture of Jesuit education.

Class-by-class enrollments were pyramidal in both the lower school for humanistic studies and the philosophy upper school. That is, the lowest grammar class had the most students, the middle grammar class the second most, and so on through the rhetoric class, which had the smallest enrollment in the lower school. The same was true for logic, natural philosophy, and metaphysics; indeed, in many schools the one or two philosophy classes had fewer students than the rhetoric class.

Diminishing enrollments in classes of ascending difficulty have been a feature of practically every school system in history including modern universal public education systems that mandate attendance to a certain age. The dropout rate was much higher in past centuries when education was optional for several reasons. Learning a complicated language like Latin is not easy; students left when they fell behind, in part because Jesuit school culture did not provide much encouragement for students of lesser abilities (see the next section). Or students left when families needed their labor. Or parents decided that their sons were ready to fill a middle-class position, such as an administrative post in city government, that needed good but not superlative Latin. This may have been a major reason for the enrollment drop between humanities and rhetoric classes, and that many small Jesuit schools did not teach rhetoric. Few students needed to be polished Latin orators in order to earn a living. In similar fashion, after studying logic and natural philosophy, students were ready for university studies in law or medicine, for which metaphysics was unnecessary.

\section{Pedagogical Practices and Classroom Culture}

The Ratio studiorum told Jesuit teachers what courses to teach, the texts to be taught, and some academic exercises to adopt. How did teachers put into practice the directives of the Ratio studiorum? A former student wrote about his years in a Jesuit school, and his account provides some answers.

\footnotetext{
76 László Szilas, "Austria. Antigua," DHCJ, 1:286, 288-89. Unlike the case in France and possibly Italy, Jesuit school enrollments were not declining in the eighteenth century in the multilingual province of Austria.

Paulius Rabikauskas, "Lituania," $D H C J$, 3:2387.
} 
Pietro Antonio Adami (1661-1722), a native of Bologna, was a student in the lower school of the Jesuit day school in Bologna. He entered the lower grammar class on November 12, 1675, at the age of fourteen, older than the norm. He spent one year in the lower grammar class, the next year in the upper grammar class, a third year in the humanities class, and two years in the rhetoric class. He left the Jesuit school on August 20, 1680, when he was nineteen. He then wrote a detailed description of his Jesuit schooling. Since the prefect of studies read and approved Adami's account, it can be trusted to be accurate. After leaving the Jesuit school, Adami eventually became an Oratorian priest (Congregation of the Oratory of Saint Philip Neri) and acquired a doctorate in theology. ${ }^{78}$

Adami began by the describing the classrooms, which were large. ${ }^{79}$ The teacher occupied a chair behind a table raised above floor level in a commanding position. Student emperor and princes (see below) occupied two or three other chairs, sometimes with small tables, placed between the teacher and the rest of the students, who sat in assigned places on rows of benches. Paintings of Jesuit saints, typically Ignatius of Loyola and Francis Xavier, hung on the walls. There were also portraits of Luigi (Aloysius) Gonzaga (1568-91, beatified in 1605 and canonized in 1726) and Stanisław Kostka (1550-68, beatified in 1602 and canonized in 1726), two Jesuits honored as patrons of youth. Additional images and frescoed ceilings celebrated ancient poets, orators, and events, such as Rome's victory over Carthage. ${ }^{80}$

Bolognese Jesuit teachers organized their class into decuries. In the ancient Roman army, a decury was a group of ten soldiers led by one of them, called a decurion. Medieval schoolmasters adapted decuries to the classroom, and Renaissance pedagogues followed suit. In 1558, Jesuit teachers in Sicily recommended that when a class was large, the teacher should create decurions who, under his direction, would oversee the other students part of the time. ${ }^{81} \mathrm{~A}$ Jesuit decury was a group of ten students led by a decurion, the best student, who assisted

78 Adami's text is edited in Fabrini, Documento, who also provides notes and a biography of Adami at p. 5. Gian Paolo Brizzi, "La scolarité de Pietro Antonio Adami chez les jésuites de Bologna à la fin du xvii e siècle," Histoire de l'éducation 124 (2009): 51-71, provides an excellent analysis. There may be additional accounts by former students that have not come to my attention.

79 Exactly how large is impossible to determine, because after the suppression, the Bologna Jesuit buildings were sold and renovated beyond recognition. For a classroom plan of the Roman College around 1700 that includes the positioning of furniture, see Jesuit Pedagogy, 168 .

8o Fabrini, Documento, 18, 30-31, 50, 52-53, 61. Although Adami described four classrooms, only a brief composite picture is offered here.

$81 \quad$ Mon. paed., nova editio, 2:235. 
the teacher by supervising the studies of the other nine. The use of decuries and decurions was standard practice in Jesuit lower schools across Europe.

The daily instruction consisted of a tightly integrated program consisting of the teacher's exposition of the material to be learned that day, memorization, recitation, composition exercises, correcting exercises, competitions, and review, in accordance with the prescriptions of the Ratio studiorum..$^{82}$ The school day was divided into segments separated by a bell. At the beginning of the school day, decurions collected student homework and passed it on to the teacher for correction. They also kept a record of those students who did not do the written work. Then, in the first hour of a grammar class, a decurion heard the recitations of memorized material, such as rules of grammar or lines from Cicero, from the other nine members of his decury. Decurions had the honor of reciting before the chief decurion of the class or the teacher. The teacher might call the attention of the whole class to a frequent error found in the homework that he had begun to correct.

In the second morning period, lasting ninety minutes, the class briefly reviewed the previous lesson. Then the teacher introduced a new passage from a text, typically from Cicero, intended to illustrate a grammatical construction. He explained it thoroughly in the vernacular. Although the Ratio studiorum strongly emphasized that teachers and students should use Latin as much as possible, it also told the teacher to explain the lessons in the vernacular as needed. The last half hour was devoted to review, or to a presentation from the grammar manual, or to a competition. The first afternoon hour began with student recitation of Latin grammatical material. In the second afternoon period lasting ninety minutes the students went over more syntax and finished with a competition or dictation. Students were assigned homework practically every night. At the end of the school day, the teacher took home a pile of student exercises to correct, because he had time to correct only a few during the day. Saturdays were largely devoted to reviewing the week's work; indeed, Jesuit classes at all levels devoted much of Saturday to review in one way or another.

The Bologna lower school classes read and studied the Latin classical texts mandated by the Ratio studiorum plus other works. In addition, teachers dictated rules and principles, for example, on how to compose a letter, that students were expected to put together into brief manuals to be memorized. All classes used dictionaries, which were not mentioned by the Ratio studiorum. The teachers of the humanities and rhetoric classes also brought to class baroque Latin books written by seventeenth-century authors to be read and discussed. ${ }^{83}$

82 What follows summarizes Fabrini, Documento.

83 Fabrini, Documento, 46, 48, 52-57, 62-63. 
On the other hand, the Bologna lower school did not teach any Greek, a major departure from the Ratio studiorum. Some French Jesuit schools also deleted Greek, which sparked a restoration movement. Beginning in the 169os, Joseph de Jouvancy (1643-1719), a French Jesuit, and his followers sought to restore Greek and the more classical Latin approach of the Ratio studiorum to Jesuit schools, with some success. ${ }^{84}$

The deviations from the Ratio studiorum raise questions that have been little studied: How much did Jesuit day schools depart from the Ratio studiorum? To what extent did they add new material and drop some of the prescriptions of the Ratio studiorum? For example, it is known that Jesuit day schools in Transylvania taught Hungarian history in the eighteenth century. ${ }^{85}$ Was this common? Even less is known about the extent to which Jesuit day schools across Europe may have omitted instruction mandated by the Ratio studiorum.

The Ratio studiorum strongly endorsed competition and rivalry (aemulatio), and the teachers and students at the Bologna school put the culture of competition into practice in multiple ways. ${ }^{86}$ Practically every student exercise was graded with positive and negative points; students who misbehaved were also assigned negative points. Student "censors" kept track of the points on large sheets of paper, and they were added at the end of the week or month. The student with the highest number of points was named emperor and the next highest became princes. Students moved forward or back in the chairs and benches. Groups of students given the names Rome and Carthage also competed. ${ }^{87}$

There were many rewards for the best students at the Bologna school. For example, a wooden escutcheon with the name of the student, his patria, motto, and coat of arms, if he had one, might be created for an excellent student. It was then hung on the wall of the classroom. This imitated the practice of the University of Bologna where student escutcheons were hung in the courtyard of the building that was the home of the university and remain there today. ${ }^{88}$ But students who performed poorly or misbehaved suffered humiliation and punishment, including slaps from a leather strap. The worst compositions were sometimes posted to be ridiculed. The student with the lowest number of positive points was declared the asino of the class: a picture of an ass was

\footnotetext{
84 Dainville, L'éducation des jésuites, 209-66; and Georges Bottereau, "Jouvancy (Juvencius), Joseph de," DHCJ, 3:2157-58.

85 Paul Shore, Jesuits and the Politics of Religious Pluralism in Eighteenth-Century Transylvania: Culture, Politics and Religion, 1693-1773 (Aldershot: Ashgate, 2007), 92-93.

86 Ratio studiorum, paragraphs 347, 349, 355, 386, 401, 414, 424, 433, and elsewhere.

87 Fabrini, Documento, 35, 37-39, 48.

88 Fabrini, Documento, 34, 40, 50.
} 
attached to his neck and a miter shaped like an ass placed on his head. ${ }^{89}$ Jesuit schools focused on stimulating the ablest students to high achievement. Those of average abilities received a thorough education and limited recognition. The least able were humiliated. On the other hand, the Bologna school did permit failing students to repeat classes, and it allowed some weak students to advance because of their age or family pleading. Such a student was called a "benchwarmer" (scaldabanco). ${ }^{90}$

Tommaso Termanini strongly urged his fellow Jesuit teachers to adopt a different strategy: they should give special attention to less able, recalcitrant, and financially poor students. He wrote that it was natural for teachers to favor students with intellectual gifts, had illustrious parents, or were useful to the teacher, but difficult to teach students who possessed less intellectual capacity and were clumsy and stubborn. But Jesuit teachers should reach out to them. Animadverting on the passages in which Jesus urged children to come to him for his blessing (Matthew 19:13-15, Mark 10:13-16; Luke 18:15-17), Termanini wrote that Jesus was calling all children including those who needed special help. And if they lacked books, paper, pens, and ink, Jesuit teachers should persuade donors to provide them or give them from their own supplies. The schoolmaster truly imitated his divine teacher when he showed partiality toward the neediest students. ${ }^{91}$

Students in the lower school at Bologna attended daily Mass at the end of the morning. In addition, they were expected to confess monthly, receive the Eucharist regularly, and hear sermons on holy days..$^{92}$ For catechetical instruction, the lower grammar class memorized an abridgment of a catechism prepared by a teacher, just as the Ratio studiorum directed, plus a catechism of Bellarmine, probably the Dottrina cristiana breve. ${ }^{93}$

Jesuit lower schools had a highly developed curriculum and pedagogical techniques honed through years of practice. Yet it took a dedicated teacher to put it all together. A Jesuit teacher had to be knowledgeable and well organized, he had to command respect, and he needed good judgment, not least in his choice of decurions. He had to lead and manage a large classroom.

Adami believed that his teachers accomplished all this. While noting their personalities and idiosyncrasies — one was reserved, another fiery, a third had the majestic countenance of an English lord-he praised their knowledge,

\footnotetext{
89 Fabrini, Documento, 34-39.

$90 \quad$ Fabrini, Documento, 42.

91 For more plus the archival references, see Grendler, "Culture," 39-41.

92 Fabrini, Documento, 28.

93 Fabrini, Documento, 48.
} 
modesty, fairness, seriousness of purpose, and friendship toward students. ${ }^{94}$ This was a common evaluation; even opponents of the Society's schools often acknowledged that the Jesuits were effective teachers. Despite the large enrollments, Jesuit teachers made Jesuit schools work. The reasons are to be found in their long and intense education and dedication to teaching minds and forming character.

Thus, Jesuits taught through a combination of strong and rigid organization, extensive student assistance, relentless competition, and an enormous quantity of oral and written exercises. As everywhere else in Europe, students at the Bologna school also participated in student Marian congregations in which they engaged in religious activities and devotions. The congregations had a scholarly component called "academies" consisting of a small number of able students who engaged in more academic exercises. And Bolognese students participated in theatrical productions and public disputations before fellow students, parents, and the public. ${ }^{95}$

12

\section{The Social Composition of the Students}

Jesuit day schools enrolled boys from all classes, the vast majority of them from the middle and lower classes. The often-repeated statement that the Jesuits mostly taught students from the upper classes is untrue. It could not possibly be true, because a huge percentage of the population of potential students came from the middle and lower classes, while the sons of the elite were very few in number. But surviving documentation on the origins of students is very sparse. Although Jesuit schools compiled matriculation lists, only a microscopically small fraction of such lists have been found. And if surviving lists do not include the names and occupations or titles of fathers of students, they are not useful for social analysis. ${ }^{96}$ Fortunately, a handful of lists with this information have been located.

A series of enrollment lists ranging from one hundred to 650 names each from the Jesuit school in Châlons-sur-Marne (renamed Châlons-en-Champagne in

94 Fabrini, Documento, 47, 48, 51, 54-55, 60.

95 Unfortunately, there is not space to discuss congregations, academies, and theatrical exercises further, and the bibliography, especially on Jesuit theater, is enormous. Start with William H. McCabe, An Introduction to the Jesuit Theater: A Posthumous Work, ed. Louis J. Oldani (St. Louis: Institute of Jesuit Sources, 1983).

96 One must have information about the father's status and/or occupation. A noble surname of student or father did not guarantee noble rank, because not every father or student bearing a prominent local noble surname was a noble. Over time, non-noble relatives, illegitimate members of the family, and employees and servants of noble households might appropriate the noble name, but not the rank and privileges of nobility. 
1998) in northeastern France for various years from 1618 through 1736 provides detailed information about the social classes of students. ${ }^{97}$ About five percent of the students were sons of noble fathers, and another six percent came from the bourgeoisie, that is, commoners of standing and wealth. About thirty-five percent of the students were the sons of officeholders, that is, state, provincial, and local government officials. The civic offices held by fathers ranged from the extremely influential to low-level employees. At the pinnacle were presidents, councilors, and lawyers of parlements and courts. In the middle were officials who oversaw a multitude of civil services and properties ranging from selling salt, dispensing grain from monarchical granaries, to guarding the king's forests. The bottom rank of officeholders consisted of beadles, monitors, and ushers. The office-holding class was a pyramid with a broad base of minor officeholders and a tiny apex of presidents and councilors.

About thirty percent of the students were sons of local merchants, shopkeepers, and tradesmen, a group that included apothecaries and surgeons. About six percent of the students were the sons of peasants and farmworkers. These boys boarded in town with relatives, friends of the family, or in commercial boarding houses, in order to attend the Jesuit day school. Some parents from nearby smaller towns also sent their sons to board and study in towns with Jesuit schools. Finally, the sons of artisans and craft-workers comprised the last twenty percent of the students. Overall, about fifty-six percent of the students at the Jesuit school of Châlons-sur-Marne came from the three lowest ranks of society. And if at least two-thirds of the office-holding fathers came from the middle and lower ranks of officeholders, then about seventy-seven percent of the students came from the middle and lower classes. ${ }^{98}$ Less comprehensive information from Jesuit schools in Auch, Billom, and Bordeaux in France, and Munich in Germany, confirms this general pattern. ${ }^{99}$ While the motivations of parents and boys for wishing to attend obviously varied, it is very likely that many did in the hope of rising in society.

The Jesuits made a move in Italy in the seventeenth century that probably increased the enrollment of students from the lower and middle classes in their day schools: they brought back ABC classes. When they began teaching in the middle of the sixteenth century, the Jesuits taught reading, writing, and

97 For this and the following paragraph, see, Dainville, L'éducation des jésuites, 107-10. I have summarized and extrapolated a little from Dainville's data.

98 "Donc 80\% au moins des écoliers châlonnais venaient des rangs moyens ou inférieurs du tiers état." Dainville, L'éducation des jésuites, 107.

99 Dainville, Léducation des jésuites, 122, 146; Andreas Kraus, Das Gymnasium der Jesuiten zu München (1559-1773): Staatspolitische, Sozialgeschichtliche, Behördengeschichtliche und Kulturgeschichtliche Bedeutung (Munich: Verlag C. H. Beck, 2001), 17-21. 
the catechism to unlettered boys in at least a few schools, and these classes were popular with parents. However, in the 155 os Ignatius began to eliminate them in order to concentrate the Society's limited human resources on teaching the Latin curriculum. In the Constitutions, he wrote that teaching reading and writing was a work of charity, but the Society would not ordinarily do this because it lacked enough members. But when parents protested, Ignatius and Laínez permitted some Jesuit $\mathrm{ABC}$ schools to continue. And both Ignatius and Laínez authorized a small number of ABC classes in schools in German lands, because they believed that boys living in heavily Protestant lands needed to be educated in a totally Catholic environment from the earliest age. Nevertheless, over time the German $\mathrm{ABC}$ classes were phased out as well. ${ }^{100}$ Eliminating the ABC-plus-Latin-syntax class undoubtedly barred many boys from the lowest rungs of society from attending Jesuit schools because, with a few exceptions, Europe lacked free schools. Even though neighborhood teachers did not charge very much to teach reading, writing, and a little Latin syntax, for one, two, or three years, the fees were still beyond the means of many parents.

The $\mathrm{ABC}$ classes returned in the seventeenth century in Italy. At least twenty-five Italian cities and towns had Jesuit-directed beginner classes around 1660, including practically every Sicilian town with a Jesuit school. ${ }^{101}$ These were classes that the Jesuits oversaw but did not teach. Instead, the local Jesuit college hired and paid a secular priest or a layman to teach reading, writing, and a little Latin grammar in a beginner class located elsewhere than the Jesuit school. The teachers followed Jesuit pedagogical directions and the classes were free. After a year or more in an $\mathrm{ABC}$ class, a student who wished to go to the Jesuit school was examined; if he passed, he entered the lowest grammar class where a Jesuit taught him.

The reappearance of the Jesuit-sponsored beginning classes in Italy in the seventeenth century has almost escaped notice, and the reasons why the Jesuits

100 The Constitutions of the Society of Jesus and Their Complementary Norms: A Complete English Translation of the Official Latin Texts, ed. John W. Padberg (St. Louis: Institute of Jesuit Sources, 1996), paragraph 451, p. 180; Mon. paed., nova editio, 3:89, 289n4, 499-505 (1571 decision of the Viennese Jesuits to eliminate the ABC class); Farrell, Jesuit Code, 196, 208, 302; Scaduto, Laínez, il governo, 352-54, 402; and Scaduto, Laínez, l'azione, 334, 336, 340,377 .

101 ARSI, FG 1527, a bundle of documents for Perugia; FG 1598, a bundle of documents for Sezze; and FG 1605, a bundle of documents for Sicily. See also Brizzi, "La scolarité," 54 including note 11, who found six ABC classes in the Jesuit province of Venice. It is difficult to locate $\mathrm{ABC}$ classes because the triennial catalogs (the reports from individual colleges listing, among other things, the number of classes in Jesuit schools) in ARSI do not mention the beginner classes because they were not taught by Jesuits. But they sometimes appear in visitation reports and other documents. 
brought them back need to be investigated. The most likely reason is that parents and city councils wanted them, and the Jesuits now had the resources to oblige. There were advantages to the Jesuits. Because the boys learned from Jesuit-appointed teachers, they were introduced to Jesuit pedagogy from the beginning and were well prepared for the Jesuit school. And because the beginner classes were free, boys from poor and middle-class families had more educational opportunity. There is scattered evidence that Jesuit-sponsored ABC-plus-Latin-syntax classes reappeared elsewhere in Europe after the $155{ }^{0 .} .^{102}$ But much remains to be investigated.

\section{Jesuit Boarding Schools}

The Society also created and managed boarding schools in which students lived and studied under the supervision of Jesuits. Although boarders walked daily to classes in the town's Jesuit day school, sometimes only steps away, they received supplementary tutoring in the residence and sometimes instruction in disciplines and skills not taught in the day school. Most important, the boarders lived under the direct religious supervision of Jesuits. In spirit, Jesuit boarding schools resembled fifteenth-century Italian humanistic schools in which students lived and studied in the master's home in the expectation that he would shape their minds through teaching the classics and their character by his good example. Jesuit boarding schools also anticipated English public schools and American college preparatory boarding schools in which students lived and studied for the entire academic year away from home in a semi-rural setting, except that Jesuit boarding schools were located in cities and towns.

The Jesuits in Germany and Austria founded boarding schools in addition to day schools almost from the moment of their arrival. For example, the Jesuits arrived in Vienna in 1551, founded a day school, and added a boarding school in 1554. The impetus came from parents and donors, notably the son of the chancellor of the Vienna Habsburgs who provided a large house. The students paid fees, which meant that the students were the sons of nobles and other wealthy fathers. It expanded to 120 paying boarders, described as seven canons and the rest sons of nobles and citizens, in $1574 .{ }^{103}$

The Viennese Jesuits were not finished. Shortly after 1554 they founded a boarding school for poor students who did not pay fees. They lived in a separate

102 For example, at various times between 1562 and 1586 the Jesuits in Anvers, Brussels, Dinant, and Tournai in the Spanish Netherlands sponsored ABC classes taught by non-Jesuits. Poncelet, Histoire, 2:10-11. Whether they continued in the seventeenth and eighteenth centuries is unknown.

103 Duhr, Geschichte der Jesuiten, 1:295-96; Mon. paed., nova editio, 4:518. 
building called the collegium novum (new college), which had twenty-two boarders in 1559 and twenty-six in 1563 . The rules for the new college indicated that it was expected that some of the boarders would become clergymen, including boys who joined the Society. The Viennese Jesuits added a third boarding school in Vienna in 1574, a papal seminary that began with twenty-five students, when Pope Gregory XIII agreed to support financially German-speaking priesthood students abroad. ${ }^{104}$

The Jesuits of Germany and Austria were more strongly committed to boarding schools than Jesuits in other parts of Europe, because they feared the deep penetration of heretical ideas among the educated and doctrinal confusion among the faithful. They believed that a complete Jesuit academic and living environment would be particularly effective in keeping Germany and Austria Catholic. Hence, Jesuit colleges in Dillingen, Ingolstadt, Cologne, Mainz, Fulda, Braniewo, Munich, Innsbruck, Graz, and Augsburg followed the lead of the Viennese Jesuits in founding boarding schools for paying students, poor students, and papal seminarians. However, they did not necessarily create three different institutions, but sometimes founded a single boarding school in which three different categories of students lived. ${ }^{105}$

The boarding schools came with substantial personnel and financial costs. Each boarding school required the services of several Jesuits including a rector, a confessor, and ripetitori ("repeaters," that is, Jesuit scholastics who tutored the boarding students), plus salaried laymen who served as cooks, purchasers, cleaning staff, and so on. In addition, the Jesuits had to find donors to provide the funds to support the poor students. Hence, by the 1580 s some German Jesuits questioned whether the results justified the substantial commitment of resources. In 1585, a prominent German Jesuit argued that boarding school students made no more progress in piety and learning than non-boarders. Worse, they sometimes misbehaved, which reflected badly on the Jesuits. ${ }^{106}$ This may have been a minority opinion. In any case, pressure from parents and donors made it difficult for the Jesuits to close boarding schools.

In the seventeenth century, the Jesuit boarding schools in Habsburg lands emerged stronger than ever. This was an unexpected consequence of the combination of the Thirty Years' War and the strong Counter-Reformation reputation of the Jesuits. In the previous century, the Protestant Reformation had had

104 Duhr, Geschichte der Jesuiten, 1:296, 300-2; Mon. paed., nova editio, 3:97, 302.

105 Duhr, Geschichte der Jesuiten, 1:297-309.

106 Duhr, Geschichte der Jesuiten, 1:319-24. This was Paul Hoffaeus (c.1530-1608), assistant for the German-speaking lands and previously rector of the college at Vienna and superior of the province of Upper Germany. See John Patrick Donnelly, "Hoffaeus, Paul," DHCJ, 2:1932-33. 
a devastating effect on the medieval monastic orders, the Augustinian Canons, Friars, and Hermits, Benedictines, Capuchins, Carmelites, Carthusians, Dominicans, Franciscans, Premonstratensians, Servites, and others. Their members belonged to individual monasteries that were supported by income-producing properties and benefices. Many monastic communities emptied out when the majority of the members became Protestants or when Protestant troops seized the monastery. When Catholic forces regained control of a territory in the Thirty Years' War, the issue of the restoration of the monastery and its income rose, particularly if there were few remaining monks, friars, or canons regular of the monastery or the religious order in the area to occupy it. Emperor Ferdinand II Habsburg (1578-1637, r.1619-37) believed that the Jesuits and their schools strengthened Catholicism and combated heresy more effectively than other religious orders. Hence, urged by his Jesuit confessor and with the approval of the papacy, he transferred to the Society many monasteries and their incomes from other religious orders to the Jesuits. ${ }^{107}$ The Jesuits, in turn, expanded their boarding schools and founded new ones. They enrolled the same mix of sons of the powerful, poor students, and future priests as before. And they enrolled some members of medieval religious orders whose monasteries were gone. ${ }^{108}$

\section{Schools in Eastern Europe}

In the later sixteenth and early seventeenth centuries, the Society expanded considerably in eastern Europe, the lands that are now Hungary, the Czech Republic, Slovakia, Poland, Lithuania, Latvia, Estonia, Slovenia, Croatia, and Romania (then called Transylvania). The Jesuits proceeded as they did in Germany and Austria. With the assistance of rulers, especially the Habsburgs, and city councils, they established day schools; boarding schools with mixed enrollments of aristocratic students, poor students, and future clergymen; and noble boarding schools. They supervised and taught in diocesan and pontifical seminaries. ${ }^{109}$

107 Robert Bireley, Religion and Politics in the Age of the Counterreformation: Emperor Ferdinand II, William Lamormaini, S.J., and the Formation of Imperial Policy (Chapel Hill, NC: University of North Carolina Press, 1981); and Bireley, The Jesuits and the Thirty Years War: Kings, Courts, and Confessors (Cambridge: Cambridge University Press, 2003).

108 Duhr, Geschichte der Jesuiten, vol. 2, part 1:607-56.

109 Because I do not read eastern European languages, this and the following two paragraphs are based on the following, each of which has considerable bibliography. László Szilas, "Austria. 1. Antigua," $D H C J$, 1:277-92; Robert S. Gerlich, "Chequia," $D H C J$, 1:76o-64; Miko Korade and Bogumil Remec, "Croacia y Slovenia," $D H C J$, 2:1006-7; Stanislaus Kuĉinskis, "Letonia y Estonia," $D H C J$, 3:2338-40; Paulius Rabikauskas, "Lituania," in $D H C J$, 3:238693; Ludwik Piechnik and Ludwik Grzebień, "Polonia," DHCJ, 4:3173-80; Paul Shore, The Eagle and the Cross: Jesuits in Late Baroque Prague (St. Louis: Institute of Jesuit Sources, 
Jesuit schools in religious and linguistic border regions had to negotiate difficult terrains. Eastern Europe had much more religious diversity than the rest of Europe. Some towns in eastern Europe had Catholics, Calvinists, and Lutherans; there were many Hussites in Prague and Bohemia, plus Anabaptists and anti-Trinitarians in Poland. The Jesuits necessarily took a more active and direct role in religious controversies with non-Catholics than they did in western Europe. And securing religious conversions was a major goal. The question of whether Jesuit schools should accept Protestant students arose at an early point. In 1566, Nadal told the Viennese Jesuits to admit them, so long as they accepted the rules of the school, attended Mass, and heard the catechism and the Catholic creed. ${ }^{110}$ Hence, Jesuit schools enrolled Protestant students and hoped that they would become Catholics.

Some Protestant students in Jesuit schools in eastern Europe did become Catholics, and Jesuit annual letters celebrated such conversions. But it is difficult to know how frequently Protestant students became Catholics. A study of school conversions in the first half of the seventeenth century in western Hungary, a territory in which some towns were divided between Catholics and Lutherans, found that about ten percent of Protestant students in Jesuit schools became Catholics. ${ }^{111}$ Whether that figure was typical must await further research. And whether Jesuits viewed a conversion rate of ten percent as high or low depended on their expectations.

The peoples of eastern Europe spoke and wrote numerous languages. Initially, the majority of Jesuits who taught in eastern European schools were German-speakers who were usually educated in major Jesuit centers such as Rome and Vienna. With schools came vocations and Jesuits whose native languages were Czech, Hungarian, Lithuanian, Polish, and other languages. Soon these new Jesuits began to publish works in their native languages as well as in Latin. For example, Jesuits published dictionaries, grammars, catechisms, sermons, and translations of the New Testament into Baltic languages. Eastern European Jesuits may have made a proportionately greater contribution to the

2002); Shore, Jesuits in Transylvania; and Shore, Narratives of Adversity: Jesuits on the Eastern Peripheries of the Habsburg Realms (1640-1773) (Budapest: Central European University Press, 2012). The excellent study of Jakub Niedźwiedź, "Jesuit Education in the Polish-Lithuanian Commonwealth (1565-1773)," Journal of Jesuit Studies 5, no. 3 (2018): 441-55, appeared too late to incorporate into the text.

110 Mon. paed., nova editio, 3:117-18.

111 Zsófia Kádár, "The Difficulties of Conversion (of) Non-Catholic Students in Jesuit Colleges in Western Hungary in the First Half of the Seventeenth Century," Hungarian Historical Review 3, no. 4 (2014); http://hunghist.org/archive/83-articles/277-2014-4-kadar. 
development of and the scholarship about the vernacular literatures of their homelands than western European Jesuits did for French, Italian, and Spanish.

\section{5}

\section{Noble Boarding Schools}

The best-known Jesuit boarding schools were noble boarding schools, that is, schools restricted to boys and youths of proven noble rank. A ruler or a group of prominent local people sometimes founded a noble boarding school, then asked the Jesuits to operate it and provide instruction. As noted, the Jesuits wished to educate boys to become leaders of society who would act for the common good. Practically speaking, only noble boys might become leaders in seventeenth- and eighteenth-century Europe, the apex of the Old Regime. So, the Jesuits agreed to operate noble schools that offered perquisites and a richer curriculum than Jesuit day schools. The students were lay boys. If a boarder decided to become a clergyman, he usually reached high ecclesiastical office because he was a noble.

Italy had about fifteen noble boarding schools, plus others that only lasted a few years, and at least one citizen boarding school. ${ }^{112}$ The most important was the Saint Catherine College for Nobles (Collegio per Nobili di Santa Caterina) in Parma. ${ }^{113}$ Ranuccio I Farnese, duke of Parma and Piacenza (1569-1622, ruled for his father 1586, r.1592-1622), founded it in 1601, then awarded direction and teaching responsibilities to the local Jesuits in January 1604. It enrolled boys and youths of proven noble birth aged eleven to twenty who lived in a residence and attended Latin classes in the local Jesuit day school. The Ratio studiorum instruction at the day school was free; moreover, if noble boarders needed help,

112 This tentative list is the product of my research in progress. It includes Jesuit boarding schools for nobles in Bologna, Brescia, Ferrara, Genoa, Milan, Modena, Naples, Padua, Palermo, Parma, Prato, Ravenna, Siena, and Turin for certain. Pavone, "I gesuiti in Italia (1548-1773)," 363, provides a longer list that includes some boarding schools that lasted only a few years. Citizen boarding schools were also exclusive. In some Italian cities, citizen was a legal status that was lower than nobility but higher than that of commoners. For example, citizen status rendered a man eligible for certain governmental offices denied to the male population at large. And citizen merchants enjoyed some tax concessions.

113 Still useful is Gaetano Capasso, "Il Collegio dei Nobili di Parma: Memorie storiche pubblicate nel terzo centenario dalla sua fondazione (28 ottobre 1901)," Archivio storico per le provincie parmensi, n.s., 1 (1901): 1-285. See also Gian Paolo Brizzi, La formazione della classe dirigente nel Sei-Settecento: I seminaria nobilium nell'Italia centro-settentrionale (Bologna: Il Mulino, 1976), which studies the Jesuit noble schools at Bologna, Modena, Parma, and Siena; Miriam Turrini, Il 'giovine signore' in collegio: I gesuiti e l'educazione della nobiltà nelle consuetudini del collegio ducale di Parma (Bologna: CLUEB, 2006); and Il Collegio dei nobili di Parma: La formazione della classe dirigente (secoli XVII-XIX), Atti del Convegno nazionale, Fornovo, Sala Baganza, Fontevivo, 22-24 maggio 2008, a cura di Alba Mora (Parma: Monte Università Parma Editore, 2013). 
Jesuit scholastics tutored them in the residence. But this was only part of the education provided. The Jesuits hired laymen to teach riding, fencing, designing fortifications, vernacular languages, singing, dancing, and how to play musical instruments. In other words, the noble boys were taught skills and graces appropriate for court life, diplomacy, even military command. And the Parma school was known for its theatrical productions. Lay employees, who were de facto servants, provided for the physical needs and wishes of the boys.

The practices of the Italian noble schools accentuated the privileges of noble rank. Duke Ranuccio I and his successors showered favors on the noble boarders. They welcomed them to the court, gave them seats of honor at ducal functions, and invited them to hunt in the ducal park. The boarders wore uniforms. When they attended classes in the Jesuit day school, they were addressed by name and title, and were given the better seats, a practice endorsed by the Ratio studiorum. ${ }^{114}$ Parents paid high fees for the room, board, services, lessons in the non-Jesuit subjects, and the opportunity to bond with fellow nobles that their sons enjoyed. So far as can be determined, neither the Parma noble school nor any other Italian noble school enrolled students unable to pay fees.

The Parma school for nobles attracted an Italian and international student body. From sixty-four boarders in 1605 , it grew to a peak of 285 in 1700 , then steadily declined in the eighteenth century. For the years 1601 through 1770 , twenty-three percent of the students came from outside of Italy. ${ }^{115}$ After the suppression, direction of the Parma noble school was given to the Piarists (Poor Clerics Regular of the Mother of God of the Pious Schools), followed by other clergymen. None of them were able to arrest its decline, and it closed in 1830. The other Italian noble and citizen boarding schools were smaller than the Parma school. They typically began with fifty boarders in the first quarter of the seventeenth century, reached a peak of one hundred to 125 , but with few non-Italians, around 1700 , then declined to a handful in the third quarter of the eighteenth century. Only one survived the suppression. ${ }^{116}$

Another famous Jesuit noble boarding school was the Theresianum in Vienna. In 1746, Empress Maria Theresa of Austria (1717-80, r.1740-80) sold an imperial residence to the Jesuits of Vienna so that they might create a boarding

\footnotetext{
114 "Of course, he [the prefect of lower studies] should assign the better seats to those of noble families." Ratio studiorum, 123, paragraph 279; and Grendler, "Culture," 37-38.

115 ARSI, Venet. 105 II, fol. 550v; Capasso, "Il Collegio dei Nobili," 102; and Brizzi, Formazione, 38 .

116 This is based on some annual enrollment figures of the Bologna noble and citizen boarding schools as noted in Grendler, Jesuits and Italian Universities, 306; and extrapolation from the information in Brizzi, Formazione, 30-70. The Siena noble school continues today as a state boarding school.
} 
school for 140 noble boys. ${ }^{117}$ Its purpose was to educate boys for service to the Habsburg state. Under pressure from the imperial court, Jesuits taught all or most of the extraordinary or supplementary courses, that is, those not part of the Ratio studiorum. This was a major departure from Jesuit practice; for example, Jesuits did not teach the extraordinary courses in Italian noble boarding schools.

Because the Habsburg Empire was multilingual, vernacular languages were a major part of the curriculum of the Theresianum. It had nine teachers of French, three for Hungarian, at least two for German, two for Italian, and two for Czech. Jesuits taught most or all of these courses; for example, two Jesuits known for their publications on German literature taught German. And three Jesuits taught history: one taught the history of the medieval German empire, another taught political history, and a Hungarian Jesuit taught students how to use and evaluate manuscript sources. The Theresianum also taught geography, drawing, architecture, and economics and finances. Jesuit supervision was close: the students were divided into groups of ten and a Jesuit put in charge of each group. Overall, fifty-nine Jesuits taught or played some other role in the academic and spiritual formation of 140 boarders, an extraordinary personnel commitment by the Society. ${ }^{118}$ Today, the Theresianum is a state-run coeducational school with an international perspective and a focus on languages, but no Jesuit participation.

Other noble boarding schools in the Austrian Jesuit province imitated the Theresianum by emphasizing vernacular languages. Twenty Jesuits oversaw the education of ninety-two boarders in the noble boarding school at Nagyszombat in the Kingdom of Hungary (now Trnava in western Slovakia). It had four teachers of German, two for French, two for Hungarian, two for architecture, two for geometry, and one for geography, many of them Jesuits. Other boarding schools, both noble and non-noble, in what is now Austria, the Czech Republic, Hungary, Slovenia, and Croatia also offered extraordinary courses. ${ }^{119}$ The Jesuits governed many other noble boarding schools across Europe. But there is no European-wide census nor reliable provincial lists.

The boarding schools had the side effect of expanding the curriculum beyond the Ratio studiorum for students and teachers. Given the fact that Jesuits taught vernacular languages and other extraordinary courses in some noble boarding schools in the middle of the eighteenth century, one wonders if they

117 For what follows, see Szilas, "Austria. Antigua," 286, 289, which has additional bibliography.

118 Szilas, "Austria. Antigua," 286, 289.

119 Szilas, "Austria. Antigua," 289. 
would have broadened the curriculum of Jesuit day schools had the Society not been suppressed.

\section{Roman National Colleges}

A unique version of the Jesuit boarding school was the national college, which was a seminary for future secular priests from a specific linguistic region or political state in Europe. Historians usually call them national colleges, although they might also be called linguistic colleges or national seminaries. ${ }^{120}$ They educated young men for the priesthood so that they might return to their native lands to offer strong clerical leadership in Catholics lands lacking it, or to minister to persecuted Catholics, sometimes to suffer martyrdom. They were seminaries for secular clergymen rather than Jesuits. They were colleges, rather than schools or residences, because they lived on income from endowments, and had a church, such as a chapel in the building, for their exclusive use.

The most influential national colleges were located in Rome. The pope or a prelate founded and endowed a national college, then asked the Society of Jesus to govern it, a charge that the Jesuits willingly accepted. Promising youths from a foreign land demonstrating the desire to become priests were invited to Rome to live and study for free in the appropriate national college. They attended classes at the Roman College as day students and usually received supplemental tutoring in their colleges from Jesuit scholastics. A Jesuit rector and other Jesuits who normally lived in the college oversaw their spiritual development. At the conclusion of their studies, the seminarians were ordained and returned to their native lands. Many former students of the national colleges became bishops and a few became cardinals.

The first, largest, and most important Roman national college was the German College. ${ }^{121}$ In 1552, Cardinal Giovanni Morone (1509-8o, in office 1542-80), nuncio to the Holy Roman Empire, told Ignatius of Loyola and Pope Julius III

120 "National" is a term of convenience rather than historical precision. One cannot call England, France, Germany, or any other European political unit, a nation before the nineteenth century. States were empires, monarchies, duchies, or had some other political organization. They lacked the components of nationhood typical of nineteenth- and twentieth-century states.

121 The following account is based on Peter Schmidt, Das Collegium Germanicum in Rom und die Germaniker: Zur Funktion eines römischen Ausländerseminars (1552-1914) (Tübingen: Max Niemeyer, 1984); Cesareo, "Jesuit Colleges," 621-29; and Urban Fink, "Diego Laínez, das Collegium Germanicum und die Priesterausbildung zur Zeit des Trienter Konzils," in Diego Lainez (1512-1565) and His Generalate: Jesuit with Jewish Roots, Close Confidant of Ignatius of Loyola, Preeminent Theologian of the Council of Trent, ed. Paul Oberholzer, Bibliotheca Instituti Historici S.I. (Rome: Institutum Historicum Societatis Iesu, 2015), 76:819-36. 
$(1487-1555$, r.1550-55) that a college was needed to educate German youths for the priesthood. The project moved forward quickly. Julius III and various cardinals promised financial support, while Ignatius pledged that the Jesuits would govern the college. On August 31, 1552, Julius III issued a bull founding the German College. The college promised to accept German priesthood candidates aged sixteen through twenty-one possessing good health, talent, and good character who would attend Roman College classes. By 1554, the German College had sixty students from German-speaking northern Europe. ${ }^{122}$

However, the initial endowment was inadequate and enrollment dwindled. In order to remain open, the German College accepted paying lay students, mostly Italian noble boys younger than fifteen, who had no intention of becoming priests or moving to Germany, and sometimes behaved badly. ${ }^{123}$ In the 1560 s and early 1570s, enrollment rose to about two hundred, but only about ten percent were German seminarians.

Pope Gregory XIII came to the rescue in 1573 . He decreed that the German College would enroll no fewer than one hundred students from Germany and its neighbors. To make this financially possible, he bestowed on it additional benefices that generated much more income. He then created a Hungarian College in 1579. When it attracted few students, he merged it with the German College in 1580, thus creating the German-Hungarian College. The lay boarders were eased out and the German-Hungarian College fulfilled its original purpose. It produced several thousand clergymen, including a few cardinals, many bishops, seminary professors, canons, and abbots of major monasteries. Although some graduates of the German-Hungarian College engaged in missionary activity in Protestant states in central and eastern Europe and a handful were killed, the primary purpose of the German-Hungarian College was to strengthen the Catholic Church in Germany and Hungary.

By contrast, the goal of the Venerable English College, the Scots College Rome, and the Irish College, all located in Rome, was to train English, Scottish, and Irish secular priests who would return to their native lands as missionaries to persecuted Catholics at considerable risk to themselves and their hosts. Catholic priests from the British Isles had to be educated on the continent

\footnotetext{
122 "At the start of this year [1554], the German College was flourishing quite well. Pope Julius III and the cardinals paid the expenses of its sixty [students]; but Father Ignatius wrote to Louvain, Cologne, and Vienna, [asking] them to send still more students [...]"; Year by Year with the Early Jesuits (1537-1556): Selections from the Chronicon of Juan de Polanco S.J., trans. John Patrick Donnelly (St. Louis: Institute of Jesuit Sources, 2004), 315.

123 There are many documents in the Mon. paed., nova editio, concerning the German-Hungarian College in its first decades. For translations of four of them, including sharp assessments of the behavior of students, see Jesuit Pedagogy, 93-155.
} 
because the Catholic Church was outlawed in England and Scotland, while English laws forbade all Irish citizens from studying either at home or abroad. Consequently, small colleges - simply small residences in many cases-were established in university towns across Europe, especially in Spain, each for a handful of English, Scottish, and Irish priesthood students. ${ }^{124}$ However, the English, Scots, and Irish national colleges in Rome governed by the Jesuits were the most important.

Urged by English Catholic exiles, Gregory XIII founded the English College in 1576 , locating it in a medieval hospice for English pilgrims, now nearly empty because of Henry VIII's (1491-1547, r.1509-47) break with Rome. The purpose of the English College was to prepare Englishmen to be missionaries to return to England and Wales. The pope appointed an Englishman as rector. However, on the request of the pope and Cardinal Giovanni Morone, a reluctant superior general Everard Mercurian (1514-80, in office 1573-80) appointed a Jesuit to serve as spiritual director and another as prefect of studies on a temporary basis. In early 1579 , the students successfully petitioned the pope to give complete direction of the college to the Jesuits because they believed that the Jesuits would do a better job of preparing them for their missionary labor. The students attended classes at the Roman College. Although the English College inherited the adjective "Venerable" from the medieval hospice, it became firmly attached to the English College as a result of the martyrdoms of forty-four alumni between 1581 and $1679 .{ }^{125}$

Pope Clement VIII (1536-1605, r.1592-1605) founded the Scots College Rome in 1602 and named a papal official rector, while the students attended classes at the Roman College. When the papal official died, the students petitioned that the Jesuits be given charge of the college, which occurred in 1615 . The Jesuits then governed it until the suppression. ${ }^{126}$ An Irish Franciscan and Cardinal Ludovico Ludovisi (1595-1632, in office 1621-32) jointly founded the Irish College in Rome in 1628. Irish Franciscans, the largest religious order in Ireland, governed the college, and the students attended classes at the Roman College.

124 For example, see the list of twenty-nine Irish colleges on the continent founded in the sixteenth and seventeenth centuries, six of them governed by the Jesuits and five by the Franciscans, in Patricia O Connell, The Irish College at Santiago de Compostela 1605-1769 (Dublin: Four Courts Press, 2007), 25-27. See also Michael E. Williams, St. Alban's College Valladolid: Four Centuries of English Catholic Presence in Spain (London: Hurst, 1986).

125 Michael E. Williams, "Colegio Inglés de Roma," $D H C J$, 1:845-46; Cesareo, "Jesuit Colleges in Rome," 629-37; and Michael E. Williams, The Venerable English College Rome: A History, 2nd ed. (Leominster: Gracewing, 2008), xvii, 1-8, 290-91.

126 Mark Dilworth, "Beginnings 1600-1707," and James F. McMillan, "Development 1707-1820," in The Scots College Rome 1600-200o, ed. Raymond McCluskey (Edinburgh: John Donald, 2000), $1-18$ and $19-42$. 
When Cardinal Ludovisi died in 1632, his will provided generously for the Irish College but insisted that governance must be given to the Jesuits. After a legal challenge was overcome, this happened on February 8, 1635. The Jesuits governed the Irish College until the suppression. ${ }^{127}$

The three colleges had common goals, profiles, and difficulties. ${ }^{128}$ (A proposal that the three colleges be united or at least work together went nowhere.) All three had pontifical charters and received papal financial support. All functioned as seminaries preparing secular priests as missionaries. They did not train Jesuit missionaries, who were educated in Jesuit houses. The students were normally between seventeen and twenty-five years of age and academically ready for philosophy classes. They were small; the average number of students in residence was probably around ten, and sometimes lower, in the seventeenth and eighteenth centuries. Students were required to sign a missionary oath that they would return to their native lands as missionaries. Instead, many students joined religious orders, including the Jesuits, with the result that the colleges produced few missionaries. So, the oath was strengthened. For example, in the middle of the seventeenth century students at the Scots College Rome were required to serve three years in the Scottish mission as secular clergymen before they might join religious orders. This produced fewer students, which did not benefit the college or the mission. ${ }^{129}$ Nevertheless, over time a larger percentage of the students in the three colleges did become missionaries.

Several criticisms were leveled against the national colleges and the Society. The Jesuits were accused of using their position to recruit men into the Society. The charge is difficult to confirm or deny, because students joined other religious orders as well. There were complaints that the philosophy and theology classes at the Roman College were more suited for academic careers than for missionary life. Rector appointments were sometimes contentious: Would an English, Scot, or Irish rector, or an Italian Jesuit rector, best serve the college? There was no definitive answer, because there were dedicated and effective rectors, as well as weak and inadequate rectors, on both sides of the native-son fence. Finally, divisions in the Catholic communities in England, Ireland, and Scotland spilled over into the national colleges in Rome, producing a certain amount of strife.

127 Patrick J. Corish, "The Beginnings of the Irish College, Rome," in The Irish College, Rome, and Its World, ed. Dáire Keogh and Albert McDonnell (Dublin: Four Courts Press, 2008), 1-13.

128 This and the following paragraph are based on the bibliography in the previous four notes.

129 Dilworth, "Beginnings," 29-30. 
Three more national colleges governed by the Jesuits trained secular priests for the other end of Europe and the Middle East. In 1577, Pope Gregory XIII founded the Greek College in order to educate young Greeks to become Latin-rite clergymen in Greek-speaking lands ruled by the Turks and islands ruled by Venice, in both of which the Greek Orthodox Church was strong. ${ }^{130}$ It had twenty-five to sixty boarders. Cardinal protectors who oversaw the Greek College chose secular priests, the Jesuits from 1591 to 1604 , the Somaschans, and then the Dominicans to govern the college. However, the boarders were unhappy about the quality of their education and other matters.

Then in 1621 a new group of cardinal protectors led by Cardinal Ludovisi decided that the Jesuits would assume direction of the college. About a third of the boarders were Venetian subjects, and the Venetian government strongly objected. The papal nuncio to Venice defended the decision on the grounds that the Jesuits had no equals in education. The Venetian Senate asked Paolo Sarpi (1552-1623), an anti-papal Servite friar who advised the Senate on theological and canon law matters, to draft a response. Sarpi subverted the nuncio's praise: the Jesuits had no equals in promoting education that alienated students from their obligations to father, patria, and civil ruler. Instead, they turned the student's love and obedience toward a spiritual father, such as the pope. It was a rhetorical version of a common accusation against the Jesuits. The cardinal protectors ignored the Venetian protest and in 1622 gave direction of the Greek College to the Society, who governed the Greek College until $1773 .{ }^{131}$

Gregory XIII created the Maronite College in 1584 in order to educate clergy for the Maronite Church. Founded by St. Maroun (born in Antioch, d.410), a monk who established a monastery in Syria, the Maronites (the Syriac Maronite Church of Antioch) are an eastern rite Catholic church in union with the papacy. The majority of Maronites lived then and live today in Lebanon. The pope gave direction of the Maronite College to the Jesuits, and the students attended classes at the Roman College. The college was small, had limited financial resources, and saw some of its alumni become Jesuits and Dominicans. Nevertheless, it educated six Maronite patriarchs and thirty bishops until the Jesuits were suppressed. ${ }^{132}$

Gregory XIII also founded the Illyrian College in 1581 to educate priests who spoke Slavic languages and would serve Catholics in Dalmatia and the Balkans.

\footnotetext{
130 Jan Krajcar, "Colegio Griego, Roma," DHCJ, 1:842-43.

131 For Sarpi's comments, see Grendler, Jesuits and Italian Universities, 148-50. The Republic of Venice had expelled the Jesuits in 1606 and did not allow them to return until 1657 .

132 Vincenzo Poggi, "Colegio Maronita," DHCJ, 1:846-48.
} 
He located it in Loreto, very close to the Adriatic Sea, and gave direction to the Jesuits. Its capacity was thirty seminarians who attended classes at the Jesuit day school in Loreto. Clement VIII moved it to Rome in 1593 and gave direction to the Somaschans. However, in response to repeated petitions from bishops of Dalmatia and Ottoman-ruled lands, Pope Urban viII (1568-1644, r.1623-44) moved it back to Loreto in 1624 and restored direction to the Jesuits, who governed it until $1773 \cdot{ }^{133}$

\section{Jesuit Schools in France}

Although boarding schools and national colleges were important, the heart of Jesuit education was the network of day schools supported by civil authorities in the major Catholic states of Europe. For reasons of space, it is not possible to discuss Jesuit schools everywhere. But a closer look at the schools in France illuminates their place in the most powerful European monarchy at that time. Listing the schools with their foundation dates shows the ebb and flow of Jesuit education. And describing the attitude of the monarchy toward the Society demonstrates how much it affected the Jesuit educational ministry in France.

What follows is a list of all the schools, including boarding schools, in the five Jesuit provinces of the French assistancy: France (also called Paris), Aquitaine, Lyon, Toulouse, and Champagne. The date on the left indicates the year in which a school opened. In almost all cases, the school opened in the year that the college in which it was located was founded. A few Jesuit residences had schools and these are included; again, the date given is the year in which the school began. All Jesuit schools taught continuously until the Society was suppressed in France in 1762, except when the Jesuits were temporarily expelled from some towns in the late sixteenth century. The years in which schools were closed are indicated. The list includes the unique diocesan seminary school at Luçon, where the Jesuits had to create a seminary day school because there was no Jesuit day school in the town. Schools in the overseas missions in Canada, the Middle East, and elsewhere governed by French Jesuit provinces are not included. A handful of national seminaries that prepared Englishmen, Irish, and Scots for missions to England, Ireland, and Scotland are also excluded. The list of schools is based on the articles on individual French colleges in Les établissements des jésuites en France.

133 Miko Korade, “Colegio Ilírico de Loreto," $D H C J$, 1:843-44. 


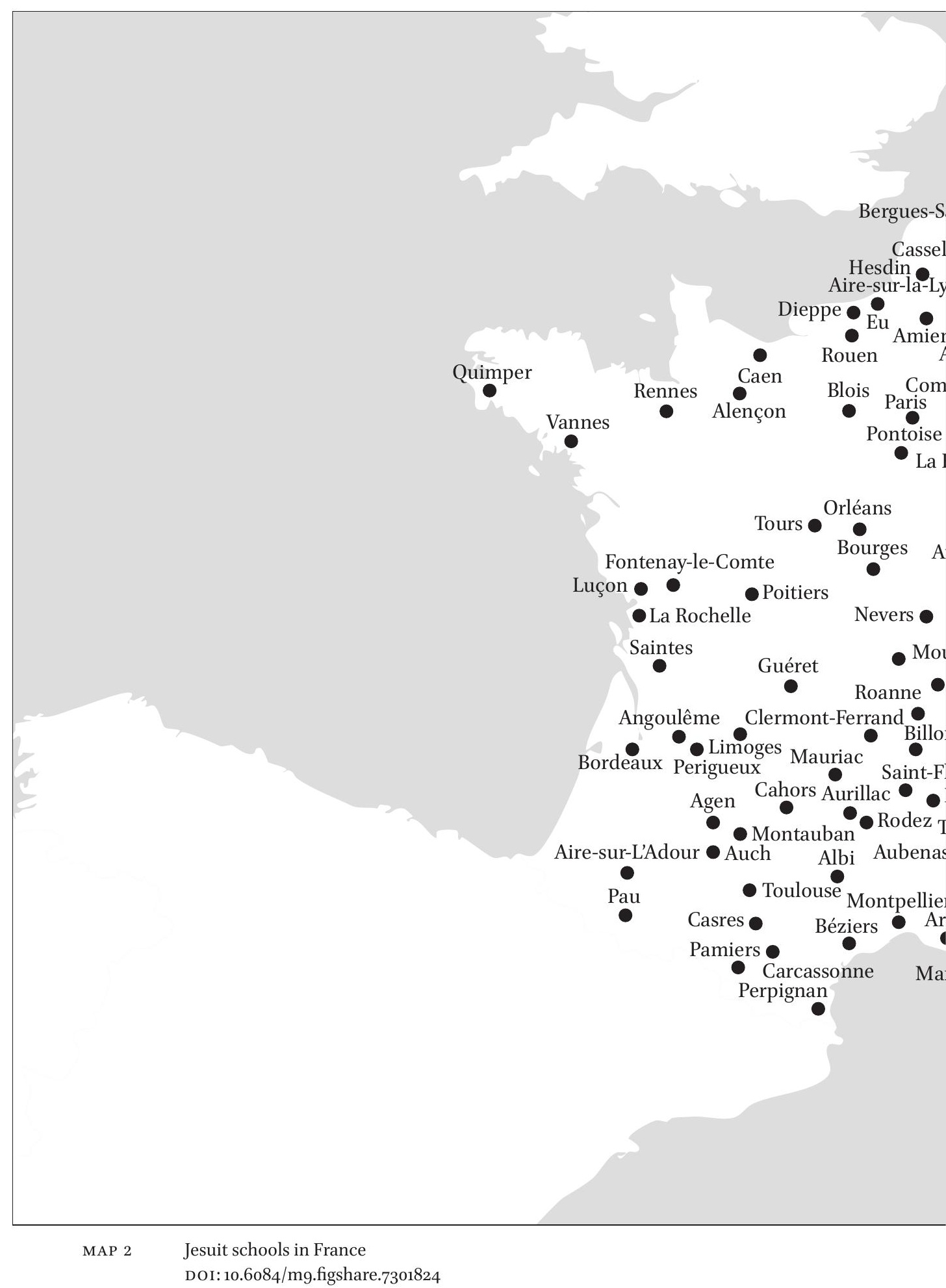




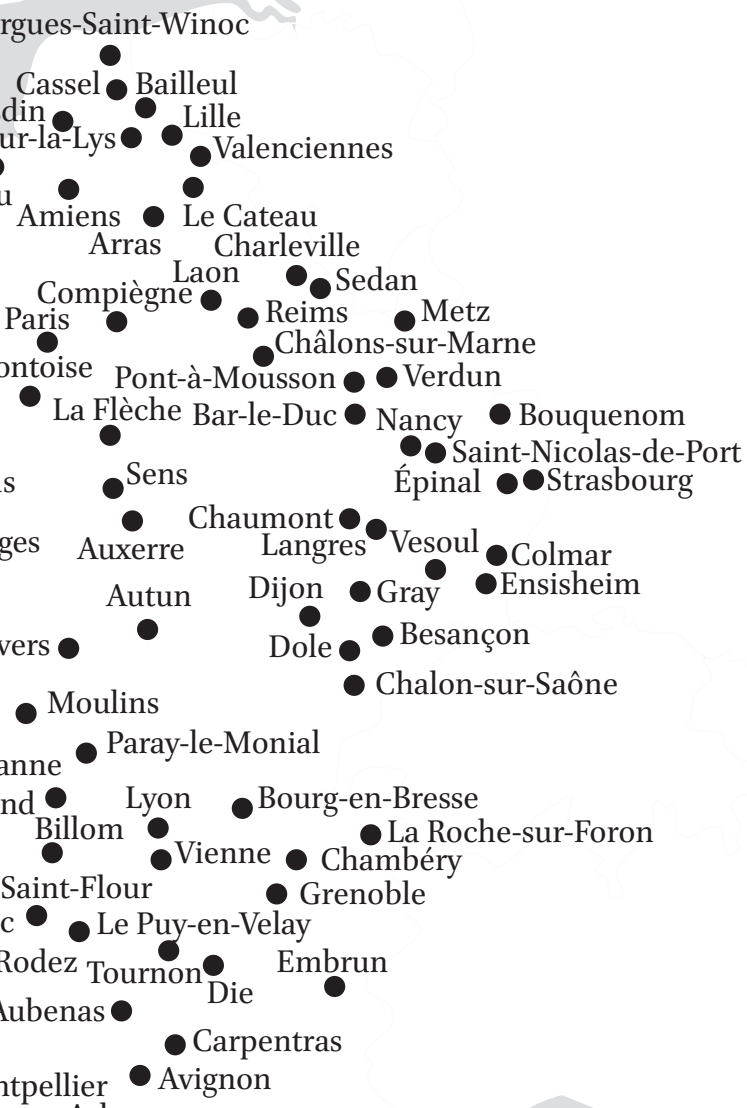


1558 Billom to 1593 , reopens 1604

1559 Pamiers to 1561 , reopens 1630

156 o Paris to 1595 , reopens $1605 / 18^{\text {a }}$ plus boarding school in 1609

Mauriac to 1595 , reopens 1605

1561 Tournon college and Jesuit university

1562 Rodez

Toulouse plus boarding school in 1691

1564 Verdun

1565 Avignon

Chambéry

Lyon to 1595 , reopens 1604 plus boarding school

Rouen to 1595 , reopens 1604

1571 Bar-le-Duc

1572 Bordeaux to 1589 , reopens 1603 plus boarding school

Nevers to 1594 , reopens 1607

1574 Pont-à-Mousson school, Jesuit university, and boarding school

1575 Bourges to 1595 , reopens 1604 plus boarding school 1604

1581 Dijon to 1595 , reopens 1603

Eu to 1594 , reopens 1607

1582 Dole

Embrun to 1585 , reopens 1604

1585 Valenciennes

1588 Le Puy-en-Velay

1590 Auch

1591 Agen

Perigueux

1592 Lille

1597 Besançon

Limoges

1599 Béziers royal college

1600 Perpignan plus boarding school in 1660

Bergues-Saint-Winoc

1603 Arras plus boarding school in 1716

Aubenas

La Flèche royal college plus boarding school in 1604 
1604 Amiens

Cahors

Rennes

Vienne royal college

1606 Reims plus boarding school in 1608

1607 Carpentras

Poitiers royal college plus boarding school in 1688

1609 Caen

1610 Moulins

Vesoul

1611 Angoulême plus boarding school in 1668

Roanne

Saintes

1612 Aire-sur-la-Lys

Charleville

1613 Hesdin

1614 Ensisheim

Pontoise

1616 Marseille plus boarding school in 1729

Nancy

1617 Bailleul

Orléans royal college

1618 Autun

Cassel

Châlons-sur-Marne (renamed Châlons-sur-Champagne in 1998)

Chaumont

1619 Aurillac

1620 Quimper

1621 Aix-en-Provence royal college plus boarding school 1684

Béthune

Langres

1622 Auxerre

Gray

Grenoble royal college plus boarding school 1729

Metz

Pau 
1623 Albi

Alençon royal college

Blois

Bourg-en-Bresse

Carcassonne

Sens

1626 Montpellier

1628 Colmar 1628-32, 1698-1765

La Roche-sur-Foron 1628-1712

1629 La Rochelle royal college

1630 Bouquenom

Vannes

1631 Saint-Nicolas-de-Port 1631-c.1645, 1753-68

1633 Épinal

Sedan royal college

Paray-le-Monial

1634 Chalon-sur-Saône

Clermont-Ferrand plus boarding school 1741

Dieppe

Montauban royal college

1635 Tours

1637 Fontenay-le-Comte

1639 Arles

1643 Saint-Flour

1653 Compiègne royal college

1664 Casres

1685 Strasbourg

Toulon

1696 Die

1699 Luçon seminary school

1712 Aire-sur-L'Adour only to 1714

1716 Le Cateau plus boarding school in 1759

1723 Guéret only theology 1723-32

1730 Laon

a Although some Jesuits returned in 1605 , and the Jesuits were allowed to teach theology in 1609, they were not permitted to teach all subjects until 1618 . 
There were 104 Jesuit schools in France, three of which had upper schools chartered as universities. Seventeen Jesuit colleges added boarding schools, sometimes years later. A closer look at the foundation dates of the schools reveals rapid growth, then extraordinary growth, followed by stasis:

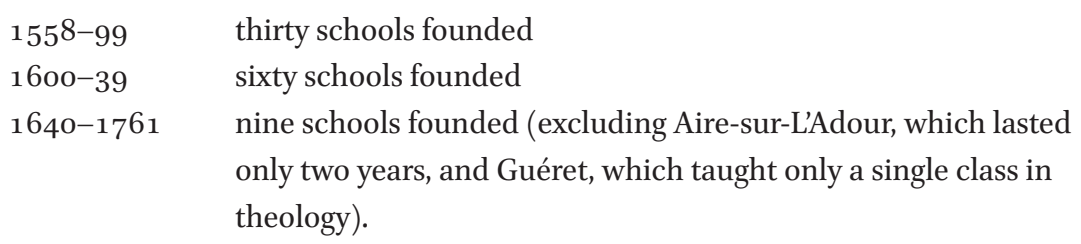

In the forty-two years from 1558 through 1599, the Jesuits founded two schools in every three years. In the forty years from 1600 through 1639 , the rate of school foundations doubled to about three new schools in two years. But then from 1640 through 1761 , the Jesuits founded only nine complete schools that endured more than two years, a rate of only one every thirteen and onehalf years.

In their first forty years in France, the Jesuits were a new order that brought fresh energy and hope to French Catholics at a time of militant Protestantism and civil war. ${ }^{134}$ The Jesuits initially benefited substantially from the encouragement and support of several French cardinals who invited them to establish colleges with schools across France, sometimes in places threatened by the Huguenots, that is, French Calvinists. The weakness of the monarchy and its preoccupation with threats to its existence afforded the cardinals considerable independence of action. While not every cardinal delivered all the funding promised, their invitations enabled the Jesuits to establish themselves. Support from city councils and donors, which came as local people approved of the Jesuit teaching and other ministries, did the rest. The number of Jesuits in many colleges was not large; hence, few Jesuit schools outside of Paris had more than three to five classes.

The Jesuits were not officially recognized in France until 1561 and 1562, even though they had already founded four colleges with schools. And because of objections from Gallican bishops and the Parlement of Paris, the Jesuits were

134 For the following historical survey, see Fouqueray, Histoire; the articles in Les établissements en France; Paul Duclos, "Francia," DHCJ, 2:1498-1508; and A. Lynn Martin, "The Jesuit Mission to France," in Mercurian Project, 249-93. Édouard Piaget, Histoire de l'établissement des jésuites en France (1540-1640) (Leiden: Brill, 1893), is still useful. 
not given the status of a religious order, but only that of a corporation and college under the name Society of the College of Clermont, which was the Jesuit college in Paris. Their constitutions were not registered, they were placed under the jurisdiction of bishops, and they were forbidden to appeal to papal bulls in disputes. ${ }^{135}$ Enemies of the Jesuits will later exploit their lack of the customary rights and privileges of religious orders.

Despite this handicap, from 1560 to the mid-159os the Jesuits founded colleges and schools in the midst of the French Wars of Religion (1562-98), which were simultaneously a Catholic-Protestant conflict and a civil war pitting noble factions against the monarchy. During the climactic years of the wars around 1589, Superior General Claudio Acquaviva ordered French Jesuits not to take political sides and was reluctantly obeyed. The Jesuits were welcomed as stalwart champions of Catholicism against Protestantism.

Support from cardinals and the threat of heresy were not the only reasons that the French welcomed Jesuit schools. Sixteenth-century France had hundreds of municipal public schools, meaning schools under the supervision of city councils, which chose the teachers and paid their salaries. Municipal schools taught reading and writing, followed by the humanities curriculum and, often, Aristotelian logic and philosophy. ${ }^{136}$ But financial costs were high and the time needed to oversee the schools burdensome, at a time when the costs of defense were rising, and city councils had many other duties. Cities listened as the well-educated and pedagogically skilled Jesuits offered to teach the same curriculum at less expense, and without charging tuition to the students. The result was that many municipal schools became Jesuit schools. ${ }^{137}$

As always in French history, what happened in Paris mattered a great deal. It was the political, religious, and cultural capital of the country, and the home of the university in which the first ten Jesuits had created the Society of Jesus. But the university did not look favorably on the creation of their alumni. Instead, the university and the Parlement of Paris waged a determined fight to drive the Jesuits out of France and partially succeeded. On December 27, 1594, a twenty-year-old law student, who had studied philosophy with the Jesuits for about two and one-half years, tried to assassinate Henry IV (born Henry of Navarre, 1553-1610, r.1589-1610). On the spurious grounds that the Jesuits were complicit in the assassination attempt (which the would-be assassin denied under severe torture), within hours the Parlement of Paris expelled the Jesuits

\footnotetext{
135 Fouqueray, Histoire, 1:243-57; Bangert, History, 68-69; and O'Malley, First Jesuits, 287-90.

136 George Huppert, Public Schools in Renaissance France (Urbana, IL: University of Illinois Press, 1984), 1-103.

137 Huppert, Public Schools, 104-110.
} 
from the territories under its jurisdiction and urged other parlements to do the same. To make matters worse, a Paris Jesuit found in possession of materials advocating regicide was hanged in January 1595 . However, Henry IV conspicuously did not issue a royal edict confirming expulsion. Hence, most parlements elsewhere in France did not follow the lead of the Parlement of Paris. While some Jesuit schools closed their doors, the majority did not. The pace of Jesuit foundations slowed but did not stop. ${ }^{138}$

Henry IV was a Huguenot who became a Catholic in July 1593, which caused the civil conflict to subside. As he solidified control of the country, Henry signaled his support of Jesuit schools. This culminated with promulgation of the Edict of Rouen of September 1, 1603, that formally and legally reestablished the Jesuits in France. To make his policy crystal clear, he gave his name and financial support to a new Jesuit college and school in La Flèche, a town from which the Parlement of Paris had barred the Jesuits. ${ }^{139}$ It became the best-known Jesuit school in France, whose boarding school many famous figures attended. As Henry IV showed his support for the Jesuits, more and more towns petitioned the Jesuits to come and replace their teachers. Although city councils told the Jesuits that they wanted them to maintain Catholicism, to check heresy, and to educate youth well, financial considerations and the desire to curry royal favor were also persuasive. ${ }^{140}$

Although the Edict of Rouen did not expand the legal rights of the Jesuits beyond those granted in 1561 and 1562 , it authorized the king to overrule its provisions if he wished. The edict also mandated royal approval for all new Jesuit foundations and insisted that Jesuits swear an oath of loyalty to the crown, which they eventually did, after Superior General Acquaviva gave cautious approval. The Edict of Rouen and Henry IV's actions accomplished three things. They brought all of French education under ultimate royal control, they greatly encouraged Jesuit schools, and they rendered the Jesuits dependent on royal favor. ${ }^{141}$

138 For the attempted assassination and the aftermath, see Piaget, Histoire, 187-220; Fouqueray, Histoire, 2:344-438; Pierre Delattre, "Paris: Le Collège," in Les établissements en France, 3:1129-36; Roland Mousnier, The Assassination of Henry IV: The Tyrannicide Problem and the Consolidation of the French Absolute Monarchy in the Early Seventeenth Century, trans. Joan Spencer (New York: Charles Scribner's Sons, 1973), 217-24; and Eric Nelson, The Jesuits and the Monarchy, Catholic Reform and Political Authority in France (1590-1615) (Aldershot: Ashgate, 2005), 11-55.

139 Paul Mazin, "La Flèche," in Les établissements en France, 2:903-20.

140 Paul Bailly, "Collèges," in Les établissements en France, 1:1438.

141 Eric Nelson summarizes the situation well: "Prior to its promulgation in 1603, no French monarch had founded a Jesuit college; henceforth, however, new foundations would be linked to the monarchy. Royal support and patronage drove the rapid proliferation of Jesuit 
Which they had in abundance for nearly forty years. The number of new foundations with schools accelerated at an amazing pace through the rest of the reign of Henry IV and that of Louis XIII (1601-43, r.1610-43), which Queen Mother Marie de Médicis (1575-1642) and Cardinal Richelieu (Armand Jean du Plessis, 1585-1642) dominated. Several more new colleges and schools were designated as royal, meaning that a member of the royal family had bestowed his or her name and a financial contribution on it. Because the Society added many new members in these years, the French provinces were able to staff the new schools.

After the extraordinary expansion to the 1640 , the Jesuits then nearly stopped founding new schools. One reason is that they diverted some of their human resources to the expansion of existing schools. Between 1660 and 1759, they added ten boarding schools in towns that already had Jesuit day schools. As was the case elsewhere, the boarders attended the day school for the Latin subjects, then studied vernacular languages, fencing, riding, music, and dancing with lay teachers. ${ }^{142}$

And the Jesuits accepted the direction of diocesan seminaries. When Louis XIV (1638-1715, r.1643-1715) conquered Strasbourg, part of Alsace, in 1681, he wanted to ensure that the Strasbourg clergy would become religiously, culturally, and politically French. Hence, he asked French Jesuits to take charge of the spiritual and educational preparation of the Strasbourg diocesan clergy. He might have invited the Oratorians, but he saw them as tainted by Jansenism. To this date, the French Jesuits had only reluctantly accepted the direction of diocesan seminaries, because they did not wish to divert their priests from other ministries, and they did not wish to share authority over seminaries with bishops. In 1626, for example, they directed only two diocesan seminaries, Metz and Rouen. ${ }^{143}$ But now the king had requested their services. Hence, the five French Jesuit provinces asked the Twelfth General Congregation, which met from June to September 1682, for permission to accept this new charge. The general congregation warmly endorsed the request. With royal financial support-the French crown agreed to support financially twenty-eight

colleges which ultimately made the Jesuits the chief educators of the seventeenth-century French Catholic elite." Nelson, Jesuits and the Monarchy, 57-145, quote at 113. See also Fouqueray, Histoire, 2:637-90.

142 It is unclear whether enrollment was restricted to noble students. In any case, the fees of the French boarding schools were high enough that only wealthy students were able to attend.

143 Delattre, "Introduction," 1:xi. 
seminarians - in 1683 the Jesuits signed a contract to supervise and teach candidates for the priesthood in the diocesan seminary of Strasbourg. ${ }^{144}$

With this sign of royal preference and Jesuit willingness, eighteen more bishops asked the Jesuits to operate their seminaries between 1683 and 1730, sixteen of them during the rest of the reign of Louis XIV. The Jesuits either created a diocesan seminary where none had previously existed, or they replaced secular clergymen or another religious order that had previously operated the seminary. In all but one town, the Jesuits already had a school; hence, the seminarians attended the existing Jesuit day school. But the seminaries did require the services of additional Jesuits: a rector, spiritual director, and often one or two more Jesuits. Sometimes, the existing Jesuit day school added more instruction in philosophy and theology for the seminarians, which meant they needed more teachers. In Luçon, where they had no school, the Jesuits created a school without founding a residence or college, a unique occurrence. ${ }^{145}$

Nevertheless, the most important reason for the near halt of new Jesuit school foundations was the rise of new French teaching orders, all of whom taught for free. The first new order was Les Pères de la Doctrine Chrétienne, the Fathers of the Christian Doctrine, most often called Doctrinaires. César de Bus (1544-1607), a secular priest, and his associates founded them in Avignon in 1592, and they received papal approval in 1597. Initially intended to teach Christian doctrine only, they founded a regular school in Brive in 1619 and had twenty-five schools by 1690 . They added only two more schools by 1760 , in part because some Doctrinaires favored Jansenism, which the monarchy opposed. ${ }^{146}$

In 1611, Pierre de Bérulle (1575-1629) created the Oratoire de France or Congregatio Oratorii Iesu et Mariae (Congregation of the Oratory of Jesus and Mary Immaculate). They are usually called the French Oratory or Oratorians in order to differentiate them from the Italian Congregation of the Oratory founded by St. Philip Neri (1515-95) in 1575 The French Oratorians received papal approval in 1611 and opened their first school in 1614 at Dieppe. They operated more than fifty schools, seminaries, and/or parishes in France by 1629, and more followed. ${ }^{147}$

\footnotetext{
144 Pierre Delattre, "Séminaires," in Les établissements en France, 4:1063-65; and Padberg, O'Keefe, and McCarthy, For Matters of Greater Moment, 341-42.

145 Delattre, "Introduction," 1:xi; Delattre, "Séminaires," 4:1063-76.

146 The fundamental study is Jean de Viguerie, Une oeuvre d'éducation sous l'ancien régime: Les Pères de la doctrine chrétienne en France et en Italie 1592-1792 (Paris: Les Éditions de la Nouvelle Aurore, 1976). See also Carlo Rista, "Bus, César de," DIP, 1:1681-83; Carlo Rista, "Dottrinari di Avignone," DIP, 3:975-77.

147 Michel Join-Lambert, "Bérulle, Pierre de," DIP, 1:1407-9; and Pierre Clavel, "Oratorio di Gesù e di Maria Immacolata," DIP, 6:776-80.
} 
The Frères des écoles chrétiennes (Fratres Scholarum Christianarum, or the Brothers of the Christian Schools or De La Salle Brothers in English) were the largest and most important new French teaching order. ${ }^{148}$ In 1658 , two priests in Rouen and their followers began to create free schools in Rouen, Guise, and Laon. In 1679, they met Jean-Baptiste de la Salle (1651-1719) who became the charismatic leader of a growing number of French religious dedicated to teaching. They received papal approval in 1725 and expanded rapidly. In 1717, 102 Brothers staffed twenty-two schools that educated 9,300 boys; in 1751, 523 Brothers staffed 102 schools that educated 19,275 boys. ${ }^{149}$ The number of Christian Brother schools was approximately the same as the number of Jesuit schools in 1751.

The schools of the new French teaching orders were both similar and different from Jesuit day schools. Like the Jesuits, they taught humanistic studies, their upper schools initially taught Aristotelian philosophy, and they taught for free. But they were different as well. The Brothers of the Christian Schools began with an ABC course. (Whether French Jesuit schools sponsored ABC classes taught by non-Jesuits has not been investigated.) They introduced French literature. They were more open to Cartesianism, the scientific and mathematically oriented philosophy of René Descartes (1596-1650). Indeed, the Doctrinaires underwent a curricular conversion from Aristotelianism to Cartesianism between 1711 and $1713 .{ }^{150}$ And because the new orders were founded in France by Frenchmen, they were not seen as a foreign order whose members owed primary allegiance to a foreign sovereign, the pope.

The French Society of Jesus stopped growing. In 1716, there were 3,109 Jesuits in the five French provinces; in 1761 , there were $3,074 \cdot{ }^{151}$ It is very likely that the French teaching orders attracted devout Frenchmen with academic skills and ambitions who otherwise would have become Jesuits. Far worse, school enrollments declined sharply from the seventeenth to the eighteenth century. For example, in 1629 the total school enrollment of the Jesuit province of Champagne was 5,678 ; in 1761 , it had fallen to $3,021 .^{152}$ In addition to the competition from new religious order schools, Jesuit loyalty to the Ratio studiorum probably played a role. Some parents wanted their sons to study French literature and

\footnotetext{
148 They have no connection with the Congregation of Christian Brothers founded in Ireland in 1802 .

149 Maurice-Alphonse Hermans, "Giovanni Battista de la Salle," DIP, 4:1237-43; Hermans, "Fratelli delle Scuole Cristiane," DIP, 4:729-46, esp. 742; and Yves Poutet, "Fratelli delle Scuole Cristiane e di Carità," DIP, 4:746-47.

150 Viguerie, Une oeuvre d'éducation, 545-54.

151 Duclos, "Francia," 1502.

152 Dainville, L'éducation des jésuites, 82-83; repeated in Bangert, History of the Jesuits, 309.
} 
Cartesianism. But while some individual Jesuits avidly read Descartes, the Society as a whole stayed with Aristotelianism. ${ }^{153}$

A lethal combination of the example of Portugal, determined enemies, Gallicanism, and the constitutional weakness of the French Jesuits produced the French suppression. Philosophes determined to drive the church out of education had prepared elite public opinion for the elimination of Jesuit schools. The ruthless suppression, marked by mendacity and trumped-up charges, in Portugal in 1759 showed how easily the Jesuits could be destroyed. A financial scandal offered the opportunity to attack them in France, and the Jansenists, always bitter enemies of the Jesuits, played a key role. Even though the French Jesuits had time and again, either fulsomely or with reservations, endorsed the independence of the French church from the papacy, the Parlement of Paris still found them insufficiently Gallican. Relying on charges lacking much legal substance, it seized on the precarious legal position of the Jesuits in France to act. On April 1, 1762, the Parlement of Paris ordered all Jesuit schools closed and the Society dissolved. A weak and feckless Louis XV (1710-74, r.1715-74) then abandoned the Jesuits by endorsing the action of Parlement. ${ }^{154}$ The schools were closed, or were given to city governments, or to the new French religious orders; 113 Jesuits departed La Flèche on April 1, 1762, and the school became a military academy, then was given to the Doctrinaires in $1784 .{ }^{155}$ They did not rule it for long, because in a few years the French Revolution swept away all religious schools and orders, in the course of which many former Jesuits and members of other religious orders were murdered.

The French story displayed some common elements of Jesuit schools in Europe. The Jesuits had a great number of schools in France including the same mix of day schools, boarding schools, and seminaries found elsewhere in Europe. Their schools enjoyed considerable support from civic officials and local

153 Delattre, "Collèges," in Les établissements en France, 1:1451-52; and Bangert, History, 307-9. However, this is a topic meriting additional research.

154 Since this is a study of Jesuit schools, only a few studies of the suppression in France are listed. Bangert, History, 297-319, 372-83, offers an English summary; and Duclos, "Francia," 1502-4, provides a Spanish summary. See also Dale Van Kley, The Jansenists and the Expulsion of the Jesuits from France 1757-1765 (New Haven: Yale University Press, 1975); Van Kley, "Plots and Rumors of Plots: The Role of Conspiracy in the International Campaign against the Society of Jesus, 1758-1768," in The Jesuit Suppression in Global Context: Causes, Events, and Consequences, ed. Jeffrey D. Burson and Jonathan Wright (Cambridge: Cambridge University Press, 2015), 13-39; Jeffrey D. Burson, "Between Power and Enlightenment: The Cultural and Intellectual Context for the Jesuit Suppression in France," in Burson and Wright, Jesuit Suppression in Global Context, 40-64; and D. Gillian Thompson, "French Jesuits 1756-1814," in Burson and Wright, Jesuit Suppression in Global Context, 181-98.

Paul Mazin, "La Flèche," in Les établissements en France, 2:914. 
people. The Society also attracted powerful enemies because it was considered insufficiently Gallican. The schools flourished until French teaching orders and their schools became effective competitors. Perhaps most important, the Society and its schools were heavily dependent on the favor of the monarchy. They flourished when Henry IV and Louis XIV favored them, but were suppressed when the monarchy withdrew support.

\section{Jesuit Schools: Conclusions}

Jesuit schools began when Ignatius of Loyola accepted an invitation to found a school in Messina. It flourished and was followed by others, most notably the Roman College. Diego Laínez, the second superior general of the Society, then decided that the schools would be the most important ministry of the Society. He mandated that almost all Jesuits would teach and that Jesuits would alternate learning, teaching, and other duties in ways that ensured a steady supply of well-educated teachers. The Jesuits then developed a school foundation model. Practically every school was based on a contract between the Society and civil authorities: the Jesuits governed and taught in the school while the ruler or city provided the necessary funding. The basic Jesuit school was a day school in which the Jesuits taught for free all the boys who came and passed an entrance examination. Jesuit day schools were Jesuit-civic partnerships.

The Jesuits developed a tripartite curriculum codified in the Ratio studiorum of 1599 that served three different student constituencies. The lower school taught the Renaissance humanistic curriculum whose goal was to produce eloquent, virtuous, and Catholic future leaders of society, men who would act for the common good. Next came the upper school, whose lower part consisted of three years of Aristotelian philosophy. This was basically a tightly organized version of the bachelor of arts curriculum of northern European and Iberian Peninsula collegiate universities. It was also preparation for university study of law, medicine, and theology. The second part of the upper school consisted of four years of Scholastic theology for priesthood candidates and ordained clergymen. However, the most subscribed theology course was not part of the Scholastic theology program. It was lectures on cases of conscience for pastors and confessors wanting practical guidance on penitential issues.

Class enrollments in Jesuit schools had the shape of a pyramid. Class sizes shrank as the material became more difficult and as students acquired the degree of Latin facility they desired and left. In the humanities school, the lowest Latin grammar class had the most students, and rhetoric, the highest class, had the fewest. It was the same in the philosophy curriculum, while enrollments in the theology classes were consistently small. Jesuit teachers in the lower school taught effectively while managing large classes through a combination 
of tightly organized exercises, repetition, student assistance, and competitions. Good academic performance was praised and weak performance ridiculed. The Jesuits taught boys from all ranks of society; indeed, a large majority of students came from the middle and lower classes.

Although most Jesuit schools were day schools, the Jesuits in partnership with rulers and wealthy supporters also established boarding schools. These were schools in which boys and youths lived in supervised residences under the academic and spiritual direction of the Jesuits. A reason for boarding schools was that they provided a complete Catholic environment in lands riven by religious division. Boarders attended the Ratio studiorum Latin classes offered by the local Jesuit day school. They also received instruction in other subjects taught by non-Jesuits. In Germany, Austria, and eastern Europe, boarding schools sometimes had a mix of students: sons of nobles and other wealthy parents who paid fees lived alongside poor students and young seminarians who did not.

The best-known Jesuit boarding schools were those limited to students of proven noble birth. The young nobles attended Latin classes at the local Jesuit day school. In addition, the Jesuits hired laymen to teach, and sometimes taught themselves, vernacular languages, riding, fencing, designing fortifications, singing, dancing, and playing musical instruments. Parents paid large fees for room, board, the expanded curriculum, and the opportunity for their sons to live with other young nobles.

The Roman national colleges were Jesuit seminaries for youths and young men from a particular political, geographical, and linguistic area of Europe who came to Rome to live and study. After ordination as secular priests, they returned to their native lands to minister to the Catholic population or as missionaries to persecuted Catholics.

A detailed look at France provides an overview of Jesuit pre-university education in a major European state. The Jesuits began to found schools in France in 1558 , suffered setbacks in the 1590s, and enjoyed rapid growth in the first forty years of the seventeenth century. The Jesuits then broadened their educational ministry, but also saw enrollment decline and faced competition from other teaching orders in the eighteenth century. The attitude of the French monarchy toward the Jesuits always influenced the fortunes of Jesuit schools. Of course, the history of Jesuit pre-university education differed from country to country and language region to language region. Nevertheless, a similar arc of school foundations, the rise of competition, and the influence of civil governments were common features throughout Europe. 


\section{Part 2: Universities}

\section{1 \\ The First Jesuits and Universities}

Just as the Jesuits had not intended to become schoolmasters, neither had they expected to become university professors. Nevertheless, the first Jesuits were so much the products of universities that it was not surprising that they added university teaching to their ministries.

All of the original Jesuits were university educated. That made them the best-educated founders of a religious order to that date in history. Although some of the first Jesuits began their university studies outside of Paris, all ten studied at the University of Paris. Nadal and Polanco, next in importance only to Loyola in the early Society, also studied at the University of Paris. ${ }^{156}$ All the first Jesuits plus Nadal and Polanco possessed multiple degrees, usually bachelor of arts, licentiate of arts, and master of arts. In a century when the number of clergymen who studied in universities was extremely small, the Jesuits stood out. Moreover, the University of Paris left an indelible impression on them and their educational policies. Hence, it was almost inevitable that the Jesuits would seek to teach in existing universities and try to found new ones.

Two, and possibly a third, of the first Jesuits taught in the University of Rome before the papacy approved the Society. Pope Paul III was much impressed when he heard Laínez and Pierre Favre (1506-46) debate as he dined. So he appointed them to teach at the University of Rome beginning in November 1537. Laínez taught Scholastic theology and Favre taught positive theology with a focus on the Bible until the summer of 1539. And Alfonso Salmerón (1515-85) may have lectured at the University of Rome in the academic year $1539-40 .{ }^{157}$

But when the Society was approved in 1540, the Jesuits had no intention of teaching in universities. Ignatius and other first Jesuits initially believed that after completing the novitiate young Jesuits could be educated in universities, just as they had been. Hence, between 1540 and 1544 the Society established its first nine colleges and residences in Alcalá de Henares, Coimbra, Cologne, Lisbon, Leuven (Louvain), Padua, Paris, Rome, and Valencia, all university towns except Lisbon. But Loyola and other leaders of the Society found university instruction disappointing and inadequate for their purposes, and they were dismayed at what they perceived to be the immoral culture of Europe's

${ }_{156}$ For a summary of the university careers of the founding Jesuits plus Nadal and Polanco, see Grendler, Jesuits and Italian Universities, 13-29.

157 A single source states that Salmerón lectured and preached there. Grendler, Jesuits and Italian Universities, 29-30. 
universities. So, they looked for alternatives, a search that became acute when they began to teach in pre-university schools.

At the same time, larger historical forces were elevating the importance of universities in European life and learning. That remarkable explosion of innovation and learning called the European Renaissance produced many new universities. Europe had twenty-nine universities in 1400 and added another twenty-seven in the fifteenth century. Another twenty universities were founded between 1500 and $1625 .{ }^{158}$ The reasons were multiple. The Renaissance produced an outpouring of new knowledge that universities helped create; they then refined, expanded, and taught the new knowledge. The growth of knowledge was as important or more important a cause for university expansion as the often-cited utilitarian argument that universities grew in order to provide trained men to fill positions in expanding governmental bureaucracieswhich was also true. The religious division of Europe also fueled university expansion. Protestant princes and divines founded new universities in order to educate subjects and clergymen in the new creeds. Catholic princes and scholars founded new universities to counter universities lost to Protestantism, and they sought to revivify those that had emptied out during the years of religious strife.

Loyola took notice of universities when he drafted the Constitutions of the Society of Jesus, the rules and organizational plan of the Society. But he came to universities late. He began to write the Constitutions in 1547 and by 1551 had written the section on schools, but nothing about universities. He then asked fellow Jesuits to study the constitutions of four Spanish universities, and he sought copies of the constitutions of the universities of Paris, Louvain, Cologne, Bologna, and Padua. In late 1553 or early 1554, Ignatius drafted a short section on universities that became chapters 11-17 (paragraphs 440-509) of the final version of the Constitutions. ${ }^{159}$

Ignatius affirmed that the Jesuits might undertake the charge of universities that would teach and confer degrees on non-Jesuit students. These graduates would then "teach with authority elsewhere what they have learned well in these universities for the glory of God our Lord." He saw universities as an extension of the ministry of the schools; hence, universities would be very similar to Jesuit schools. The rector of the local Jesuit college would have complete authority over the university. That included the power to appoint all the

${ }_{15} 8$ For a very brief summary, see Paul F. Grendler, "Universities," in Encyclopedia of the Renaissance, ed. Paul F. Grendler, 6 vols. (New York: Charles Scribner's Sons, 1999), 6:189-9o, which inadvertently omits Douai and Fermo.

159 Grendler, Jesuits and Italian Universities, 62-67. 
lecturers and to name a Jesuit chancellor, who would organize studies and confer degrees. Or the rector might serve as the chancellor. ${ }^{160}$

A Jesuit university would teach the humanities, philosophy, mathematics, and theology. But no Jesuit or Jesuit university would teach civil law, canon law, or medicine, because these disciplines were "more remote from our Institute." (Institute meant both the founding documents of the Society and its ministries.) Ignatius did leave a tiny loophole for canon law: Jesuit professors of theology might include some aspects of canon law, such as decrees of popes and church councils, in their teaching of theology. But they were forbidden to teach canon law insofar as it "is directed towards trials in court."161 Since a major reason for studying canon law was to acquire the expertise to win disputes in court and elsewhere, this meant that Jesuits could not teach canon law, and that Jesuit universities would not include professorships of canon law. The Society adopted Loyola's Constitutions as the law of the Society in $155^{8}$.

Ignatius's university vision was cautious, incomplete, and restricted. He envisioned only Jesuit universities, that is, universities completely controlled by the Society. This was partly because he saw the primary role of Jesuit universities as educating Jesuits. It is also likely that his frustration with the attempt to establish a civic-Jesuit University of Messina contributed to his preference for Jesuit universities. As mentioned in "The First School: Goa, Gandía, or Messina?," both the Jesuits and the city council of Messina expected that the Jesuit school there would quickly become the nucleus of a civic-Jesuit university in which the Jesuits would teach the humanities, philosophy, and theology, while lay professors would teach law and medicine. But the city and the Society differed on governance, meaning how much control each would have over the university, and how much the city would pay the Jesuits for their teaching. Negotiations were at an impasse when Loyola wrote the section on universities in the Constitutions and were not resolved at his death in 1556 . After another forty years of intermittent and contentious negotiations, the city of Messina founded the University of Messina in 1597 without any Jesuit participation. ${ }^{162}$ It is understandable that Loyola did not see how a civil authority and the Jesuits could share teaching and governance in a university.

Laínez and subsequent superior generals in the sixteenth century did not have a clear vision of Jesuits and universities either. But they very much wanted Jesuits to become part of universities. Laínez was particularly eager to send Jesuits north to teach theology in universities in order to fortify Catholicism

160 Constitutions, 177-90, quote on 177 .

161 Constitutions, $179-80$, quotes on both pages.

162 Novarese, Istituzioni politiche; and Grendler, Jesuits and Italian Universities, 37-94. 
in lands threatened by Protestantism. As Polanco wrote on behalf of Laínez in 1557 , there is such a scarcity of learned Catholic professors of theology in Germany. Hence, there is no place where teaching theology can be more necessary, useful, and better serve our Lord. ${ }^{163}$ So Laínez and subsequent generals and provincial superiors declined or postponed founding schools in Italy in order to send Jesuits to teach in German universities whether or not they were ruled by Jesuits. They were more willing to try different kinds of university arrangements, including a limited role for the Jesuits. As will be seen, Jesuit university participation did not follow a single model.

Once the Jesuits decided to become university teachers, they had some advantages. The Jesuit curriculum was an intense and somewhat rigid version of the European-wide Latin humanities, philosophy, and theology curriculum taught by all Catholic universities. This facilitated the Society's move into university teaching, even though the Jesuits would not teach law or medicine. For princes seeking help for their floundering universities or seeking to found new ones, the Jesuits were obvious potential partners. They were well-prepared scholars and teachers. And they would cost less than a comparable number of lay professors or secular clergymen. The result was that from 1555 to 1773 the Jesuits were more involved in universities than any other religious order before or since.

\section{$2 \quad$ The Civic-Jesuit Collegiate University Model}

As will be seen, the Jesuits sought both to found new universities and to become teachers in existing universities. They had no master plan, but responded to invitations and circumstances. Although each Jesuit-university encounter was unique, models emerged. Even though local arrangements altered details, the models summarized the curricular and legal conditions that defined the Jesuit role in a university. The most common model was the civic-Jesuit collegiate university.

Collegiate universities were corporate institutions consisting of colleges and faculties, with colleges as the heart of the university. ${ }^{164}$ Colleges were teaching and residence institutions in which teachers and students lived, taught, and

\footnotetext{
163 Letter of Polanco to Joannes Covillon, Rome, 17 June 1557, in Epistolae et acta Patris Jacobi Lainii secundi praepositi generalis Societatis Jesu ex autographis vel originalibus exemplis potissimum deprompta a Patribus ejusdem Societatis edita, vol. 2, 1557, ed. Ephrem Astudillo (Madrid: Typis Gabrielis López del Horno, 1912), 271.

164 Although the taxonomy of Jesuit universities is my own, the comments about collegiate universities of Willem Frijhoff, "Patterns," in A History of the University of Europe, vol. 2, Universities in Early Modern Europe (1500-180o), ed. Hilde de Ridder-Symoens (Cambridge: Cambridge University Press, 1996), 64-69, are useful.
} 


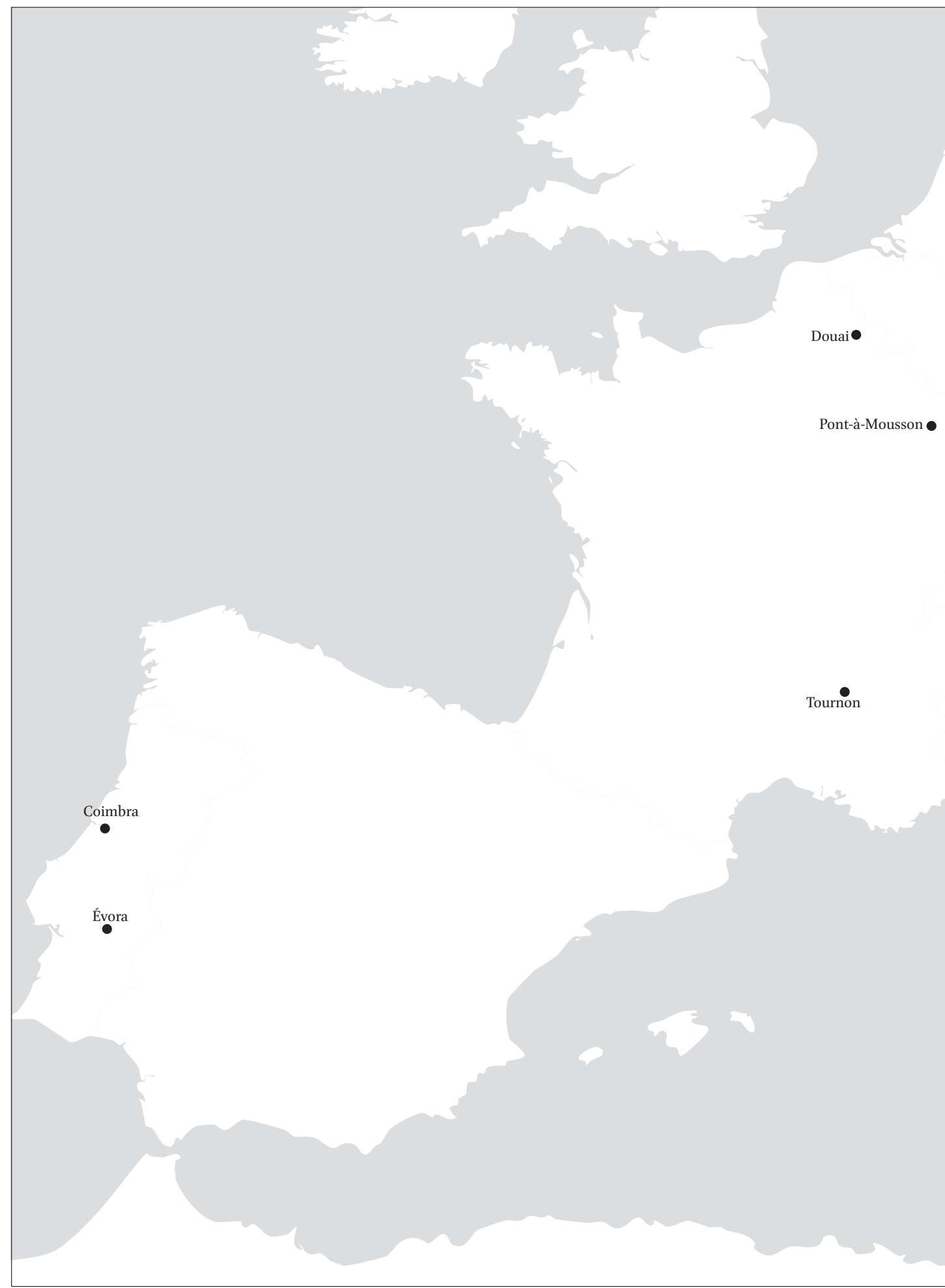

MAP 3

Civic-Jesuit universities and Jesuit universities mentioned in the text DOI: $10.6084 / \mathrm{mg}$.figshare.7301824 
Osnabrück

$\bullet$

Paderborn

Cologne

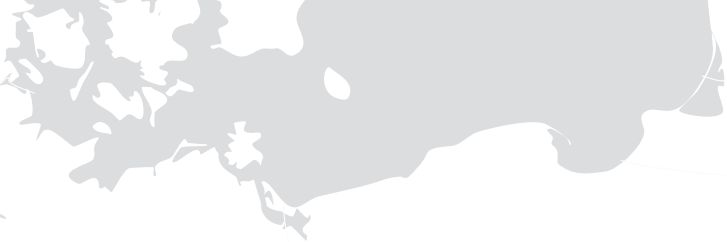

$\bullet$

Breslau (Wrocław)

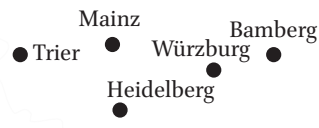

Prague

.

jusson $\bullet$

Heidelberg

Olomouc (Olmütz)

Strasbourg

- Molsheim

Dillingen Ingolstadt

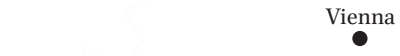

Innsbruck

Graz

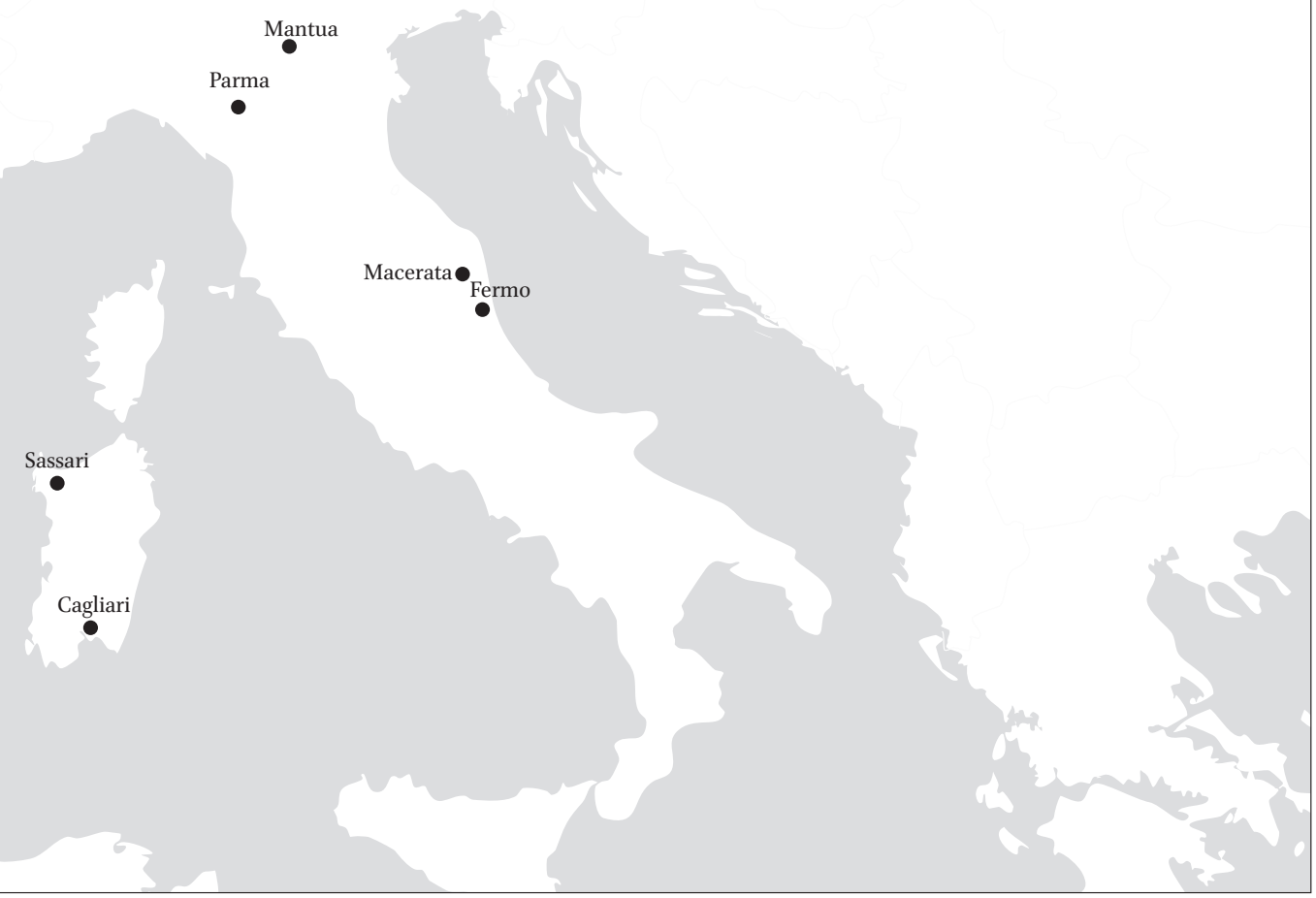


studied together. A collegiate university concentrated on teaching the humanities, philosophy, and theology. The vast majority of its students were young; they ranged in age from nine or ten to about twenty-one and lived in colleges. The students first learned or perfected their Latin by studying grammar and the ancient classics. The students then studied arts, which meant philosophy based on Aristotelian texts. For the vast majority of students, the bachelor of arts, licentiate of arts, or master of arts was the terminal degree. A small number went on to acquire degrees in theology, law, or medicine. Some theology students became regent masters. That is, they supported themselves by teaching the humanities and philosophy while studying theology. In the terminology of twenty-first-century North American and, to a lesser extent, European education, a collegiate university was a combined secondary school and undergraduate university topped off by theology, plus a little law and medicine. All northern European and Iberian Peninsula universities were collegiate universities.

Collegiate universities did not teach a great deal of law and medicine, which were faculties. A great imbalance between the number of teachers of arts and theology, whether regent masters or professors, and professors of law and medicine, characterized collegiate universities. The University of Paris, a collegiate university on a grand scale, had at least forty secular colleges, several hundred regent masters and professors of arts and theology, and an estimated twelve thousand to twenty thousand students in the sixteenth century. ${ }^{165}$ But Paris had only a few professors of medicine and canon law and did not teach civil law. The University of Vienna, a modified collegiate university, had sixteen professors of arts and theology, plus regent masters, but only four professors of law and three of medicine in $1554 \cdot{ }^{166}$

Collegiate universities were clerical and religious in culture because the overwhelming majority of teachers were clergymen or would-be clergymen, and because the colleges in which the vast majority of students and teachers lived, taught, and studied had quasi-monastic rules. In small collegiate universities, a single college might dominate the university, and sometimes a religious order ruled and taught in the dominant college.

A civic-Jesuit collegiate university was a collegiate university in which the civil power and the Society shared governance. The civil ruler-most often the

165 James K. Farge, "Paris, University of," in Encyclopedia of the Renaissance, 4:404.

166 Joseph S. Freedman, "Philosophy Instruction within the Institutional Framework of Central European Schools and Universities during the Reformation Era," History of Universities 5 (1985): 132-34. 
king or prince - gave the Society an important position in a collegiate university, almost always to teach philosophy and the humanities, often theology as well. The Society became part of the corporate structure of the university. That is, the statutes of the university codified the local college of the Society as a part of the university with certain privileges, rights, and responsibilities. A contract between the university or the civil ruler and the Society indicated that the Jesuits were to be paid a specified amount for their teaching in the university. University statutes and rules indicated which teaching positions Jesuits would fill and their obligations. The contract and statutes commonly stipulated that Jesuit superiors, not the university or the civil ruler, would choose the Jesuits who would fill the contracted teaching positions. In civic-Jesuit collegiate universities, the Society typically dominated the arts through its college and school, or arts and theology, but had little or no influence in the rest of the university.

\section{$3 \quad$ The University of Coimbra}

The initial participation of the Jesuits as teachers in a European university was at Coimbra where the Society obtained a strong institutional position in an existing university. The Coimbra experience established a civic-Jesuit collegiate university model replicated elsewhere.

King John III Aviz of Portugal (1502-57, r.1521-57) decided to improve the University of Coimbra. Founded in Lisbon in 1290, the university had a transient existence until the king moved it to Coimbra in 1537 where it stayed. He then set about improving it. Not happy with the instruction and teachers, in February 1548 he founded the Colégio das Artes (also called Royal College of Arts) to teach the humanities and philosophy. The College of Arts was a combination teaching and residential college in which teachers and fee-paying students lived, taught, and learned under one roof. It imitated the Collège de Sainte-Barbe in Paris, where five to seven first Jesuits, including Ignatius of Loyola, had lived and studied between 1528 and 1536 . The king gave the Colégio das Artes a prominent position in the university and invited a Portuguese academic administrator who had served as principal of the Collège de Sainte-Barbe to be its principal. To staff his new college, the king persuaded some prominent non-Portuguese academics from the University of Paris and a prominent school in Bordeaux, where Michel de Montaigne (1533-92) had studied, to move to the College of Arts of Coimbra. The teachers at the College of Arts did the greater part of the university's teaching in Latin grammar, rhetoric, poetry, Greek, Hebrew, mathematics, and philosophy. Equally important, no student was admitted into the upper faculties of theology, canon law, 
civil law, and medicine without a certificate from the principal of the College of Arts attesting that he had studied philosophy in the college. ${ }^{167}$

Despite all this, the College of Arts did not flourish. The principal suddenly died in June 1549, and his successors failed to quell turmoil among the teachers, who split into Paris, Bordeaux, and Portuguese factions. Worse, the Portuguese Inquisition tried some teachers for heresy; they abjured minor heretical beliefs and fled Portugal. And low student enrollments produced a financial shortfall. So the king turned to the Jesuits. In 1542, the Jesuits had established a non-teaching College of Jesus in Coimbra for young Jesuits attending classes in the university, and it began to teach in $155^{2}$. In 1555 , John III, who highly esteemed the Jesuits, asked them to take charge of the Colégio das Artes. He also realized that the annual payment that the university would give the Society for its teaching would be less than the cost of hiring an equal number of non-Jesuits. Ignatius accepted the king's offer. Not only was this an opportunity to teach in a university, but the appeal of recreating for others the student experience of the first Jesuits in the Collège Sainte-Barbe in Paris must have been irresistible. Ignatius and Laínez dispatched some of the Society's most talented scholars, including Manoel Alvares (1526-83), Cipriano Soares, and Pedro da Fonseca to teach in the College of Arts. ${ }^{168}$

A Jesuit became principal of the College of Arts, and the Jesuits became a major constituent part of the University of Coimbra. The Jesuits taught and lived with most of the students studying humanities and philosophy in pursuit of bachelor, licentiate, and master of arts degrees. The Jesuit principal

167 Mário Brandão and M. Lopes D’Almeida, A Universidade de Coimbra: Esboço da sua história (Coimbra: Por ordem da Universidade, 1937), part 1:181-213; and António de Vasconcelos, Os Colégios universitários de Coimbra (Coimbra: Coimbra Editora, 1938), 1-77. Theophilo Braga, História da Universidade de Coimbra nas suas relações com a instrucção publica portugueza, 2 vols. (Lisbon: Typographia da Academia Real das Ciencias, 1892-95), argues that the Jesuits schemed to enter the university, for which evidence is lacking, and that their entry initiated the decay of the university. Given the modest state of the university before 1555, the second statement is laughable. See also Cándido María Ajo González de Rapariegos and Sáinz de Zúñiga, Historia de las Universidades hispánicas, vol. 2, El siglo de oro universitario (Ávila: Senén, 1958), 276-91; Cristiano Casalini, Aristotle in Coimbra: The Cursus Conimbricensis and the Education at the College of Arts, trans. Luana Salvarani (Abingdon: Routledge, 2017), 21-24.

168 Rodrigues, História, vol. 1, part 2:336-73; Brandão and D’Almeida, A Universidade de Coimbra, part 1:203-8; Dauril Alden, The Making of an Enterprise: The Society of Jesus in Portugal, Its Empire, and Beyond 1540-1750 (Stanford, CA: Stanford University Press, 1996), 30-32; Casalini, Aristotle in Coimbra, 34-35, 37-41; Liam Matthew Brockey, The Visitor: André Palmeiro and the Jesuits in Asia (Cambridge, MA: Harvard University Press, 2014), 33-74, provides a good survey of the Jesuits in the University of Coimbra by focusing on one Jesuit there. 
determined which might advance to the higher faculties of law, medicine, and theology. ${ }^{169}$ The results were impressive. Student enrollment in the College of Arts and the number of Jesuits in the university soared. In the 1570s, the College of Arts had 1,500 students, and there were 160 to 175 Jesuits in the two Jesuit colleges at Coimbra. In the late sixteenth century, the Jesuits in the College of Arts offered sixteen classes, including five in theology, which were attended by nearly two thousand students ranging in age from about ten to adults, while the College of Jesus taught additional students. Although the College of Jesus and the College of Arts were legally distinct, a large new building was erected at university expense to house both in the early seventeenth century. ${ }^{170}$ On the other hand, the Jesuits did not rule other teaching colleges, or the faculties of theology, law, and medicine.

The Coimbra Jesuits made a major contribution to European philosophy instruction through the Cursus Conimbricensis (Coimbran course, but usually called the Coimbra Commentaries). It was a comprehensive course of Aristotelian philosophy prepared by the Jesuits at Coimbra under the supervision of Fonseca. It consisted of eight books published between 1592 and 1606 covering all the works of Aristotle except the Metaphysics. Each volume dealt with an Aristotelian work, or several short works, by presenting the Greek text (with one exception), a Latin translation on the same page, a paraphrase explanation of the text, and then quaestiones, that is, discussions of major points of the text. The quaestiones material, usually longer than the original text, raised questions and presented responses offered by ancient Greek commentators, medieval Scholastics, Renaissance humanists, and recent scholars. It was a condensed history of scholarship on major issues in Aristotle. Teachers in Catholic and Protestant Europe used the Cursus Conimbricensis through the middle of the seventeenth century. ${ }^{171}$

However, the Jesuit presence generated friction with other parts of the university. When John III moved the university to Coimbra in 1537, he awarded it

169 Alden, Making of an Enterprise, 32n29, reports that there is no evidence that the Jesuits used this power to exclude qualified applicants from the higher faculties.

170 Rodrigues, História, vol. 1, part 2:374-400; vol. 2, part 2:15; Sáinz y Zúñiga, Historia de las universidades hispánicas, vol. 3, Periodo de los pequeños Austrias (Madrid: Artes Gráficas C. I. M., 1958), 207-17; Casalini, Aristotle in Coimbra, 34-35, 37-41; Brockey, Visitor, 63, 68; and Nuno da Silva Gonçalves, S.J., "Jesuits in Portugal," in Mercurian Project, 729, 739 .

171 A useful study is Cristiano Casalini, Aristotele a Coimbra: Il Cursus Conimbricensis $e$ l'educazione nel Collegium Artium (Rome: Anicia, 2012); and its English translation Aristotle in Coimbra. For a brief translated excerpt of the volume on the Nicomachean Ethics, see Cambridge Translations of Renaissance Philosophical Texts, vol. 1, Moral Philosophy, ed. Jill Kraye (Cambridge: Cambridge University Press, 1997), 80-87. 
funds and properties whose income was designed to cover almost all university expenses. Hence, the payments to the Jesuits for their teaching in the College of Arts came from the university treasury, not from a separate endowment. As the College of Arts enrollment increased, the Jesuits asked for more money and a larger building. Other sectors of the university opposed their requests. ${ }^{172}$

Second, the Jesuits asked for university rights that they maintained came from their position in the College of Arts or were needed to carry out their responsibilities. For example, the Coimbra Jesuits asked that any Jesuit teacher, for example, one coming to the College of Arts from another Jesuit school in Portugal, be regarded as having received an education equivalent to that of Coimbra. Hence, he should be deemed a full member of the university without paying fees, and he should be awarded various privileges including the right to examine degree candidates. This mattered, because many Portuguese Jesuits lacked degrees, and because universities tended to restrict privileges to their own graduates. Other sectors of the university objected. Members of the Portuguese royal family called on to resolve such disputes generally favored the Jesuits, which did not quell resentments. ${ }^{173}$

Another source of friction came from the exclusion of the Jesuits from the faculty of theology of the University of Coimbra. The Dominicans, Franciscan Conventuals, Augustinian Hermits, and other religious orders had residence-and-teaching colleges in Coimbra that were constituent parts of the university. Members of these orders filled all of the university professorships of theology and scripture at the university. ${ }^{174}$ Although the Jesuits taught theology in the College of Arts and in the College of Jesus, they were not university theologians. Hence, they could not examine theology degree candidates, and they lacked other university rights and privileges.

A proposed appointment focused attention on their exclusion. In 1597, Philip II (1527-98, king of Spain 1556-98, king of Portugal 1581-98), decided that the University of Coimbra should appoint to its first position professorship of theology, the most important in the university, the Spanish Jesuit

172 Rodrigues, História, vol. 2, part 1:139-64; Brandão and D'Almeida, A Universidade de Coimbra, part 1:196-97, 216-21; Vasconcelos, Os colégios de Coimbra, 42-46; Brockey, Visitor, 36-37; Casalini, Aristotle in Coimbra, 40.

173 Rodrigues, História, vol. 1, part 1:585-93; Brandão and D’Almeida, A Universidade de Coimbra, part 2:12-13, 18-19; Alden, Making of an Enterprise, 31-32; Casalini, Aristotle in Coimbra, 40.

174 Exactly how many university professorships of theology and scripture there were is hard to determine. Friedrich Stegmüller, Filosofia e teologia nas Universidades de Coimbra e Évora no século XVI (Coimbra: Universidade de Coimbra, 1959), 12, puts the number as four major (three theology and one scripture) plus four minor (three theology and one scripture) professorships, in 1597, and lists their occupants. 
Francisco Suárez. ${ }^{175}$ Suárez was undoubtedly the most distinguished living Catholic theologian in Europe. But a Portuguese Augustinian Hermit, who held the second theology position, objected because Suárez lacked a doctorate. He probably spoke for other university theologians as well, because a doctorate was the normal prerequisite for joining a faculty of theology across Europe. They may also have opposed Suárez because he was a Spaniard, as many Portuguese disliked the dynastic union. So, Suárez made a brief visit to the Jesuit University of Évora, participated in a public disputation, probably the Jesuit "General Acts" (see the next section), and was awarded a doctorate of theology. He then assumed the Coimbra professorship. ${ }^{176}$ But it does not appear that any other Jesuits were appointed university theologians.

Thus the Jesuits entered the University of Coimbra. They did not join the university as individual teachers. Instead, the Society was given a key institutional position, stronger than that of any other religious order by far, in an existing university. They dominated instruction in the humanities and philosophy and determined who might enter the advanced faculties. They attracted many students and taught them well. But they did not rule the entire university, and their presence generated resentment.

\section{$4 \quad$ The Jesuits and University Degrees}

The story of Suárez raises a question: Why did he lack a doctorate of theology? Although he had been teaching philosophy and theology for many years, so far as can be determined he had no degrees at all. Neither did Bellarmine and many other distinguished Jesuit scholars. The answer is complex and bound up with the larger issue of the authority of Jesuit schools and universities to confer degrees. And Jesuit policy evolved.

The inconsistencies of the Jesuit policy on degrees originated with Ignatius of Loyola. Noticeably absent from the section on universities in the Constitutions was discussion about the procedures for conferring degrees. Indeed, Ignatius seemed unenthusiastic about Jesuits obtaining degrees. He stated that candidates for degrees should be examined carefully. He then immediately warned against treating Jesuit degree-holders with too much deference:

\footnotetext{
175 When the last member of the Aviz family died, Philip II of Spain became the king of Portugal as well, thanks to marriages between the two royal families. It was a dynastic union only, as the two kingdoms were not unified. Portugal retained its own administration and laws subject to the approval of the Council of Portugal in Madrid and the Spanish king. The Portuguese strongly objected to the dynastic union and threw it off by force in 1640 .

176 Rodrigues, História, vol. 2, part 2:177-88; Brandão and D’Almeida, Universidade de Coimbra, part 2;20-23; Eleuterio Elorduy, "Suárez, Francisco," DHCJ, 4:3655; and Brockey, Visitor, 59-6o.
} 
no Jesuit should be honored above his fellows because he had a degree. Ignatius then wrote that degrees should be free, and that no Jesuit or Jesuit college should accept money or gifts for their roles in conferring degrees. He finished by forbidding banquets "and other celebrations which are costly and not useful [...]. Neither should there be any conferring of caps or gloves or any other object." ${ }^{\prime 77}$ What he criticized was practically obligatory across Europe after a degree was awarded. It is likely that Ignatius remembered his experiences at Paris. While he won bachelor of arts, licentiate of arts, and master of arts degrees there, he postponed receiving the master of arts degree for nearly two years while he begged the funds to pay its expenses. Favre, another first Jesuit at Paris, did the same. ${ }^{178}$

Then there was the issue of requirements for degrees, especially the doctorate of theology. University statutes prescribed years of attendance at lectures, disputations, and other hurdles to be surmounted before a candidate might sit the examination for the doctorate. The Jesuits disagreed; the Society's decision that four years of theological study was enough was a rejection of the dozen or more years of study required of candidates for doctorates of theology at the University of Paris and elsewhere. But there was a drastic short cut: a candidate could simply pass an examination before an individual empowered to confer doctorates and receive the doctorate. This path was readily available, because every university town in Europe had professors, clergymen, and laymen, sometimes with no connection to the local university, who had been granted the power from pope or emperor or had inherited it from an ancestor. Consequently, many men sought and obtained doctorates by examination. The degrees were sometimes derisively called doctorates per saltum (by leap), because the candidate leaped over the requirements in order to obtain the degree by examination. Or they were called doctorates per bullam, because the doctorate was received from an individual possessing a papal bull or imperial document empowering him to award doctorates. Naturally, the person examining a candidate received a fee. But it was far less than the cost of a doctorate from a university in which many men received fees and gifts. ${ }^{179}$

Loyola and other first Jesuits took advantage of the doctorate per saltum route for what they saw as a greater good. In 1549, Wilhelm IV Wittelsbach, duke of Bavaria (1493-1550, r.1508-50), wanted some Jesuits to teach theology at the University of Ingolstadt. Ignatius agreed to send Claude Jay (c.1504-52),

177 Constitutions, paragraphs 390, 478-80, pp. 164, 185 (quote).

178 Grendler, Jesuits and Italian Universities, 18-19.

179 Paul F. Grendler, The Universities of the Italian Renaissance (Baltimore: Johns Hopkins University Press, 2002), 180-86. 
Salmerón, and Canisius. Ignatius knew that professors of theology were expected to possess doctorates of theology, which the three Jesuits lacked. So, he arranged for them to obtain doctorates by being examined by three Dominicans in Bologna who were members of the Faculty of Theology of the University of Bologna, which had the power to confer doctorates of theology. This was the case even though the University of Bologna did not teach theology at this time. Jay, Salmerón, and Canisius went to Bologna, spent a few days there, passed the examination, were awarded doctorates, and immediately left for Ingolstadt. ${ }^{180}$ Salmerón and Canisius were learned men who had attended theology lectures, the first two at Paris and Canisius at the University of Cologne. But they had not satisfied the numerous and lengthy requirements for the doctorate of theology from the Faculty of Theology of the University of Bologna.

A number of other Jesuits also obtained doctorates by examination in the $1550 \mathrm{~s}$ and $1560 \mathrm{~s}$, almost always so that they might teach theology in northern Europe. And when in $155^{2}, 1556$, and 1561 popes conferred on all Jesuit schools the right of awarding degrees in theology and philosophy after a rigorous examination, the Roman College and a handful of Jesuit universities in northern Europe conferred doctorates of theology on some Jesuits. ${ }^{181}$

But then the Jesuits stopped obtaining doctorates by examination. Superior General Mercurian wrote that degrees should be conferred on Jesuits very rarely, and other Jesuits agreed. ${ }^{182}$ A reason was anger and criticism from universities, who asserted that only they had the right to confer degrees. Of course, they also wished to protect the fees and gifts that professors who participated in degree examinations received. The Roman College continued to confer doctorates on non-Jesuit clergymen, especially future cardinals, but stopped awarding degrees to Jesuits. ${ }^{183}$ Other Jesuit schools also stopped awarding degrees, or they awarded fewer of them in the 1570s, 1580s, and 1590 .

The Ratio studiorum of 1599 forged a compromise. After four years of theological studies, both Jesuit and non-Jesuit students might engage in Special Acts (actus peculiares) or General Acts (actus generales). These were formal disputations covering all of theology; Special Acts lasted two-and-one-half hours and General Acts four or five hours. But they were not degrees. It then added: "Where it is the local custom, some of these [students who participated in Acts] can be promoted to the rank of doctor or master with the permission

180 Grendler, Jesuits and Italian Universities, $428-30$.

181 Grendler, Jesuits and Italian Universities, 430-33.

182 Grendler, Jesuits and Italian Universities, 434-39.

183 Villoslada, Collegio Romano, 269-72; and Grendler, Jesuits and Italian Universities, 339-40. 
of the general."184 The effect was to discourage awarding degrees but permitting it when customary or necessary.

By about 1600 , a satisfactory alternative arrangement was in place. The Jesuits had joined a number of collegiate universities or had founded Jesuit universities in partnership with rulers, almost always in northern Europe and the Iberian Peninsula (see below). These universities awarded many bachelor of arts, licentiate of arts, and master of arts degrees, and a lesser number of doctorates of theology and philosophy. They awarded the degrees on the basis of university charters obtained by civil rulers from pope or emperor that empowered the university of (name) to confer degrees with the usual ceremonies, powers, and privileges. Hence, the university, rather than the Jesuit school, conferred the degree. This was true whether the Jesuits ruled the entire university (see "Jesuit Universities" below), or was a significant component of the university as at Coimbra, or a small part. The arrangement had several advantages. It preserved the traditional powers and practices of university charters. It deflected criticism that the Jesuits were usurping the right of universities to award degrees. It ensured that non-Jesuit professors would continue to receive compensation for their participation in degree examinations and ceremonies. At the same time, Jesuit schools, whether part of a university or not, retained their power based on papal bulls to confer degrees on their own authority. Which was what they did for Suárez.

\section{$5 \quad$ The Jesuits in Central European Universities}

The Coimbra story was repeated in central Europe where the Jesuits also became part of universities. Civic-Jesuit collegiate universities in central Europe included Cologne, Heidelberg from 1629, Ingolstadt, Innsbruck, Mainz, Prague, Trier, Würzburg, and Vienna. ${ }^{185}$

Cologne, a collegiate university founded in 1388 , offers an example. By the middle of the sixteenth century, enrollment was very low, and there were only three arts colleges left, one of which the city ruled. Then in 1556 the city transferred its college, the Tricoronatum (College of the Three Crowns), to the mayor's son, who had joined the Jesuits, and then to the Society. Bolstered by some able Jesuit teachers, it did well. From the 1570 s onward, the Tricoronatum

\footnotetext{
184 Ratio studiorum, paragraphs $16-17,105^{-13}$, quote on p. 11.

185 Although my analysis and terminology is not exactly the same, some of what follows has been influenced by Rainer A. Müller, "Universitas et Societas Jesu': The Catholic Universities in Early Modern Germany," in Università in Europa: Le istituzioni universitarie del Medio Evo ai nostri giorni; Strutture, organizzazione, funzionamento, Atti del Convegno Internazionale di Studi. Milazzo 28 settembre-2 ottobre 1993, a cura di Antonella Romano (Messina: Rubbettino Editore, 1995), 395-403.
} 
College enrolled as many students as the other two colleges combined, including prominent future scholars and important citizens of Cologne. On the other hand, the Jesuits did not dominate theology. They were awarded only two of the twenty-four professorships, while the rest were filled by medieval order friars and members of the secular clergy. ${ }^{186}$

Other German universities did the same, because they had suffered devastating declines in enrollment, faculty flight, and loss of prestige during the years of religious strife. The prince-archbishop of Trier judged that the University of Trier, founded in 1473, was nearly moribund. So he invited the Jesuits into the university and provided financial support. The Jesuit college and its school became one of the two colleges comprising the university, and the Jesuits began to teach in the university in February 1561. The rector of the university, a clergyman, was not happy at the addition of the Jesuits, but could do nothing about it. The Jesuits taught the humanities and dominated philosophy and theology. ${ }^{187}$ The University of Mainz (founded in 1477) was also devastated by war, low enrollments, and lack of scholarly achievement. So the local archbishop invited the Jesuits to come and revive it. He provided funds for the Jesuits to open a school in 1561 and gave them two residences owned by the faculty of arts. The Jesuits dominated the teaching of philosophy and theology. 188

Winning a major position in a university might take decades of struggle. As described above, the duke of Bavaria welcomed three Jesuit theologians into the small University of Ingolstadt in 1549. But the Jesuits did not establish a college and the three Jesuits left in 1552 . The Society returned to establish a

186 See Duhr, Geschichte, 1:33-45, and vol. 2, part 1:582-86; Erich Meuthen, Die alte Universität, Kölner Universitätsgeschichte Bd. 1 (Cologne: Böhlau, 1988), 298-305 and passim. See also Meuthen, "A Brief History of the University of Cologne," a ten thousand-word English summary of his book, at www.portal.uni-koeln.de/universitaetsgeschichte.html?\&L=1 (accessed July 4, 2018). See also Siegfried Schmidt, "Das Gymnasium Tricoronatum unter der Regentschaft der Kölner Jesuiten," in Die Anfänge der Gesellschaft Jesu und das erste Jesuitenkolleg in Köln (Cologne: Erzbischöfliche Diözesan- und Dombibliothek, 2006), 71-186.

187 Duhr, Geschichte, 1:95-100; Karl Hengst, Jesuiten an Universitäten und Jesuituniversitäten (Paderborn: Ferdinand Schöningh, 1981), 110-16; Markus Pillat, "The Jesuits in the Rhineland Province," in Mercurian Project, 90-93; and Grendler, Jesuits and Italian Universities, 431-32 and note 54 .

188 Duhr, Geschichte, 1:103-9; Hengst, Jesuiten an Universitäten, 116-27; Pillat, "The Jesuits in the Rhineland Province," 93-94; and Rolf Decot, "Anfänge der Jesuiten in Mainz und ihre historische Forschung zum Erzstift," in Konfessionskonflikt, Kirchenstruktur, Kulturwandel: Die Jesuiten im Reich nach 1556, herausgegeben von Rolf Decot (Mainz: Verlag Philipp von Zabern, 2007), 41-65. 
college in 1556. After a bitter struggle, the Jesuits won two theology professorships and complete control of the teaching of philosophy by 1588.189

The Jesuits were originally brought to Vienna in order to counter Protestantism, but eventually became a key part of the University of Vienna. Ferdinand I Habsburg (1503-64, king of Bohemia and Hungary 1526-64, Holy Roman emperor 1558-64) noticed that some professors and students were Protestants. So he invited the Jesuits to come to Vienna, a move that Ignatius of Loyola enthusiastically endorsed. The Jesuits arrived in 1551, established a college with the financial assistance of Ferdinand I, and began to teach. Ferdinand I then established a university reform commission, whose membership included Canisius, to write a new constitution for the university. Promulgated in 1554, it reduced the powers of the corporate units of the university and somewhat reorganized the university. It expanded the emperor's influence, but did not give him absolute power over the university. In the next half century, the Jesuit school taught philosophy and theology alongside but not in the university. The university strenuously objected but, unlike the University of Paris (see "Universities Warring against Jesuit Schools" below), could not exclude from the university students who attended Jesuit classes. The university added regulations that made it more Catholic, while respect for the free instruction of the Jesuits grew. Hence, in 1623 Holy Roman Emperor Ferdinand II Habsburg (1578-1637, r.1619-37) incorporated the Jesuits into the university, giving them all of the professorships of philosophy and most of the professorships of theology. But the Jesuits never governed the university. No Jesuit might become rector of the university, and the Jesuits had no authority over the faculties of law and medicine. ${ }^{190}$

The story of the Jesuits and the Charles University of Prague was similar. Founded in 1348, it was Hussite and Protestant. Then the Jesuits with the strong support of the Habsburg monarchy established the college and school of St. Clement in Prague in 1556. After much conflict between the Charles University and the Jesuit school, Ferdinand II united the faculties of laws and medicine of the Charles University with the teaching of philosophy and theology of

189 Duhr, Geschichte, 1:53-65; and vol. 2, part 1:558-67; James Broderick, Saint Peter Canisius (Chicago: Loyola Press, 1998), 131-67; Hengst, Jesuiten an Universitäten, 86-95; Haub, "From Peter to Paul," 156-58; and Susan Spruell Mobley, "The Jesuits at the University of Ingolstadt," in Mercurian Project, 213-48.

190 Duhr, Geschichte, 1:45-53; and vol. 2, part 1:541-53. For a succinct English summary of the Jesuits in Vienna, see Gernot Heiss, "Educational Politics in the Austrian Lands and the Foundation of the Jesuit University of Graz, 1585," in European Universities in the Age of Reformation and Counter Reformation, ed. Helga Robinson-Hammerstein (Dublin: Four Courts Press, 1998), 171-76. 
the Jesuit St. Clement school in 1622, to create the Charles-Ferdinand University. This did not succeed immediately because the Jesuits were twice driven out of Prague during the Thirty Years' War. Holy Roman Emperor Ferdinand III $(1608-57$, r.1637-57) renewed the union in 1654, and this time it succeeded. The rectorship of the university rotated among the faculties. ${ }^{191}$

Sometimes, the Jesuits joined a university after a Catholic military conquest. The University of Heidelberg, founded in 1386, became Calvinist in 1559, Lutheran in 1576, returned to Calvinism in 1583 , but closed when Catholic forces captured the city in the Thirty Years' War. It reopened as a Catholic university in 1629 , at which time the Jesuits were introduced into the university. Despite more closures and attempts to return the university to Protestantism, they remained until the suppression. ${ }^{192}$

\section{$6 \quad$ Italian Civic-Jesuit Universities}

The Jesuits succeeded in entering a few Italian universities even though they were profoundly different from collegiate universities.

Italian universities were law-and-medicine doctoral universities, the approximate equivalent of twenty-first-century professional schools. ${ }^{193}$ They conferred only doctorates; bachelor and master's degrees had disappeared by 1450 because students saw them as an unnecessary expense. Italian universities awarded degrees only in law, medicine, and theology, not in arts. Sixty-seven to seventy-five percent of the doctorates awarded in the sixteenth century were in law and medicine, and the percentage of law doctorates rose in the next two centuries. Civil law dominated; canon law was an appendage. Italian universities did teach philosophy, but it was considered preparation for the study of law and medicine. They offered little humanities and theology instruction.

Students in Italian universities were older than those in collegiate universities. Italian students acquired expertise in Latin in humanistic pre-university schools before going to a university. They came at the ages of seventeen or eighteen and stayed until the ages of twenty-four or twenty-five. Because Italian universities were Europe's leaders in law and medicine, many northern Europeans and Spaniards acquired bachelor or master of arts degrees at home, then went to Italy for doctorates in law or medicine. This also raised the average student age. Students in Italian universities were laymen, with the exception of the small number of clergymen who studied theology. Students

\footnotetext{
191 Josef Koláĉek, “Colegio San Clemente de Praga," DHCJ, 1:852-53.

192 Duhr, Geschichte, vol. 2, part 1:178-82.

193 This and the succeeding paragraph are based on Grendler, Universities; and Grendler, Jesuits and Italian Universities, 46-51.
} 
lived in unsupervised rented quarters; Italian universities lacked teaching-andresidence colleges with semi-monastic rules. The student culture was lay and quarrelsome; most students carried swords, and townspeople hid their daughters. Professors were almost exclusively laymen except for the one or two friars from local monasteries who taught theology. About seventy-five percent of the professors taught law or medicine; the rest taught theology, philosophy, and the humanities. Finally, Italian universities were civic. City councils and princes chose the professors and paid the bills. Given the differences, the Jesuits faced formidable obstacles if they wished to teach in Italian universities. Nevertheless, two Italian princes and two city councils gave them roles in new universities.

The ruling dynasty and the city of Parma in northern Italy had wanted a university for a long time. Duke Ranuccio I Farnese of the duchy of Parma and Piacenza decided to found a university, and he invited the Jesuits to be part of it. After extensive negotiations, the Society agreed to provide a certain number of teachers for specified positions for which they would receive payment. The Society would choose which Jesuits would teach in the university. The duke and the city of Parma would appoint and pay the professors of law and medicine. The University of Parma began to teach in the autumn of $1601 .{ }^{194}$

The University of Parma was a middle-sized Italian university of twentyseven to thirty professors (there were no regent masters), nine of them Jesuits, one-third of the total. Two Jesuits taught Scholastic theology, and single Jesuits taught moral theology, metaphysics, natural philosophy, logic, mathematics, moral philosophy, and rhetoric. In the eighteenth century, the Jesuit professorship of moral philosophy became scripture. Unlike collegiate universities, the rest of the Jesuit establishment in Parma, which included the college, lower school, and a noble boarding school, was not part of the University of Parma. ${ }^{195}$

A closer look reveals that the Jesuit teaching positions did not conform completely with Italian university practice. All medium- to large-sized Italian universities had concurrents, that is, two or more professors who taught the same subject and text at the same hour. Proponents believed that this gave students choices and that competition stimulated better teaching. It also produced bitter rivalries between concurrents and among students who followed one or the other. For the Jesuits, concurrents would have meant a layman teaching a different analysis of Aristotle's Physics in natural philosophy, and a Franciscan teaching Scotist theology in competition with a Jesuit teaching Thomism. Although the University of Parma had concurrents for all the major positions in

194 Grendler, Universities, 129-32; and Grendler, Jesuits and Italian Universities, 154-61.

195 Grendler, Jesuits and Italian Universities, 164-69, 174-75. 
civil law, canon law, and medicine, the Jesuits refused to accept concurrents for any of their positions. This was consistent with their goal of teaching a consistent and thorough understanding of a discipline. They believed that presenting philosophical and theological differences confused students and allowed errors to creep in. The duke acquiesced. ${ }^{196}$ In the negotiations, the Jesuits also asked to teach their university classes in their own school at some distance from where the law and medicine lectures would be held, arguing that this would produce greater quiet and discipline for their students. Again, their request was granted; the law and medicine professors taught in a renovated palace located a fifteen-minute walk distant from the Jesuit school. ${ }^{197}$

Additional curricular and pedagogical details reveal more about how the Jesuits fitted into an Italian law and medicine university while remaining faithful to the Ratio studiorum. Although the Jesuits comprised about one-third of the professors, they offered about forty percent of the lectures, because the four Jesuits who taught metaphysics, natural philosophy, logic, and rhetoric lectured twice daily, in the morning and the afternoon. They did so because the Ratio studiorum mandated it. By contrast, Italian university professors almost never delivered two daily lectures in the same discipline, and very few held two positions. The Jesuit professors of Scholastic theology, moral theology, and mathematics lectured only once daily, again because the Ratio studiorum decreed it. In short, when the Ratio studiorum and university practice differed, the Jesuits at Parma followed the Ratio studiorum.

Around 1660, the Parma Jesuits sought permission from the reigning duke to modify the length of their lectures in order to follow the Ratio studiorum more closely. Italian university lectures began on the hour and lasted an hour. Up to this date, the Parma Jesuits had done the same. Now they wished to present an hour-long lecture followed by a half-hour of review, which was what the Ratio studiorum recommended. ${ }^{198}$ At the same time, the Jesuits sought to avoid schedule conflicts with, and ill-will from, professors and students of law and medicine. So a compromise was reached. The Jesuits were given ninety minutes to teach at the last morning teaching hour (which might stretch into the lunch break) and the last two teaching hours in the afternoon, which were considered less desirable times to lecture. ${ }^{199}$ By contrast, the professors of law and medicine lectured for one hour in the early morning or the early afternoon.

\footnotetext{
196 Grendler, Universities, 145, 147-48; Grendler, Jesuits and Italian Universities, 171-72.

197 Grendler, Jesuits and Italian Universities, 169-70.

198 Ratio studiorum, paragraph 230, p. 106.

199 Grendler, Jesuits and Italian Universities, 181-82. This was not a complete departure from Italian university practice. It was a common practice, sometimes mandated by university statutes, for professors and students to dispute informally in the piazza after a lecture.
} 
The Jesuits who taught theology and philosophy in the university gained the right to participate in examinations of candidates for doctorates of theology and philosophy. In Italian universities, colleges of doctors of theology consisting of clergymen possessing doctorates of theology examined a candidate and decided if he merited a degree. They were independent from universities and their membership consisted exclusively of Dominicans, Franciscans, Augustinians, and members of other medieval orders. When the new orders of the Catholic Reformation (Barnabites, Jesuits, Somaschans, and Theatines) appeared in the sixteenth century, Italian colleges of doctors of theology did not accept them into their ranks. ${ }^{200}$ However, Duke Ranuccio I and his successors promulgated new statutes that added Jesuits, but not members from other Catholic Reformation religious orders, to the Parma college of doctors of theology. Hence, Parma Jesuits, who constituted about a third of the membership of the college, were permitted to serve as promoters and examiners of theology degree candidates. ${ }^{201}$

The Jesuits did not get everything they wished. Antonio Possevino (15331611), who conducted the final negotiations for the Jesuits before the university began, wanted university statutes designed to make Parma a well-behaved Catholic university. It was an open secret that northern European Protestants came to study law and medicine in Italian universities while the authorities turned a blind eye so long as they did not engage in anti-Catholic acts. So, Possevino asked Duke Ranuccio I to bar heretics from enrolling. He further asked that students be forbidden from carrying arms. He wanted students who engaged in indecent behavior, wrote obscenities on walls, and played (unspecified) illicit games to be punished. He urged the duke to prevent students from shutting down lectures through noisy demonstrations or inventing vacation days, as often happened in Italian universities. However, the statutes issued by the duke did not bar heretics from attending or strip students of their swords. The reasons were obvious. If the duke had forbidden students to carry swords, they would not have come, and foreign students, even if they were heretics, brought prestige to the university and income to the town. ${ }^{202}$

So the University of Parma was a civic-Jesuit university in which the Jesuits comprised one-third of the faculty. They had a monopoly of instruction in theology, philosophy, mathematics, and rhetoric. Indeed, in some ways they had

200 For more on Italian colleges of doctors of theology, see Grendler, Universities, 357-66.

201 Grendler, Jesuits and Italian Universities, 176-78. It is likely that the Jesuits admitted into the Parma college of doctors of theology lacked doctorates, which was a remarkable break from tradition.

202 Grendler, Jesuits and Italian Universities, 161-64. 
their own arts and theology university within the larger law and medicine university. They had a significant role in the university, but not as important as in the University of Coimbra and other collegiate universities. The Jesuits taught in the University of Parma until they were expelled from the duchy of Parma and Piacenza on the night of February 7/8, 1768. The University of Parma exists today as a state university.

In 1625, Duke Ferdinando Gonzaga (1587-1626, regent 1613, duke 1616-26), ruler of the duchies of Mantua and Monferrato, created the civic-Jesuit Peaceful University of Mantua (Pacifico Gymnasio Mantuano), modeled on the University of Parma. Duke Ferdinando made a contract with the Jesuits, obtained imperial and papal charters, and hired distinguished law and medicine professors. The university began teaching in November 1625; it had more professors and classes, and was more innovative, than the University of Parma. In the academic year 1627-28, the Peaceful University of Mantua had thirty-seven professors who delivered forty-two lectures. The Jesuits provided ten professors who delivered twelve daily lectures in Scholastic theology, cases of conscience, scripture, metaphysics, natural philosophy, logic, moral philosophy, mathematics, and the humanities. Hence, the Jesuits provided slightly more than one-fourth of the professors and lectures. All the Jesuits taught without concurrents. ${ }^{203}$

War destroyed the Peaceful University of Mantua. The deaths of Duke Ferdinando in 1626 and Duke Vincenzo II Gonzaga in 1627 (1594-1627, r.162627), both without legitimate heirs, produced a dynastic crisis. Two claimants emerged, one supported by France and the other supported by the Habsburgs of Austria and Spain. In the ensuing War of the Mantuan Succession (1628-31), an Austrian Habsburg army laid siege to Mantua. Worse, soldiers or refugees brought the plague, which killed many thousands. Mantua fell to the Austrian army, which sacked Mantua for three terrible days, July 18-20, 1630, and stayed for another fourteen months. Although the Jesuits sent most of their teachers and scholastics out of the city, fifteen Mantua Jesuits died of disease from late 1629 through 1631. So did the Peaceful University of Mantua, which stopped teaching in the autumn of 1629 . Efforts to revive the university at the end of the seventeenth century and again in the eighteenth century came to little. ${ }^{204}$ Mantua has no university today.

The University of Fermo was a civic-Jesuit university in which the Jesuit role was smaller than at Parma and Mantua. Fermo, a small city in the papal

203 Grendler, University of Mantua. For a much condensed version of the story, see Grendler, Jesuits and Italian Universities, 189-223.

204 Grendler, University of Mantua, 227-50; Grendler, Jesuits and Italian Universities, 204-23. 
state, is located in the hills of central Italy about seven kilometers inland from the Adriatic Sea. Fermo wanted a university and got it when a local boy made good. Pope Sixtus V (Felice Peretti, 1521-90, r.1585-90) came from a nearby village, was cardinal archbishop of Fermo from 1571 to 1577 , and remembered the city fondly. In 1585, he issued a bull creating the University of Fermo. The city and the then cardinal archbishop of Fermo brought in the Jesuits in 1605 and inserted them into the university in $1609 .{ }^{205}$

The Jesuit part of the university was smaller than in Parma and Mantua. The University of Fermo had about twenty professors in the eighteenth century: ten in law, four in medicine, three in theology, and one each in logic, natural philosophy, and metaphysics. The Jesuits filled all three philosophy positions, but only one in theology. Thus, the Jesuits monopolized instruction in philosophy but had to compete in theology. The Fermo Jesuits did secure the right to participate in the promotion and examination of candidates for degrees in philosophy and theology. 206

But the city would not give the Jesuits more. Around 1700, the Jesuits offered to govern and improve a city-owned residence designed to attract foreign university students that had little success. The city, possibly incorrectly, saw this as a move toward controlling the entire university and sharply rebuffed the Jesuits. In addition, over time the city reduced its payment to the Jesuits for their teaching. The University of Fermo was suppressed in $1826 .{ }^{207}$

The Jesuits were also part of the University of Macerata, located in another small city in the hills of the papal state in central Italy. In 1540 and 1541, the city founded a small university of ten to twelve professors. When the Jesuits arrived in 1561, they lent two of their number to teach the humanities in the university until 1563 , and the Jesuits filled the logic position in the University of Macerata from 1612 to 1628 . Then, in 1639, the city and the Jesuits contracted for the Jesuits to fill the four positions of Scholastic theology, metaphysics, natural philosophy, and logic. When the city reduced its payment in 1645, the Jesuits stopped teaching theology in the university. They still monopolized the teaching of metaphysics, natural philosophy, and logic in the university, except for a handful of years when a medieval-order friar taught one of the courses, until 1773. They filled three professorships of the fifteen in the university and

205 Grendler, Jesuits and Italian Universities, 224-28. The contract in which the city agreed to pay the Jesuits for their university teaching was signed on March 23, 1609. But it is unclear if they began their university teaching in 1609 or 1611 .

206 Grendler, Jesuits and Italian Universities, 228-30.

207 Grendler, Jesuits and Italian Universities, 230-41. 
participated in the promotion and examination of degree candidates. Today, the University of Macerata is a state university best known for law instruction. ${ }^{208}$

\section{$7 \quad$ Jesuit Universities}

Next came Jesuit universities. With the approval and support of civil authorities, the Jesuits founded new universities in which the Society ruled the entire university. They were small collegiate universities in which the Jesuit school teaching the humanities, philosophy, and theology might be the entire university. Or it might include two or three professors of law and medicine. Nevertheless, the institution possessed a university charter from emperor, pope, or both, conferring on it the title, rights, and privileges of a university, including the right to award degrees including the doctorate.

Most important, the Society governed the entire university. That is, Jesuits had complete authority including the power to appoint professors and the chancellor, who conferred degrees. The rector of the local Jesuit college normally ruled a Jesuit university and might be chancellor as well. A Jesuit university was hard to distinguish from an ordinary Jesuit school except for the power to confer degrees including in law and medicine based on a university charter issued by a pope or emperor. Hence, observers probably perceived a Jesuit university to be more prestigious than an ordinary Jesuit upper school. And it is possible that a degree was more help in securing a civil position than study but no degree from a Jesuit school.

The University of Dillingen was a Jesuit university. In 1549, Cardinal Otto Truchsess von Waldburg (1514-73), the prince-bishop of Augsburg, founded a boarding school to educate diocesan clergy. In 1553, he obtained from Pope Julius III and Emperor Charles V (1500-58, r.1519-56) university charters awarding it the rights and privileges enjoyed by the universities of Paris and Bologna including the power to confer degrees. This was the standard grandiose language of university charters, but in reality Dillingen was still a boarding school for diocesan clergy. Seeking to improve it, Cardinal Truchsess, who was much impressed by Peter Canisius, invited the Jesuits to come to Dillingen to teach in and govern the University of Dillingen. After substantial negotiations especially concerning finances, the Jesuits came and took control of the university in 1564. Under Jesuit direction, the University of Dillingen grew to five hundred to six hundred students in the 1580 s. $^{209}$ At this time, it did not teach law or medicine.

208 Grendler, Jesuits and Italian Universities, 242-53.

209 Duhr, Geschichte, 1:194-200, 610-11; vol. 2, part 1:568-77; Broderick, Canisius, 351, 567-77, 615, 649, 766-67; Hengst, Jesuiten an Universitäten, 168-80, 299-302; William V. Bangert 
The small University of Dillingen is important because it disregarded the Jesuit Constitutions and Ignatius of Loyola. In 1625, it created a professorship of canon law and appointed a Jesuit, Paul Laymann (1574-1635), to fill it.210 This contradicted the Jesuit Constitutions, which barred Jesuits from teaching canon law. But it had not been a popular prohibition. From the 1560 s onward, some Jesuits and parents of students had wanted the Jesuits to teach canon law, but Generals Mercurian and Acquaviva had said no. So a few Jesuit boarding schools that believed that their students needed some canon law instruction made special arrangements. For example, beginning in 1586 the German-Hungarian College in Rome arranged for a secular priest with a doctorate in law to come and lecture on canon law to the boarders for an hour four times a week. ${ }^{211}$

The University of Dillingen canon law professorship was the result of the joint efforts of Heinrich von Knöringen (1570-1646, r.1599-1646), the prince-bishop of Augsburg who ruled Dillingen, and the local Jesuits. Knöringen, who had studied with the Jesuits in Dillingen and at the German-Hungarian College in Rome, was a strong supporter of the university. He obtained papal permission for the professorship, and the Dillingen Jesuits persuaded a reluctant superior general Muzio Vitelleschi (1563-1645, in office 1615-45) to approve it. Laymann, who published many works in moral theology and canon law, was the most influential Jesuit moral theologian of his time. He advised church and state authorities on legal issues surrounding the Thirty Years' War, always adopting a militant Catholic position. He taught until 1632 when the university closed temporarily because of Protestant military actions. In 1629, the university appointed a layman, the first to teach at the University of Dillingen, to teach civil law. Then in 1637 the university appointed another Jesuit, Christoph Schorrer $(1603-78)$, to the canon law professorship, which he held until $1643 .{ }^{212}$ Schorrer, who had obtained a bachelor's degree from Dillingen, also published works in moral theology and canon law, and rose to become assistant for Germany and vicar general of the Society. He was followed by additional Jesuits teaching canon law at the University of Dillingen. And the university continued to teach civil law. But it never taught medicine.

Other Jesuit universities and a few schools followed Dillingen's example. By the 169os, twelve Jesuit universities and schools in northern Europe and two

and Thomas M. McCoog, Jerome Nadal, S.J. Tracking the First Generation of Jesuits (Chicago: Loyola University Press, 1992), 143-44, 320-21; and Haub, "From Peter to Paul," 162-65.

210 Duhr, Geschichte, vol. 2, part 1:571. For the biography of Laymann, see Robert L. Bireley, "Laymann, Paul," DHCJ, 3:2297-98.

211 Grendler, Jesuits and Italian Universities, 323-24.

212 Duhr, Geschichte, vol. 2, part 1:568-74. For Schorrer, see Robert S. Gerlich, "Schorrer, Christoph," DHCJ, 4:3530. 
in Italy were teaching canon law. ${ }^{213}$ At the Fourteenth General Congregation (November 16, 1696, to January 16, 1697), the delegates endorsed the teaching of canon law and encouraged provincial superiors to establish canon law professorships in the major schools in their provinces. The congregation offered two reasons: many schools were already teaching canon law, and canon law supported positive theology. ${ }^{214}$ Nevertheless, the Fourteenth General Congregation was careful to repeat the prohibition of the Constitutions: Jesuits should not teach the parts of canon law useful in litigation. ${ }^{215}$ The Sixteenth General Congregation (November 19, 1730, to February 13, 1731) removed this prohibition by authorizing Jesuits to teach all parts of canon law. ${ }^{216}$ Hence, more Jesuit universities and schools taught it. ${ }^{217}$ Canon law was the only disciplinary breach of the university part of the Constitutions. So far as can be discovered, no Jesuit taught civil law or medicine in a Jesuit school in Europe before the suppressions.

Pont-à-Mousson in the independent duchy of Lorraine offers another example of a Jesuit university. Cardinal Charles de Lorraine (1524-74) asked the Jesuits to found a university there, while his brother, the duke of Lorraine, promised strong financial support. Superior General Borja agreed, and Pope Gregory XIII issued a university charter in December 1572. Then came a two-year delay caused by the death of Borja, the election of a new superior general, and the search for Jesuit personnel for the university. The Jesuits arrived in Pont-à-Mousson and inaugurated the university with a few classes in October $1574 .{ }^{218}$

The university grew. The Jesuits steadily added professorships of philosophy, Scholastic theology, cases of conscience, and scripture. A class in law began in 1577, followed by medicine, both taught by non-Jesuits. The number of Jesuits - teachers and scholastics — reached nearly a hundred in the 1590s. The student body grew to 1,60o in the Jesuit school and four hundred students of law and medicine in 1605 . As stipulated by the papal bull, the rector of the Jesuit school governed the university and filled the position of chancellor, while the

213 Grendler, Jesuits and Italian Universities, 323-38.

214 Catholic positive theology relies on scripture; the writings of the church fathers; decrees of ecumenical councils, popes, and synods; the works of theologians; tradition; history; and canon law to explain God's plan for humans. By contrast, speculative theology seeks to understand the nature of God and his message for humans through philosophical and theoretical investigation. Of course, the two are not mutually exclusive.

215 Padberg, O'Keefe, and McCarthy, For Matters of Greater Moment, 368, decree 20.

216 Padberg, O'Keefe, and McCarthy, For Matters of Greater Moment, 383, decree 30.

217 Grendler, Jesuits and Italian Universities, 338-39.

218 Fouqueray, Histoire, 1:604-15; 2:2-8; Pierre Delattre, "Pont-à-Mousson. Université," in Les établissements en France, 4:79-88; and Martin, "Jesuit Mission to France," 265-66. 
deans of the faculties of law and medicine served under him. The legists were unhappy and wanted the faculty of law to have its own chancellor, in effect, to become independent of the Jesuits. But the papacy refused to change the charter. The University of Pont-à-Mousson continued through the Thirty Years' War and years of French occupation (1641-48, 1670-97, and various times between 1701 and 1714 ) but closed at the suppression. ${ }^{219}$

Other Jesuit universities founded in the late sixteenth and seventeenth centuries included Bamberg, Graz, Molsheim in Alsace, which moved to Strasbourg in 1681, Osnabrück, and Paderborn in German-speaking lands. ${ }^{220}$ Tournon was a French Jesuit university until $1626 .{ }^{221}$ The Jesuit University of Olomouc (or Olmütz) in modern-day Czech Republic began in 1573 as a philosophy and theology university; law was added in 1679, although the Jesuits viewed it as unnecessary. ${ }^{222}$ The Jesuit University of Breslau (or Wrocław) in Lower Silesia (now part of Poland) began in 1702 and taught only philosophy and theology. ${ }^{223}$ The universities of Cagliari and Sassari in Sardinia, which was ruled by the Kingdom of Aragon until 1718 and the duchy of Piedmont-Savoy afterward, were thriving Jesuit universities, as was Évora in Portugal. ${ }^{224}$

219 Fouqueray, Histoire, 4:228-30; and Delattre, "Pont-à-Mousson. Université," 4:97-161.

220 For these universities, see Duhr, Geschichte, 1:133-43, 163-69; vol. 2, part 1:164-69, 18790, 553-58, 586-88, 590-95; and the relevant pages in Hengst, Jesuiten an Universitäten, 184-99, 205-36, 288-94. In addition, for Graz see Heiss, "Educational Politics," 178-86; for Molsheim, see Simona Negruzzo, L'armonia contesa: Identità ed educazione nell'Alsazia moderna (Bologna: Il Mulino, 2005), 99-128, 183-230 and passim; and for Paderborn, see Johannes Sander, Geschichte des Jesuitenkollegs in Paderborn 1580-1659, Textedition und Übersetzung von Gerhard Ludwig Kneissler, mit Anmerkungen versehen von Friedrich Gerhard Hohmann (Paderborn: Bonifatius, 2011).

221 In 1561, the Jesuits were given control of the Collège Cardinal de Tournon, which was raised to a university by Pope Julius III and French King Henry II (1519-59, r.1547-59) in 1552 . Hence, it became the Jesuit University of Tournon, which taught arts and theology. However, a coalition of other French universities and parlements persuaded the Parlement of Toulouse to withdraw university status in 1626. Fouqueray, Histoire, 1:288-303; 4:36-49; and Pierre Delattre, "Le Collège Cardinal de Tournon," in Les établissements en France, 4:1408, 1414-16, 1428 .

222 For a brief introduction and substantial bibliography, see David Papajík, "The Development of Olomouc University from 1573 to the Present," History of Universities 27, no. 2 (2013): 146-54.

223 Carsten Rabe, Alma Mater Leopoldina: Kolleg und Universität der Jesuiten in Breslau 16381837 (Cologne: Böhlau, 1999).

224 At that time in Sardinia, the local language was Sard and the language of the educated was Spanish. There is much bibliography; start with Raimondo Turtas, La nascita dell'università in Sardegna: La politica culturale dei sovrani spagnoli nella formazione degli Atenei di Sassari e di Cagliari (1543-1632) (Sassari: Dipartimento di Storia, Università degli Studi di Sassari, 1988); and Le origini dello Studio generale sassarese nel mondo 
In 1579, the Jesuits founded the Jesuit University of Vilnius in the PolishLithuanian Commonwealth (formally the Crown of the Kingdom of Poland and the Grand Duchy of Lithuania) with charters from the king of Poland and Pope Gregory XIII. The University of Vilnius was important to the Jesuits, because the University of Kraków (permanent foundation in 1400) prevented the Jesuits in Kraków from teaching external students (see below "Universities Warring against Jesuit Schools"). The University of Vilnius added canon and civil law in 1645, but never taught medicine before the suppression. ${ }^{225}$

\section{$8 \quad$ Universities with Individual Jesuit Professors}

A small number of universities appointed individual Jesuits to teach without according the Society an institutional position in the university. This happened because the university or the civil government wanted the learned expertise of a Jesuit. Or it was a personal appointment that was the result of excellent scholarship and friendship. When an individual Jesuit professor was judged to have discharged his duties well, other Jesuits might follow him into the university. But these were also individual appointments that did not lead to the Society obtaining an institutional or contractual role in the university.

The University of Ferrara presented an example. The duchy of Ferrara had multiple water management problems because of the Po River, which regularly flooded, the Reno River, and the water-soaked Comácchio marsh near the Adriatic Sea. A Jesuit had been advising Ferrara on water issues on an intermittent basis for a number of years. Then in 1675 , Francesco Lana Terzi (1631-87), an able Jesuit mathematician, was appointed to fill the sole professorship of mathematics at the University of Ferrara. In addition to teaching the university mathematics curriculum, which was very similar to the mathematics curriculum of the Ratio studiorum, he was charged with training men in water management and dike construction. The city subsequently added new duties: anyone who wished to earn accreditation as an expert in hydraulics was obliged to attend the lectures of Lana Terzi who would lecture in Italian. A skilled and versatile mathematician, Lana Terzi was a major improvement over his lay predecessor, a generalist with limited expertise. Lana Terzi filled the position until 1679. After a layman taught for nine years, four more Jesuits filled the professorship of mathematics from 1688 until 1771, and advised the

universitario europeo dell'età moderna, sotto la direzione di Gian Paolo Brizzi, Antonello Mattone (Bologna: CLUEB, 2013). For the University of Évora, see Rodrigues, História, vol. 1, part 1:578-85; vol. 1, part 2:303-35; and Sáinz de Zúñiga, Historia de las universidades hispánicas, 2:117-21; 3:343-44.

225 Rabikauskas, "Lituania," DHCJ, 3:2387-89, 2391-93. 
duchy. Critics who protested that the Jesuit professors were insufficiently loyal to Ferrara because they were members of a religious order whose superiors were in Rome were ignored. ${ }^{226}$

The University of Pavia, located thirty-five kilometers south of Milan, also appointed a Jesuit to its sole professorship of mathematics, which led to additional Jesuits teaching in the university. The appointment came because the Jesuit was both a distinguished scholar and a friend of prominent Milanese senators. Girolamo Saccheri (1667-1733) as a young Jesuit studied philosophy, mathematics, and theology at the Jesuit school in Milan, at which time he published a book that solved a number of geometry problems. His accomplishments and the recommendation of his Jesuit teacher gained him entry into an academy of Milanese noblemen where he met prominent senators with scientific and mathematical interests. Saccheri then taught philosophy at the Jesuit school in Turin (which was part of the Jesuit province of Milan) and published in 1697 a logical work that was far in advance of current scholarship. Next came a fortuitous set of circumstances possibly aided by strategic planning. In that same year of 1697 , the professor of mathematics at the University of Pavia died, while the Jesuit provincial leadership moved Saccheri to Pavia to teach philosophy in the Jesuit school there. Then in January 1699 the Senate of Milan, which ruled the University of Pavia, appointed Saccheri to the vacant mathematics professorship at the University of Pavia. ${ }^{227}$

Saccheri taught mathematics at the University of Pavia from 1699 until his death and published a book on Aristotelian statics and a study on non-Euclidian geometry that anticipated future developments. In addition to his lectures, Saccheri represented the city of Pavia in a meeting to discuss a hydraulics project involving the Po River. Several other Jesuit mathematicians followed Saccheri to the University of Pavia. One was Bošković, who held the position from 1764 to 1768 . And three more Jesuits - two humanists and a theologian-were appointed to professorships at the University of Pavia. However, as at the University of Ferrara, the Society did not win an institutional place in the university. ${ }^{228}$

Although Jesuits were appointed to professorships because they were able scholars and friends of senators, birthplace and social class also brought them

226 Grendler, Jesuits and Italian Universities, 370-76. On Lana Terzi, see Mario Zanfredini, "Lana-Terzi, Francesco," $D H C J$, 3:2275-76; and Alessandra Fiocca, "Galileiani e gesuiti a Ferrara nel Seicento," in Galileo e la scuola galileiana nelle università del Seicento, ed. Luigi Pepe (Bologna: CLUEB, 2011), 292-309, here 302-5.

227 Grendler, Jesuits and Italian Universities, 376-80; and Saverio Corradino, "Saccheri, Giovanni Girolamo," DHCJ, 4:3457-58.

228 Grendler, Jesuits and Italian Universities, 380-82. 
to universities. At this point in time, a large number of the lay professors at the University of Pavia were sons of prominent families of Pavia, Milan, and the rest of Lombardy. So were many Jesuits including most of those who taught at the University of Pavia. Jesuits born in Milan or Pavia, who studied at the Jesuit school in Milan, taught in Jesuit schools in Lombardy, and enjoyed the friendship of Milanese senators, were not outsiders. ${ }^{229}$

Another example comes from the University of Siena. Giuseppe Ferroni (Pistoia 1628-1709 Siena), a Jesuit mathematician, then teaching at the Jesuit school in Bologna, wrote to friends at the Medici court in Florence, which ruled Siena. Having taught mathematics in distant places for twenty-five years, Ferroni wished to return to his native Tuscany. He asked his friends to get him the professorship of mathematics at the University of Siena. They delivered, and Ferroni began to teach at the university in 1686. Although there was some local opposition on the grounds that this was the opening move of the Jesuits to take over the university, Ferroni assured critics that he was not appointed because he was a Jesuit. He taught at the university until he died. Two more Jesuits, another mathematician and a geographer, also taught at the University of Siena in the eighteenth century. Again both were personal appointments. ${ }^{230}$

The individual appointments at the universities of Ferrara, Pavia, Siena, and elsewhere document significant developments. By the late seventeenth century and especially in the eighteenth, some universities were willing to appoint individual Jesuits without giving the Society an institutional role. And the Society accepted this. The Jesuits did not make demands on the universities, even though they preferred an institutional role. The appointments also demonstrate that some Jesuits, especially those with mathematical and scientific expertise, were now part of Enlightenment Europe, at a time when opposition to the religious mission of the Jesuits and to organized religion generally was growing.

\section{$9 \quad$ The Jesuits and Spanish Universities}

The situation in Spain was both similar and different from the rest of Europe. Spanish universities were collegiate universities that, unlike Paris, were not implacably hostile toward the Jesuits. Hence, the Society established colleges with schools in Spanish university towns and attempted to have the Jesuit college made a constituent part of the university. Or it tried to persuade universities

229 Grendler, Jesuits and Italian Universities, 383.

230 Grendler, Jesuits and Italian Universities, 311-12, 389-91. For Ferroni, see Maurizio Torrini, "Giuseppe Ferroni, gesuita e galileiano," Physis 15 (1973): 411-23; and Mario Zanfredini, "Ferroni, Giuseppe," $D H C J$, 2:1411. 
to insert Jesuit courses, mostly theology lectures, into the university curriculum. Some opposition came from secular colleges on the grounds that this was contrary to university statutes, and from members of the medieval mendicant orders such as the Dominicans, who were strong in Spanish universities. However, by the seventeenth century the Spanish Jesuits were known for their excellent teaching and scholarship, and they enjoyed the support of civic and ecclesiastical authorities. Hence, Spanish universities permitted a few Jesuits to fill university professorships. Or a university incorporated the theology lectures of the local Jesuit school into its curriculum, as Alcalá de Henares and Salamanca did. ${ }^{231}$ But Jesuit colleges were not incorporated into Spanish universities, or permitted to dominate arts instruction, as was the case at the University of Coimbra.

Thus, Spanish Jesuits achieved some of their university goals. And they did so despite intense theological controversies. The largest was the de auxiliis controversy, the debate concerning the relative roles of God's grace and human free will in man's action, in which Dominican theologians opposed Jesuit theologians. It began in the 1580 s in the Netherlands and continued in Rome and in Spain, because the most important writers on the issue were Spanish Jesuits and Spanish Dominicans who lived and taught at Alcalá de Henares, Salamanca, and Valladolid. Although Pope Paulv (1550-1621, r.1605-21) ordered a halt to new publications on the controversy in 1611, it continued in other works. This was followed by the controversy over probabilism, which also pitted Spanish Dominicans against Spanish Jesuits. ${ }^{232}$

However, Spain did not want Jesuit universities, that is, universities ruled by the Society. A high-profile attempt to create a Jesuit university in Madrid produced a backlash from two prestigious universities. In 1623, King Philip IV of Spain (1605-65, r.1621-65), in association with Madrid Jesuits, decided to create the Colegio Imperial de Madrid. This would be a royal university teaching the humanities, philosophy, science, and theology. It was conceived as a larger version of the Collège Royal in Paris (today called the Collège de France). The planned professorships were Greek; Hebrew; Chaldean (a version of Aramaic, the language of Jesus) and Syriac; history; logic; two in natural philosophy; metaphysics; two in mathematics; Aristotelian ethics; politics and economics; Polybius (ancient Greek historian of Rome) and the De re militari of Vegetius (late fourth-century Roman); animals, plants, stones, and minerals; moral theology and cases of conscience; and scripture. Jesuits would govern and do all

231 Sáinz de Zúñiga, Historia de las universidades hispánicas, 2:54, 56-57, 351; and 3:153, 167, 178-79, 185, 205-6, 254, 256, 268, 273-74, 290, 299-300, 316-17.

232 Astrain, Historia, 4:115-385, and 6:119-240. 
the teaching in the Colegio Imperial. It would be a Jesuit university that would confer degrees. ${ }^{233}$

The universities of Salamanca and Alcalá de Henares-the latter located only thirty kilometers east of Madrid — were furious. They objected that they would be ruined, because students would flock to the Colegio Imperial. They also argued that a university should not be given to a single religious order. The University of Salamanca retaliated by forbidding the Jesuits of Salamanca from teaching or engaging in any other academic exercises on its premises. After several years of charges and lawsuits, the king and the Society retreated. They agreed that the Colegio Imperial would not teach logic, which was practically a required university course, nor award university degrees. In other words, the Colegio would be a school, not a university. The Colegio Imperial began to teach in 1629. Although a number of able Jesuit scholars taught there, it did not fulfil the expectations of the Society or the king. It became just "an ordinary college of the Society of Jesus." ${ }^{234}$

The University of Douai in the Spanish Netherlands was a collegiate university that played a special role in the Catholic Reformation and CounterReformation. And the Jesuit college was the largest unit in the university. 35 King Philip II of Spain created the University of Douai. He obtained a papal university charter in 1559, issued his own letters patent in 1561, and provided the financial support that enabled Douai to begin teaching in 1562 . The University of Douai had five faculties: arts, theology, canon law, civil law, and medicine. Most of the students lived and studied in the three founding arts colleges: the royal college sponsored by Philip II, and two others with religious foundations. Smaller religious order colleges were added later.

The Jesuits arrived in 1568 . They were given direction of one of the non-royal colleges, which almost immediately enrolled more students than the other two founding colleges combined. The Jesuits taught the humanities, philosophy, and theology in their school. The faculty of arts, which represented the interests of the regent masters and professors in the other colleges, which charged fees, objected to the free philosophy instruction of the Jesuits. After intense negotiations, an agreement was reached. The Jesuits were permitted to teach

\footnotetext{
233 Astrain, Historia, 5:139-53; and José Martínez de la Escalera, "Colegio Imperial de Madrid," DHCJ, 1:844-45.

234 "Un colegio ordinario de la Compañía de Jesús." Astrain, Historia, 5:153-70, quote at 169; Escalera, "Colegio Imperial de Madrid," 844-45.

235 For this and the following two paragraphs, see Poncelet, Histoire, 1:179-97, 315-20, 33-40; 2:30-31, 164-87; Hugues Beylard, "Douai. Le Collège d'Anchin (1568-1764)," in Les établissements en France, 2:173-262; and Sáinz y Zúñiga, Las universidades hispanicas, 2:189-202; 3:446-49.
} 
philosophy without charge. Hence, they became the philosophy lecturers for the entire university and received limited funding from the university. In exchange, the Jesuits waived their right to confer degrees and to examination fees, which went to regent masters and non-Jesuit professors. The Jesuits also operated a boarding school in partnership with an abbot and some lay teachers. In 1575, the Jesuits taught about six hundred students in their school plus another four hundred in the boarding school. Because of a shortage of Jesuits and other issues, the Society withdrew from the boarding school in 1576 , and it immediately declined precipitously.

The University of Douai was unique because it was the intellectual center of English Catholicism in exile for two centuries. So many influential English Catholics were administrators, teachers, and students in Douai that it looked like a Catholic Oxford. Douai scholars prepared the Douay-Rheims English translation of the Bible, which was published in 1582, 1609, and 1610, and much additional religious scholarship. The university was the center of the effort to restore Catholicism to the British Isles. Douai had an English college (founded 1568), a Scots college (founded 1608), and an Irish college (founded 1613) preparing seminarians who returned to their native lands as secular priest missionaries. About 160 of them were martyred. The Jesuits directed the Scots college and Irish college whose students studied in the Jesuit school. The Jesuits did not direct the English college, although its students attended the Jesuit school for a number of years, while a Jesuit served as spiritual director for some years. ${ }^{236}$ France seized Douai in 1677 , and in 1887 the University of Douai was moved to Lille, twenty-seven kilometers away, where it became the University of Lille.

\section{$10 \quad$ Universities Warring against Jesuit Schools}

The oldest and most prestigious universities were the most hostile toward the Jesuits, primarily because Jesuit schools were effective competitors. The universities of Paris, Bologna, and Padua went to war against the Jesuits, while Kraków, the most important university in eastern Europe, kept out the Jesuits.

The University of Paris engaged in what one historian called a hundred years' war against the Jesuits. ${ }^{237} \mathrm{He}$ was wrong by half: the war lasted two hundred years and the university won.

236 Hugues Beylard, "Douai: Le Séminaire Écossais," in Les établissements en France, 2:262-69; and Hugues Beylard and Pierre Delattre, "Douai: Le Collège des Grands Anglais," in Les établissements en France, 2:269-71.

237 James Brodrick, The Progress of the Jesuits (1556-79) (New York: Longmans, Green and Co., 1947), 32 . 
The Jesuits came to Paris, established their college called the Collège de Clermont, and began teaching in 1564 . It became a major educational presence in Paris when Juan Maldonado (1533-83) taught theology in the Jesuit school from 1565 to 1569 and from 1570 through 1574 . As many as three hundred students came to his lectures. Buoyed by Maldonado's popularity and that of other Jesuit teachers, the Jesuits asked that the Collège de Clermont be incorporated into the University of Paris. ${ }^{238}$

This was an audacious request. Paris was the largest and most important collegiate university in Europe and it had a complex structure. It differed from many other collegiate universities in two significant ways: religious orders did not control any colleges within the university, and no single college dominated humanities and philosophy instruction. The vast majority of the students studied the humanities and philosophy in order to obtain one or more of bachelor, licentiate, and master of arts degrees. However, they did not matriculate in the university corporation, although they did register with one of the student nations. Instead, they found a master to teach them in one of about forty secular colleges that comprised the university. ${ }^{239}$ Students boarded and studied in these colleges, or lived elsewhere but came to the college for classes. In either case, the students paid fees to the secular college, which enabled the college to pay the salaries and board of their professors and regent masters. The students were a mix of lay boys and men, secular clergymen, and would-be clergymen.240

Several hundred members of medieval mendicant orders (Augustinians, Dominicans, Franciscans, etc.) also studied in Paris. However, they were excluded from the secular college path to arts degrees as a consequence of rules imposed by the university in the Middle Ages when it feared domination by the friars. So members of the regular clergy studied in their own convent schools, or they lived in their own convents while studying in a secular college, paying the necessary fees. The orders, which had the power of awarding degrees, conferred arts degrees on those it deemed worthy. ${ }^{241}$

238 Fouqueray, Histoire, 1:363-433; Pierre Delattre, "Paris: Le Collège," in Les établissements en France, 3:1103-14; and Philippe Lécrivain, "The Struggle for Paris: Juan Maldonado in France," in Mercurian Project, 295-321.

239 These are often called colleges de plein exercice, that is, colleges teaching a complete curriculum, meaning the humanities and Aristotelian philosophy, which always included logic and natural philosophy, and usually some metaphysics, moral philosophy, and mathematics.

240 James K. Farge, Orthodoxy and Reform in Early Reformation France: The Faculty of Theology of Paris, 1500-1543 (Leiden: Brill, 1985), 11-12; for the medieval history of the secular colleges of Paris, see A. [Alan] B. Cobban, The Medieval Universities: Their Development and Organization (London: Methuen, 1975), 84-86, 122-32.

241 Cobban, Medieval Universities, 91-94; Farge, Orthodoxy and Reform, 11-12. 
After obtaining the bachelor of arts, licentiate of arts, and/or master of arts, a minority of students remained in Paris in order to study for degrees in theology, medicine, or canon law. And new students with arts degrees from elsewhere arrived for the same purpose. Students in the higher faculties were free to attend lectures in any of the colleges and convents in Paris. Indeed, when they were in Paris the first Jesuits had attended theology lectures by various Dominicans and Franciscans who lectured in their own convents. ${ }^{242}$ Now many students were attending the gratis and unrestricted lectures of Maldonado in the Jesuit Collège de Clermont. So the Jesuits asked that their college be incorporated into the university.

If granted, this would give significant benefits to the Jesuits and their students. The Clermont College would be permitted to teach the humanities and philosophy to students preparing for the arts degrees examinations, while individual Jesuits might be invited to join the faculty of theology. Inclusion would be university recognition for the instruction that they were already offering and would enable the Jesuits to teach more students and help more souls. Because of the prestige and influence of Paris and its faculty of theology, inclusion would give the Society greater national and international visibility. And there was alumni nostalgia. The Jesuits wanted to be part of the university that had played an essential role in the formation of the Society and its pedagogy. The Jesuits had the support of some local clergymen, and in 1574, Pope Gregory XIII issued a brief endorsing their incorporation into the university. ${ }^{243}$ In order to overcome the university's prohibition against religious orders, the Jesuits argued that they were not mendicant order friars, but clerics regular and, thus, more like secular clergymen than mendicant order friars. ${ }^{244}$

The answer was a resounding "no" from different parts of the University of Paris in 1573 and 1574. The university rejected the argument that clerics regular were different from mendicant friars. The faculty of arts went further by forbidding all university students from attending lectures in the Jesuit school, and all Jesuit students from attending classes in the rest of the university. The

242 Farge, Orthodoxy and Reform, 13-28; Grendler, Jesuits and Italian Universities, 26-27 and especially note 47 .

243 Fouqueray, Histoire, 1:363-433; Delattre, "Paris," 1115-18; Lécrivain, "Struggle for Paris," $300-3,310-15$.

244 The Jesuits, and almost all other Catholic Reformation orders (Theatines, Barnabites, Somaschans, Piarists, et al.), were clerics regular, a canonical designation introduced in the sixteenth century. Clerics regular focused on ministries in the world, such as teaching, rather than prayer and contemplation. They were not tied to a monastery but freer to move from place to place. They were not obliged to say prayers at set hours of the day, and their vows were somewhat different from those of friars. Nevertheless, they still were members of religious orders bound by vows of poverty, chastity, and obedience. 
university declared that it would not confer licentiates and doctorates on students who had previously studied at the Clermont College. The intention was a complete separation of the Jesuits and their students from the university. The motivation went beyond reiterating the prohibition excluding religious order colleges from the university. The Jesuits were teaching for free and effectively the same curriculum as the secular colleges. And the university and the Parlement of Paris saw the Jesuits as papal agents undermining Gallicanism, that is, the concessions wrung from the papacy that permitted the king to rule the French church practically free of papal intervention. The request for incorporation into the university was a tactical error. ${ }^{245}$

Despite the university's hostility, the Paris Jesuit school taught eleven classes including Scholastic theology to about 1,500 students in the 1580 os. $^{246}$ Moreover, the prohibition against conferring degrees on former students of the Jesuits was not rigorously enforced during the climax of the French Wars of Religion in the late 1580 s and early 1590 , when some members of the university and some Jesuits made common cause in opposing Henry of Navarre becoming King Henry IV of France. ${ }^{247}$ Then, as described above, the Jesuits were expelled from Paris in 1594.

Although the Jesuits returned in 1605, the university with the support of the Parlement of Paris fought long and hard to prevent the Collège de Clermont from teaching again. Only thanks to royal action was it permitted to teach theology in 1609 and all disciplines in 1618 . At the same time, the university took action to stop small secular colleges from sending some of their students to classes at the Clermont College. That is, some small secular colleges lacking skilled teachers for their philosophy courses had been sending their students to the Jesuit school. They then returned to their home colleges to pass degree examinations. Because these students were enrolled in secular colleges, they remained university students when attending Jesuit classes. The university tried to stop the practice but apparently did not succeed. The university also tried to reduce the number of the small secular colleges, also without success. ${ }^{248}$

And so it went for the rest of the seventeenth and the eighteenth centuries. So far as can be determined, none of the university measures against the Jesuit college was ever rescinded. Nevertheless, the Clermont school expanded

245 Piaget, Histoire, 91-92; Fouqueray, Histoire, 1:551-52, 581-82; Delattre, "Paris," 1115-18; André Tuilier, Histoire de l'Université de Paris et de La Sorbonne, 2 vols. (Paris: Nouvelle Librairie de France, 1994), 1:386-88, 395, 405-10.

246 Delattre, "Paris," 1121.

247 Piaget, Jésuites en France, 156-57.

248 Fouqueray, Histoire, 5:241-48; Delattre, "Paris," 1137-42; Tuilier, Université de Paris, 1: 475$76,483,496-97$. 
greatly. In the late 166os, it enrolled 2,500 to three thousand students, including four hundred to five hundred boarders, some of them from beyond France. ${ }^{249}$ Such a large enrollment suggests that students may have found ways to work around the university actions against the Jesuit school. At the same time, accusations that the Jesuits were disloyal subjects because they were insufficiently Gallican continued. And when Jansenists joined the university, they also attacked the Jesuits. In 1682, the Paris Jesuits made the prudential move of renaming its college the Collège Louis le Grand in order to secure the protection of Louis XIV. ${ }^{250}$ This did not save the Paris Jesuits from being expelled at the French suppression of 1762 . When this happened, the university landed a final blow: it forbade the secular colleges from accepting any man who had been a Jesuit in $1761 .{ }^{251}$ Although the Jesuit school in Paris taught thousands of students in two centuries, the University of Paris triumphed over it.

The University of Bologna, founded in the second half of the twelfth century, vied with Paris for the honor of being the first European university. The Jesuits arrived in Bologna in 1536 and founded a lower school of three classes in 1551. But they did not teach philosophy and theology until the 1630s, at which time members of the university viewed the Jesuit upper school as an illegal competitor. Some members of the university and their supporters in the city government demanded that the Jesuits be barred from teaching theology and philosophy on the grounds that the university had the exclusive right to teach these subjects. Although the Jesuits never tried to enter the university, they wanted to teach theology and philosophy in their own school. This led to prolonged quarreling, albeit without dramatic confrontations. After several lengthy disputes, the university, the city government, the papacy (which ultimately ruled Bologna because it was part of the papal state), and the Jesuits reached a de facto compromise in the 1670 . It permitted the Society to teach theology, metaphysics, natural philosophy, logic, and mathematics to Jesuit scholastics and qualified students enrolled in the two local Jesuit boarding schools, but to no one else. As a consequence, enrollment in the Jesuit upper school was about 140, a number far below upper-school enrollments in other Italian cities. ${ }^{252}$

The University of Padua, founded in 1222, succeeded in closing the local Jesuit school. The Jesuits founded a school in Padua in 1552, whose humanities, logic, and natural philosophy classes competed well with the university by

249 Delattre, "Paris," 1142.

250 Tuilier, Université de Paris, 2:78.

251 Tuilier, Université de Paris, 2:165.

252 For the story, see Grendler, Jesuits and Italian Universities, 282-318. 
the 1580 os. $^{253}$ Professors and some students went to the Venetian Senate, which ruled Padua, to denounce the Jesuit school as an illegal competitor to the university. In late December 1591, the Senate ordered the Jesuit school to stop teaching external students, thereby eliminating more than ninety-five percent of the enrollment. The Jesuits decided to close their school.

There was more to the Senate decision than defending the University of Padua from competition. The rise of an anti-papal party in the Senate, international tensions, and some maladroit Jesuit maneuvers convinced many Venetian nobles that Jesuit education produced disloyal subjects. Then a church-state jurisdictional dispute caused the papacy to issue an excommunication interdict against Venice in 1606. Venice ordered all religious orders within its borders to disobey the papacy. When the Jesuits refused, the Senate expelled them from the Republic of Venice and did not allow them to return until 1657. The Jesuits re-founded their school in Padua but were careful not to teach any upper-school classes. As at Bologna, the Jesuits never tried to enter the University of Padua. But hostility from the university, political events, and an anti-Jesuit ideology in the Venetian nobility caused the closure of Jesuit schools for a half century.

The University of Kraków (1364, ceased functioning in the 1370s, re-founded 1400), the leading university in the Polish-Lithuanian Commonwealth, also took action against the Jesuits. The Society founded a college and school for its own members in Kraków in 1622 and sought integration into the university; in 1628 , the Jesuits began to teach philosophy to external students. The university objected, arguing that the Jesuits damaged the university by offering unlawful competition in violation of the legal rights of the university, the same argument presented by the University of Bologna. The Jesuits appealed to the Sacred Roman Rota, the highest court in the Catholic Church, which endorsed the Jesuit classes. But a new king (Władysław IV Vasa [1595-1648, r.1632-1648]) took the side of the university. He obtained a brief from Pope Urban VIII in 1634 that ordered the Jesuits "for the love of peace" to stop teaching external students, while permitting them to teach theology to their own members. ${ }^{254}$ At Leuven (Louvain), the Jesuit college and school never became part of the University of Leuven. Quite the contrary, the Jesuit theologians and the university theologians engaged in polemics for nearly two centuries, especially over

253 For this and the next paragraph, see Grendler, Jesuits and Italian Universities, 115-53.

254 Ludwik Piechnik and Ludwik Grzebień, "Polonia," DHCJ, 4: 3176; Piotr Stolarski, Friars on the Frontier: Catholic Renewal and the Dominican Order in Southeastern Poland, 1594-1648 (Farnham: Ashgate, 2010), 28-41, 71-75; and Stolarski, "Dominican-Jesuit Rivalry and the Politics of Catholic Renewal in Poland 1564-1648," Journal of Ecclesiastical History 62 (2011): $255^{-72 .}$ 
Jansenism, which the university theologians often supported and the Jesuit theologians condemned. ${ }^{255}$ Thus, some famous universities barred the Jesuits from becoming part of the university, or restricted their enrollments, or forced the local Jesuit school to close.

\section{$11 \quad$ Jesuits and Universities: Conclusions}

The Jesuits played an extraordinary role in European university education from the 1550s to 1773. One scholar notes that twenty-one of the approximately twenty-two Catholic universities in Germany "were in some way connected with the Society of Jesus." 256 While the Jesuit impact was strongest in German-speaking Europe, Jesuits were part of some universities in every other Catholic territory in Europe.

Jesuit participation in universities took several forms. The most common model was the civic-Jesuit collegiate university. The civil authority, or the prince-bishop, who oversaw the local university gave the Society a statutory and contractually defined place in a collegiate university. That is, the Society governed and taught in an important unit in the university corporation. In an arts and theology collegiate university, this was typically the most important teaching college. In addition, the Jesuits often but not always dominated the faculty of theology. Typical civic-Jesuit collegiate universities were Coimbra, Mainz, Trier, and others in central Europe.

The civil rulers of four Italian law and medicine universities also granted Jesuits an institutional role in universities. The Society typically filled eight to ten professorships in the humanities, mathematics, logic, natural philosophy, metaphysics, and theology, one-fourth to one-third of the teaching positions in a large law and medicine university, but a smaller fraction in smaller law and medicine universities. The Jesuits had a significant but not dominant role in these universities, because the majority of students came to study law and medicine, and these disciplines dominated the university. The universities of Parma and Mantua were examples. The Jesuit place in Italian civic-Jesuit law and medicine universities was significant but not as important as in civicJesuit collegiate universities.

255 Jan Roegiers, "Awkward Neighbours: The Leuven Faculty of Theology and the Jesuit College (1542-1773)," in The Jesuits of the Low Countries: Identity and Impact (1540-1773), Proceedings of the International Congress at the Faculty of Theology and Religious Studies, Ku Leuven (3-5 December 2009) (Leuven: Peeters, 2012), 153-75, provides a succinct summary.

256 Müller, “'Universitas et Societas Jesu,'” 398. The exception was the Benedictine University of Salzburg founded in 1622 . 
The third model was the Jesuit university, an institution in which the Society ruled the whole university. They did all of the teaching in the humanities, philosophy, and theology. A Jesuit filled the office of rector and sometimes of chancellor. If the Jesuit university taught law and medicine, the instruction was very limited and also under the authority of the Jesuits. All Jesuit universities were new and small, in part because this was a new university form. Dillingen, Évora, and Tournon were examples.

Some well-established universities appointed individual Jesuits, especially mathematicians, to university positions because their expertise was valued. These were individual appointments; the Society was accorded no institutional place in the university. If the first Jesuit appointed made a favorable impression, other Jesuits might also be invited to teach. The universities of Ferrara, Pavia, and Siena in Italy, and several Spanish universities, were examples.

The oldest and most prestigious universities fought the Jesuits tooth and nail. They kept the Jesuits out, or shut down the local Jesuit school, or prevented the creation of rival Jesuit schools. The universities of Paris, Bologna, Padua, and Kraków successfully pursued this policy.

The Jesuits succeeded as university professors. It helped that some of the Jesuit professors in the Society's first seventy-five years were brilliant and prolific scholars and teachers. The Society was able to continue to provide university professors throughout Europe for the next two hundred years because the Society expanded greatly, and because the Jesuits continued to insist on very high educational and pedagogical standards for their priests.

Despite their excellence as teachers and scholars, there was more opposition to the Jesuits in universities than to Jesuit schools. The most important reasons were the most obvious: competition for positions and students. Every Jesuit professor teaching the humanities, mathematics, logic, natural philosophy, or theology meant one fewer non-Jesuit professor. Jesuit classes attracted students who otherwise would attend the classes of rival teachers, colleges, and universities. Ecclesiastical and theological differences also provoked opposition. Although French Jesuits swore allegiance to Gallicanism multiple times, the University of Paris, the Parlement of Paris, and many Frenchmen still saw the Jesuits as Rome's fifth column. In other lands, there was little ecclesiastical opposition and theological differences stayed within normal boundaries.

Catholic universities with Jesuit professors were more international in outlook than civil universities without Jesuits or Protestant universities. As members of an international religious order with a strong sense of mission who taught the same curriculum throughout Europe, the Jesuits personified a cosmopolitan Republic of Learning in which universities claimed membership. 


\section{Acknowledgment}

I wish to thank Robert A. Maryks for the invitation and his help on this essay.

\section{Bibliography}

\section{$1 \quad$ Primary Sources}

ARSI $=$ Archivum Romanum Societatis Iesu

Cambridge Translations of Renaissance Philosophical Texts, vol. 1, Moral Philosophy. Edited by Jill Kraye. Cambridge: Cambridge University Press, 1997.

The Constitutions of the Society of Jesus and Their Complementary Norms: A Complete English Translation of the Official Latin Texts. Edited by John W. Padberg. St. Louis: Institute of Jesuit Sources, 1996.

Epistolae et acta Patris Jacobi Lainii secundi praepositi generalis Societatis Iesu ex autographis vel originalibus exemplis potissimum deprompta a Patribus ejusdem Societatis edita, vol. 2, 1557. Edited by Ephrem Astudillo. Madrid: Typis Gabrielis López del Horno, 1912.

Fabrini, Natale. Un documento bolognese inedito su le scuole dei gesuiti. Rome: Stella Matutina, 1946.

For Matters of Greater Moment: The First Thirty Jesuit General Congregations; A Brief History and $a$ Translation of the Decrees. Edited and Translated by John W. Padberg, Martin D. O'Keefe, and John L. McCarthy. St. Louis: Institute of Jesuit Sources, 1994. Gorzoni, Giuseppe. Istoria del Collegio di Mantova della Compagnia di Giesù scritta dal padre Giuseppe Gorzoni: Parte prima. Edited by Antonella Bilotto and Flavio Rurale. Mantua: Gianluigi Arcari Editore, 1997.

Ignatius of Loyola. Letters and Instructions. Edited by Martin E. Palmer, John W. Padberg, and John L. McCarthy. St. Louis: Institute of Jesuit Sources, 2006.

Jesuit Pedagogy, 1540-1616: A Reader. Edited by Cristiano Casalini and Claude Pavur. Chestnut Hill, MA: Institute of Jesuit Sources, 2016.

Monumenta paedagogica Societatis Iesu. Nova editio ex integro refecta. Edited by László Lukács. 7 vols. Rome: Apud "Monumenta Historica Soc. Iesu," 1965-92 [henceforth Mon. paed., nova editio].

Sancti Ignatii de Loyola Societatis Jesu fundatoris epistolae et instructiones, vol. 3, 15501551. Edited by Vicente Agustí, Federico Cervós, and Mariano Lecina. Madrid: Gabrielis López del Horno, 1905.

Termanini, Tommaso. "Delle qualità che formano la perfezione propria dei maestri delle scole inferiori di questo Istituto." ARSI, Opp. NN., 459. 
Vita Ignatii Loiolae et rerum Societatis Iesu historia auctore Joanne Alphonso de Polanco ejusdam Societatis sacerdote, vol. 5, 1555. Edited by José M. Vélez. Madrid: Augustín Avrial, 1897.

Year by Year with the Early Jesuits (1537-1556): Selections from the Chronicon of Juan de Polanco S.J. Translated by John Patrick Donnelly. St. Louis: Institute of Jesuit Sources, 2004.

\section{$2 \quad$ Secondary Sources}

Alden, Dauril. The Making of an Enterprise: The Society of Jesus in Portugal, Its Empire, and Beyond 1540-1740. Stanford, CA: Stanford University Press, 1996.

Angelozzi, Giancarlo. "L'insegnamento dei casi di coscienza nella pratica educativa della Compagnia di Gesù." In La Ratio studiorum: Modelli culturali e pratiche educative dei gesuiti in Italia tra Cinque e Seicento. Edited by Gian Paolo Brizzi, 121-62. Rome: Bulzoni Editore, 1981.

Art, Controversy, and the Jesuits: The Imago primi saeculi (1640). Edited by John W. O'Malley. Philadelphia: Saint Joseph's University Press, 2015.

Astrain, Antonio. Historia de la Compañía de Jesús en la asistencia de España. Segunda edición. 7 vols. Madrid: Administración de Razón y Fe, 1912-25.

Bailly, Paul. "Collèges." In Les établissements des jésuites en France depuis quatre siècles: Répertoire topo-bibliographique publié à l'occasion du quatrième centenaire de la fondation de la Compagnie de Jésus, 1540-1940, sous la direction de Pierre Delattre, 1:1394-1503. 5 vols. Enghien: Institut supérieur de théologie, 1949-1957 [henceforth as Les établissements en France].

Bangert, William V., and Thomas M. McCoog. Jerome Nadal, S.J. 1507-1580: Tracking the First Generation of Jesuits. Chicago: Loyola University Press, 1992.

Baron, Hans. The Crisis of the Early Italian Renaissance: Civic Humanism and Republican Liberty in an Age of Classicism and Tyranny. Revised one-volume edition with an epilogue. Princeton: Princeton University Press, 1966.

Beylard, Hugues. "Douai: Le Collège d'Anchin (1568-1764)." In Les établissements en France, 2:173-262.

Beylard, Hugues. "Douai: Le Séminaire Écossais." In Les établissements en France, 2:262-69.

Beylard, Hugues, and Pierre Delattre. "Douai: Le Collège des Grands Anglais." In Les établissements en France, 2:269-71.

Bireley, Robert L. The Jesuits and the Thirty Years War: Kings, Courts, and Confessors. Cambridge: Cambridge University Press, 2003.

Bireley, Robert L. "Laymann, Paul." In Diccionario histórico de la Compañía de Jesús: Biográfico-temático. Edited by Charles E. O’Neill and Joaquín M. ${ }^{a}$ Domínguez, 3:2297-99. 4 vols. Rome and Madrid: Institutum Historicum S.I. and Universidad Pontificia Comillas, 2001 [henceforth $\mathrm{DHCJ}$ ]. 
Bireley, Robert L. Religion and Politics in the Age of the Counterreformation: Emperor Ferdinand II, William Lamormaini, S.J., and the Formation of Imperial Policy. Chapel Hill, NC: University of North Carolina Press, 1981.

Bottereau, Georges. "Jouvancy (Juvencius), Joseph de." DHсJ, 3:2157-58.

Braga, Theophilo. História da Universidade de Coimbra nas suas relações com a instrucção publica portugueza. 2 vols. Lisbon: Typographia da Academia Real das Sciencias, 1892-95.

Brandão, Mário, and M. Lopes D’Almeida. A Universidade de Coimbra: Esboço da sua história. Coimbra: Por ordem da Universidade, 1937.

Brizzi, Gian Paolo. La formazione della classe dirigente nel Sei-Settecento: I seminaria nobilium nell'Italia centro-settentrionale. Bologna: Il Mulino, 1976.

Brizzi, Gian Paolo. "La scolarité de Pietro Antonio Adami chez les jésuites à la fin du xvii ${ }^{\mathrm{e}}$ siècle." Histoire de l'éducation 124 (2009): 51-71.

Brockey, Liam Matthew. The Visitor: André Palmeiro and the Jesuits in Asia. Cambridge, MA: Harvard University Press, 2014.

Brodrick, James. The Progress of the Jesuits (1556-79). New York, London, and Toronto: Longmans, Green and Co., 1947.

Brodrick, James. Saint Peter Canisius. Chicago: Loyola Press, 1998 [1935].

Burson, Jeffrey D. "Between Power and Enlightenment: The Cultural and Intellectual Context for the Jesuit Suppression in France." In The Jesuit Suppression in Global Context: Causes, Events, and Consequences, edited by Jeffrey D. Burson and Jonathan Wright, 40-64. Cambridge: Cambridge University Press, 2015.

The Cambridge Encyclopedia of the Jesuits. General Editor Thomas Worcester. Cambridge: Cambridge University Press, 2017.

Capasso, Gaetano. "Il Collegio dei Nobili di Parma: Memorie storiche pubblicate nel terzo centenario dalla sua fondazione (28 ottobre 1901)." Archivio storico per le provincie parmensi, n.s., 1 (1901): 1-285.

Casalini, Cristiano. Aristotele a Coimbra: Il Cursus conimbricensis e l'educazione nel Collegium Artium. Rome: Anicia, 2012.

Casalini, Cristiano. Aristotle in Coimbra: The Cursus Conimbricensis and the Education at the College of Arts. Translated by Luana Salvarani. Abingdon and New York: Routledge, 2017.

Cesareo, Francesco C. "The Jesuit Colleges in Rome under Everard Mercurian." In The Mercurian Project: Forming Jesuit Culture 1573-1580, edited by Thomas M. McCoog, 607-44. Rome and St. Louis: Institutum Historicum Societatis Iesu and Institute of Jesuit Sources, 2004.

Clavel, Pierre. "Oratorio di Gesù e di Maria Immacolata." In Dizionario degli istituti di perfezione. Edited by Guerrino Pelliccia and Giancarlo Rocca, 6:776-80. 10 vols. Rome: Edizioni Paoline, 1974-2003 [henceforth DIP].

Cobban, A. [Alan] B. The Medieval Universities: Their Development and Organization. London: Methuen \& Co., 1975. 
Il Collegio dei nobili di Parma: La formazione della classe dirigente (secoli XVII-XIX). Atti del Convegno nazionale, Fornovo, Sala Baganza, Fontevivo, 22-24 maggio 2008, a cura di Alba Mora. Parma: Monte Università Parma Editore, 2013.

Corish, Patrick J. "The Beginning of the Irish College, Rome." In The Irish College, Rome, and Its World, edited by Dáire Keogh and Albert McDonnell, 1-13. Dublin: Four Courts Press, 2008.

Corradino, Saverio. "Saccheri, Giovanni Girolamo." DHCJ, 4:3457-58.

Dainville, François de. L'éducation des jésuites (XVI ${ }^{e}-X V I I I^{e}$ siècles). Textes réunis et présentés par Marie-Madeleine Compère. Paris: Les Éditions de Minuit, 1978.

Dall'isola alla città: I gesuiti a Bologna. A cura di Gian Paolo Brizzi e Anna Maria Matteucci. Bologna: Nuova Alfa Editoriale, 1988.

De Viguerie, Jean. Une oeuvre d'éducation sous l'ancien régime: Les Pères de la doctrine chrétienne en France et en Italie 1592-1792. Paris: Les Éditions de la Nouvelle Aurore, 1976.

Delattre, Pierre. "Le Collège Cardinal de Tournon." In Les établissements en France, 4:1407-35.

Delattre, Pierre. “Introduction.” In Les établissements en France, 1:i-Xvi.

Delattre, Pierre. “Paris. Le Collège." In Les établissements en France, 3:1101-1258.

Delattre, Pierre. "Pont-à-Mousson." In Les établissements en France, 4:79-161.

Delattre, Pierre. "Pontoise." In Les établissements en France, 4:195-271.

Delattre, Pierre. "Séminaires." In Les établissements en France, 4:1051-78.

Diccionario histórico de la Compañia de Jesús: Biográfico-temático. Edited by

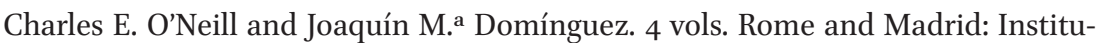
tum Historicum S.I. and Universidad Pontificia Comillas, 2001 [henceforth $D H C J$ ].

Dilworth, Mark. "Beginnings 1600-1707." In The Scots College Rome 1600-200o, edited by Raymond McCluskey, 19-42. Edinburgh: John Donald, 2000.

Dizionario degli istituti di perfezione. Edited by Guerrino Pelliccia and Giancarlo Rocca. 10 vols. Rome: Edizioni Paoline, 1974-2003 [henceforth DIP].

Donnelly, John Patrick. “Auger, Émond.” $D H C J, 1: 268-69$.

Donnelly, John Patrick. "Hoffaeus, Paul." DHCJ, 2:1932-33.

Duclos, Paul. "Francia." DHCJ, 2:1498-1516.

Duhr, Bernhard. Geschichte der Jesuiten in den Ländern deutscher Zunge. 4 vols. in 6 parts. Freiburg im Breisgau: Herder, 1907-28.

Echarte, Ignacio. "Casas." DHCJ, 1:678-87.

Elorduy, Eleuterio. "Suárez, Francisco." $D H C J, 4: 3654-56$.

Encyclopedia of the Renaissance. General Editor Paul F. Grendler. 6 vols. New York: Charles Scribner's Sons, 1999.

Les établissements des jésuites en France depuis quatre siècles: Répertoire topo-bibliographique publié à l'occasion du quatrième centenaire de la fondation de la Compagnie de Jésus, 1540-1940, sous la direction de Pierre Delattre. 5 vols. Enghien: Institut supérieur de théologie, 1949-57. 
Farge, James K. Orthodoxy and Reform in Early Reformation France: The Faculty of Theology of Paris, 1500-1543. Leiden: Brill, 1985.

Farge, James K. "Paris, University of." In Encyclopedia of the Renaissance, 4:403-6.

Farrell, Allan P. The Jesuit Code of Liberal Education:Development and Scope of the Ratio studiorum. Milwaukee: Bruce Publishing Company, 1938.

Fink, Urban. "Diego Laínez, das Collegium Germanicum und die Priesterausbildung zur Zeit des Trienter Konzils." In Diego Laínez (1512-1565) and His Generalate: Jesuit with Jewish Roots, Close Confidant of Ignatius of Loyola, Preeminent Theologian of the Council of Trent, edited by Paul Oberholzer, 819-36. Bibliotheca Insitituti Historici S.I. Rome: Institutum Historicum Societatis Iesu, 2015.

Fiocca, Alessandra. "Galileiani e Gesuiti a Ferrara nel Seicento." In Galileo e la scuola galileiana nelle università del Seicento, edited by Luigi Pepe, 293-309. Bologna: CLUEB, 2011.

Fois, Mario. "Aquaviva, Claudio." DHCJ, 2:1614-21.

Fois, Mario. "Il Collegio Romano: L'istituzione, la struttura, il primo secolo di vita." Roma moderna e contemporanea 3, no. 3 (1995): 571-99.

Fois, Mario. "Vitelleschi, Mucio [Muzio]." DHcJ. 2:1621-27.

Fouqueray, Henri. Histoire de la Compagnie de Jésus en France des origines à la suppression (1528-1762). 5 vols. Paris: Bureaux des Études, 1910-25.

Freedman, Joseph S. "Philosophy Instruction within the Institutional Framework of Central European Schools and Universities during the Reformation Era." History of Universities 5 (1985): 117-66.

Friedrich, Markus. Die Jesuiten: Aufstieg Niedergang Neubeginn. Munich: Piper, 2016.

Frijhoff, Willem. "Patterns." In A History of the University in Europe, vol. 2, Universities in Early Modern Europe (1500-180o), edited by Hilde de Ridder-Symoens, 43-110. Cambridge: Cambridge University Press, 1996.

García Villoslada, Ricardo. Sant'Ignazio di Loyola. Traduzione dallo spagnolo di Anna Maria Ercoles. Milan: Edizioni Paoline, 1990.

Gerlich, Robert S. "Chequia." $D H C J, 1: 760-67$.

Gerlich, Robert S. "Schorrer, Christoph." DHCJ, 4:3530.

Grendler, Paul F. "The Culture of the Jesuit Teacher 1548-1773." Journal of Jesuit Studies 3, no. 1 (2016): 17-41.

Grendler, Paul F. The Jesuits and Italian Universities 1548-1773. Washington, DC: Catholic University of America Press, 2017.

Grendler, Paul F. Schooling in Renaissance Italy: Literacy and Learning, 1300-1600. Baltimore: Johns Hopkins University Press, 1989.

Grendler, Paul F. “Universities.” In Encyclopedia of the Renaissance, 6:189-93. General Editor Paul F. Grendler. 6 vols. New York: Charles Scribner's Sons, 1999. 
Grendler, Paul F. The Universities of the Italian Renaissance. Baltimore: Johns Hopkins University Press, 2002.

Grendler, Paul F. The University of Mantua, the Gonzaga \& the Jesuits, 1584-1630. Baltimore: Johns Hopkins University Press, 2009.

Hamy, Alfred. Documents pour servir a l'histoire des domiciles de la Compagnie de Jésus dans le monde entier de 1540 a 1773. Paris: Alphonse Picard, 1892.

Haub, Rita. "From Peter to Paul: The Province of Upper Germany in the 1570s." In The Mercurian Project: Forming Jesuit Culture 1573-1580, edited by Thomas M. McCoog, 145-81. Rome and St. Louis: Institutum Historicum Societatis Iesu and Institute of Jesuit Sources, 2004.

Heiss, Gernot. "Educational Politics in the Austrian Lands and the Foundation of the Jesuit University of Graz, 1585." In European Universities in the Age of Reformation and Counter Reformation, edited by Helga Robinson-Hammerstein, 169-86. Dublin: Four Courts Press, 1998.

Hengst, Karl.Jesuiten an Universitäten und Jesuitenuniversitäten. Paderborn: Ferdinand Schöningh, 1981.

Hermans, Alphonse-Maurice. "Fratelli delle Scuole Cristiane." DIP, 4:729-46.

Hermans, Alphonse-Maurice. "Giovanni Battista de la Salle." DIP , 4:1237-43.

Huppert, George. Public Schools in Renaissance France. Urbana, IL: University of Illinois Press, 1984.

The Jesuit Suppression in Global Context: Causes, Events, and Consequences. Edited by Jeffrey D. Burson and Jonathan Wright. Cambridge: Cambridge University Press, 2015 .

Join-Lambert, Michel. "Bérulle, Pierre de." DIP, 1:1407-9.

Kádár, Zsófia. "The Difficulties of Conversion (of) Non-Catholic Students in Jesuit Colleges in Western Hungary in the First Half of the Seventeenth Century." Hungarian Historical Review 3, no. 4 (2014). http://hunghist.org/archive/83-articles/277-201 4-4-kadar (accessed July 4, 2018).

Koláĉek, Josef. "Colegio San Clemente de Praga.” DHCJ, 1:852-53.

Korade, Miko. "Colegio Ilírico de Loreto." $D H C J$, 1:843-44.

Korade, Miko, and Bogumil Remec, "Croacia y Slovenia." DHCJ, 2:1006-10.

Krajcar, Jan. "Colegio Griego, Roma." DHCJ, 1:842-43.

Kraus, Andreas. Das Gymnasium der Jesuiten zu München (1559-1773): Staatspolitische, Sozialgeschichtliche, Behördengeschichtliche und Kulturgeschichtliche Bedeutung. Munich: Verlag C. H. Beck, 2001.

Kučinskis. "Letonia y Estonia." DHCJ, 3:2338-40.

Lécrivain, Philippe. "The Struggle for Paris: Juan Maldonado in France." In The Mercurian Project: Forming Jesuit Culture 1573-1580, edited by Thomas M. McCoog, 295-321. 
Rome and St. Louis: Institutum Historicum Societatis Iesu and Institute of Jesuit Sources, 2004.

Lisson, Edwin, Eduardo Moore, and James T. Bretzke. “Teología: V. Moral.” DHCJ, 4:3739-45.

Martin, A. Lynn. "The Jesuit Mission in France." In The Mercurian Project: Forming Jesuit Culture 1573-1580, edited by Thomas M. McCoog, 249-93. Rome and St. Louis: Institutum Historicum Societatis Iesu and Institute of Jesuit Sources, 2004.

Mazin, Paul. "La Flèche." In Les établissements en France, 2:904-19.

McCabe, William H. An Introduction to the Jesuit Theater: A Posthumous Work. Edited by Louis J. Oldani. St. Louis: Institute of Jesuit Sources, 1983.

McMillan, James F. "Development 1707-1820." In The Scots College Rome 16oo-2000, 43-66. Edinburgh: John Donald, 2000.

The Mercurian Project: Forming Jesuit Culture 1573-1580. Edited by Thomas M. McCoog. Rome and St. Louis: Institutum Historicum Societatis Iesu and Institute of Jesuit Sources, 2004.

Methuen, Erich. Die alte Universität. Kölner Universitätsgeschichte Bd. 1. Cologne and Vienna: Böhlau, 1988.

Methuen, Erich. "A Brief History of the University of Cologne." www.portal.uni-koeln .de/universitaetsgeschichte.html? \&L=1 (accessed July 4, 2018).

Mobley, Susan Spruell. “The Jesuits at the University of Ingolstadt.” In The Mercurian Project: Forming Jesuit Culture 1573-1580, edited by Thomas M. McCoog, 213-48. Rome and St. Louis: Institutum Historicum Societatis Iesu and Institute of Jesuit Sources, 2004.

Moore, Eduardo. "Casos de conciencia." DHCJ, 1:6991-94.

Moore, Eduardo. “Teología: V.2. Casuismo." DHCJ, 4:3747-48.

Mousnier, Roland. The Assassination of Henry IV: The Tyrannicide Problem and the Consolidation of the French Absolute Monarchy in the Early Seventeenth Century. Translated by Joan Spencer. New York: Charles Scribner's Sons, 1973.

Müller, Rainer A. “'Universitas et Societas Iesu': The Catholic Universities in Early Modern Germany." In Università in Europa: Le istituzioni universitarie del Medio Evo ai nostri giorni; Strutture, organizzazione, funzionamento. Atti del Convegno Internazionale di Studi. Milazzo 28 settembre-2 ottobre 1993, a cura di Antonella Romano, 395-403. Messina: Rubbettino Editore, 1995.

Negruzzo, Simona. L'armonia contesa: Identità ed educazione nell'Alsazia moderna. Bologna: Il Mulino, 2005.

Negruzzo, Simona. Collegij a forma di Seminario: Il sistema diformazione teologica nello Stato di Milano in età spagnola. Brescia: Editrice La Scuola, 2001.

Nelson, Eric. The Jesuits and the Monarchy: Catholic Reform and Political Authority in France (1590-1615). Aldershot, Burlington, VT, and Rome: Ashgate and Institutum Historicum Societatis Iesu, 2005 . 
Niedźwiedź, Jakub. "Jesuit Education in the Polish-Lithuanian Commonwealth $\left(1565^{-}\right.$ 1773)," Journal of Jesuit Studies 5, no. 3 (2018): 441-55.

Novarese, Daniela. Istituzioni politiche e studi di diritto fra Cinque e Seicento: Il Messanense Studium Generale tra politica gesuitica e istanze egemoniche cittadine. Milan: A. Giuffrè Editore, 1994.

O'Connell, Patricia. The Irish College at Santiago de Compostela 1605-1769. Dublin: Four Courts Press, 2007.

O'Malley, John W. The First Jesuits. Cambridge, MA: Harvard University Press, 1993.

O'Malley, John W. "From the 1599 Ratio studiorum to the Present: A Humanistic Tradition?" In The Jesuit Ratio studiorum: 4ooth Anniversary Perspectives, edited by Vincent J. Duminuco, 127-44. New York: Fordham University Press, 2000.

Le origini dello Studio generale sassarese nel mondo universitario europeo dell'età moderna. Sotto la direzione di Gian Paolo Brizzi, Antonello Mattone. Bologna: CLUEB, 2013.

Padberg, John W. "Development of the Ratio studiorum." In The Jesuit Ratio studiorum: 40oth Anniversary Perspectives, edited by Vincent J. Duminuco, 80-100. New York: Fordham University Press, 2000.

Il palazzo degli studi: Appunti per una storia dell'istruzione superiore a Mantova; Luoghi e vicende dal Collegio dei gesuiti al Liceo Ginnasio "Virgilio". Edited by Ugo Bazzotti and Daniela Ferrari. 2nd ed. Mantua: Publi-Paolini Editore, 1998.

Papajík, David. "The Development of Olomouc University from 1573 to the Present." History of Universities 27, no. 2 (2013): 146-66.

Pastor, Ludwig von. The History of the Popes from the Close of the Middle Ages. Translated by F. I. [Frederick Ignatius] Antrobus et al. 40 vols. London and St. Louis: Herder, 1891-1953.

I patrimoni dei gesuiti nell'Italia moderna: Una prospettiva comparativa. A cura di Niccolò Guasti. Bari: Edipuglia, 2013.

Pavone, Sabina. "I gesuiti in Italia (1548-1773)." In Atlante della letteratura italiana, vol. 2, Dalla Controriforma alla Restaurazione, a cura di Erminia Irace, 359-73. Turin: Einaudi, 2011.

Perry, Mary Elizabeth, "El legado de Francisco de Borja en las escuelas para niños moriscos." In Francisco de Borja y su tiempo: Política, religión y cultura en la edad moderna, edited by Enrique García Hernán and María del Pilar Ryan, 6o9-17. Valencia and Rome: Albatros Ediciones and Institutum Historicum Societatis Iesu, 2011.

Piaget, Édouard. Histoire de l'établissements des jésuites en France (1540-1640). Leiden: E. J. Brill, 1893 .

Piechnik, Ludwik, and Ludwik Grzebień, "Polonia." DHCJ, 4:3173-87.

Pierrefeu, Guy de. "Aubenas," in Delattre, Les établissements des jésuites en France, 1:365-73.

Platzgummer, Helmut. "Parhamer (Parhammer), Ignaz." DHCJ, 3:3044-45. 
Poggi, Vincenzo. “Collegio Maronita." DHCJ, 1:846-48.

Poncelet, Alfred. Histoire de la Compagnie de Jésus dans les anciens Pays-Bas: Établissement de la Compagnie de Jésus en Belgique et ses développements jusqu’à la fin du règne d'Albert et d'Isabelle. 2 vols. Brussels: Académie royale de Belgique, 1927-28.

Poutet, Yves. "Fratelli della Scuole Cristiane e di Carità." DIP, 4:746-47.

Rabe, Carsten. Alma Mater Leopoldina: Kolleg und Universität der Jesuiten in Breslau 1638-1811. Cologne: Böhlau Verlag, 1999.

Rabikauskas, Paulius. "Lituania." DHCJ, 3:2386-95.

Rista, Carlo. "Bus, César de." DIP, 1:1681-83.

Rista, Carlo. "Dottrinari di Avignone." DIP , 3:975-77.

Rodrigues, Francisco. História da Companhia de Jesus na assistência de Portugal. 4 vols. in 7 parts. Porto: Apostolado da Imprensa, 1931-50.

Roegiers, Jan. "Awkward Neighbors: The Leuven Faculty of Theology and the Jesuit College (1542-1773)." In The Jesuits of the Low Countries: Identity and Impact (1540-1773), 153-75. Proceedings of the International Congress at the Faculty of Theology and Religious Studies Ku Leuven (3-5 December 2009). Leuven: Peeters, 2012.

Rurale, Flavio. I gesuiti a Milano: Religione e politica nel secondo Cinquecento. Rome: Bulzoni Editore, 1992.

Rzegocka, Jolanta. "Civic Education on Stage: Civic Values and Virtues in the Jesuit Schools of the Polish-Lithuanian Commonwealth." In Exploring Jesuit Distinctiveness: Interdisciplinary Perspectives on Ways of Proceeding within the Society of Jesus, edited by Robert Aleksander Maryks, 41-61. Leiden: Brill, 2016.

Sander, Johannes. Geschichte des Jesuitenkollegs in Paderborn 1580-1659. Textedition und Übersetzung von Gerhard Ludwig Kneissler. Mit Anmerkungen versehen von Friedrich Gerhard Hohmann. Paderborn: Bonifatius, 2011.

Scaduto, Mario. Storia della Compagnia di Gesù in Italia, vol. 3, L'epoca di Giacomo Lainez, 1556-1565: Il governo, vol. 4, L'epoca di Giacomo Lainez, 1556-1565: L'azione, vol. 5, L'opera di Francesco Borgia, 1565-1572. Rome: La Civiltà Cattolica, 1964, 1974, 1992. Schmidt, Peter. Das Collegium Germanicum in Rom und die Germaniker: Zur Funktion eines römischen Ausländerseminars (1552-1914). Tübingen: Max Niemeyer, 1984.

Schmidt, Siegfried. "Das Gymnasium Tricoronatum unter der Regentschaft der Kölner Jesuiten." In Die Anfänge der Gesellschaft Jesu und das erste Jesuitenkolleg in Köln, 71-186. Cologne: Erzbischöfliche Diözesan- und Dombibliothek, 2006.

Shore, Paul. The Eagle and the Cross: Jesuits in Late Baroque Prague. St. Louis: Institute of Jesuit Sources, 2002.

Shore, Paul.Jesuits and the Politics of Religious Pluralism in Eighteenth-Century Transylvania: Culture, Politics, and Religion, 1693-1773. Aldershot, Burlington, VT, and Rome: Ashgate and Institutum Historicum Societatis Iesu, 2007.

Shore, Paul. Narratives of Diversity: Jesuits on the Eastern Peripheries of the Habsburg Realms (1640-1773). Budapest and New York: Central European University Press, 2012. 
Silva Gonçalves, Nuno da. "Jesuits in Portugal." In The Mercurian Project: Forming Jesuit Culture 1573-1580, edited by Thomas M. McCoog, 705-44. Rome and St. Louis: Institutum Historicum Societatis Iesu and Institute of Jesuit Sources, 2004.

Sirignano, Fabrizio Manuel. "Il teatro dei gesuiti: Un esperimento di educazione del cittadino tra il 1500 e il 1600 in Europa." In Annali: Rivista di Ateneo 20og, 223-31. Naples: Università degli Studi Suor Orsola Benincasa, 2009.

Stegmüller, Friedrich. Filosofia e teologia nas Universidades de Coimbra e Évora no século XVI. Coimbra: Universidade de Coimbra, 1959.

Stolarski, Piotr. "Dominican-Jesuit Rivalry and the Politics of Catholic Renewal in Poland 1564-1648." Journal of Ecclesiastical History 62 (2011): 255-72.

Stolarski, Piotr. Friars on the Frontier: Catholic Renewal and the Dominican Order in Southeastern Poland, 1594-1648. Farnham and Burlington, VT: Ashgate, 2010.

Strilič, Ivan. "Boškovič, Ruđer [Ruggero], Josip." DHCJ, 1:499-500.

Szilas, László. "Austria. Antigua." DHCJ, 1:277-92.

Tacchi Venturi, Pietro. Storia della Compagnia di Gesù in Italia. 2 vols. in 4 parts. Rome: Civiltà Cattolica, 1910-1951.

Thompson, D. Gillian. "French Jesuits 1756-1814." In The Jesuit Suppression in Global Context: Causes, Events, and Consequences, edited by Jeffrey D. Burson and Jonathan Wright, 181-98. Cambridge: Cambridge University Press, 2015.

Torrini, Maurizio. “Giuseppe Ferroni, gesuita e galileiano." Physis 15 (1973): 411-23.

Tuilier, André. Histoire de l'Université de Paris et de La Sorbonne. 2 vols. Paris: Nouvelle Librairie de France, 1994.

Turrini, Miriam. La coscienza e le leggi: Morale e diritto nei testi per la confessione della prima Età moderna. Bologna, il Mulino, 1991.

Turrini, Miriam. Il "giovine signore" in collegio: I gesuiti e l'educazione della nobiltà nella consuetudini del collegio ducale di Parma. Bologna: CLUE B, 2006.

Turtas, Raimondo. La nascita dell'università in Sardegna: La culturale dei sovrani spagnoli nella formazione degli Atenei di Sassari e di Cagliari (1543-1632). Sassari: Dipartimento di Storia, Università degli Studi, 1988.

Van Kley, Dale. The Jansenists and the Expulsion of the Jesuits from France 1757-1765. New Haven: Yale University Press, 1975.

Van Kley, Dale. "Plots and Rumors of Plots: The Role of Conspiracy in the International Campaign against the Society of Jesus, 1758-1768." In The Jesuit Suppression in Global Context: Causes, Events, and Consequences, edited by Jeffrey D. Burson and Jonathan Wright, 13-39. Cambridge: Cambridge University Press, 2015.

Vasconcelos, António de. Os colégios universitários de Coimbra. Coimbra: Coimbra Editora, 1938.

Velinkar, Joseph. "Jesuit Educational Style in Sixteenth Century Goa." Diryadaan 13, no. 1 (2002): 59-72.

Villoslada, Ricardo G. Storia del Collegio Romano dal suo inizio (1551) alla soppressione della Compagnia di Gesù (1773). Rome: Apud Aedes Universitatis Gregorianae, 1954. 
Williams, Michael E. “Colegio Inglés de Roma.” DHCJ 1:845-46.

Williams, Michael E. St. Alban's College Valladolid: Four Centuries of English Catholic Presence in Spain. London: Hurst, 1986.

Williams, Michael E. The Venerable English College Rome: A History. 2nd ed. Leominster: Gracewing, 2008.

Zanfredini, Mario. “Ferroni, Giuseppe." DHCJ, 2:1411.

Zanfredini, Mario. "Lana-Terzi, Francesco." DHCJ, 3:2275-76.

Zanfredini, Mario. “Termanini, Tommaso." DHCJ, 4:3779.

Zúñiga, Sáinz de, and Cándido María Ajo González de Rapariegos. Historia de las universidades hispánicas, vol. 2, El siglo de oro universitario. Ávila: Senén, 1958; and vol. 3, Periodo de los pequeños Austrias. Madrid: Artes Gráficas C. I. M., 1959. 